

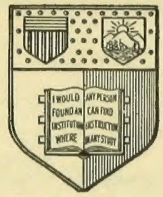

\section{New York}

State College of Agriculture At Cornell University Ithaca, N. Y.

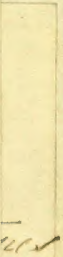

Library

QL 542.888 1834

v.2

The book of butterflies, sphinges, and $m$

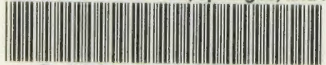

31924018266894 


\section{Date Due}

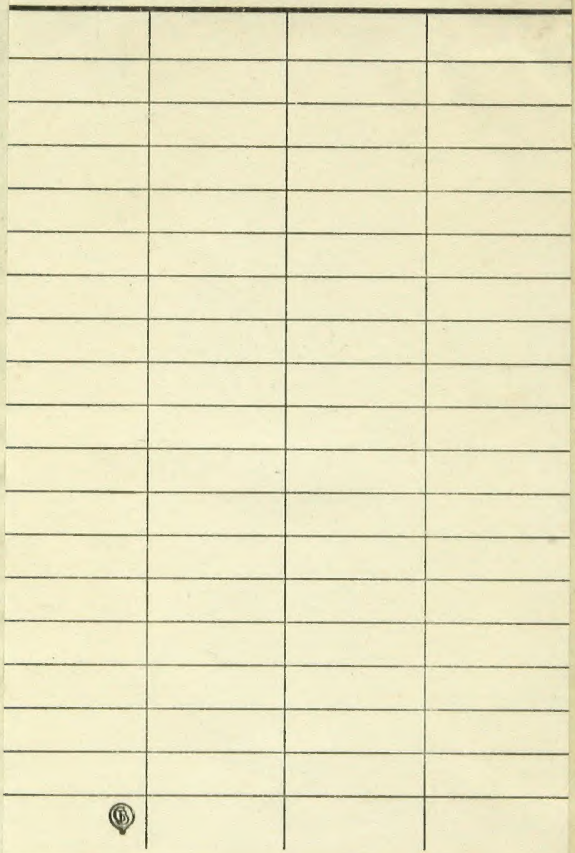


THE

\title{
BOOK OF BUTTERFLIES,
}

\author{
SPHINGES, AND MOTHS.
}


EDINBURGH:

PAINTED BY M. AITKEN, 1, ST JAMF'S EUUARK. 


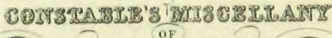

Arigimal amosolectio |jublicationts

IN THE VARIOUS DEPARTMENTS

IITTERATURE, SCIENCE \& THE ARTS.

VOI. IXXYI.

THE BOOK OF BUTTERFLIES. VOL. II.

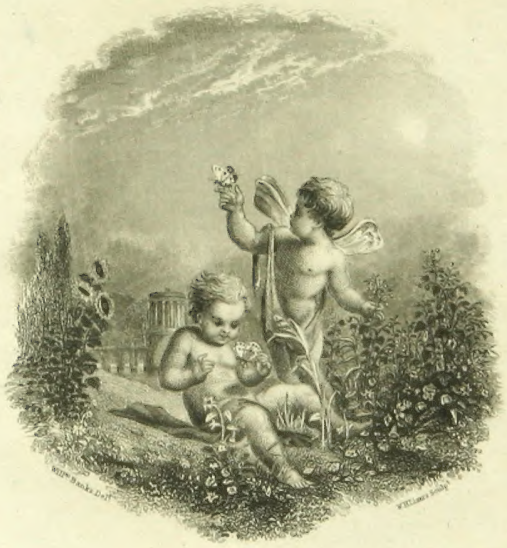

Whatus the vorte to them

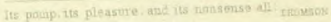

1.ONDON:

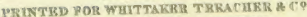

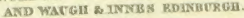

1834 



\section{BOOK OF BUTTERFLIES,}

\section{SPHINGES, AND MOTHS;}

KLLUSTRATED BV

ONE HUNDRED AND FORTY-FOUR ENGRAVINGS,

COLOURED AFTER NATURE.

\section{BY}

\section{CAPTAIN THOMAS BROWN,}

FELLOW OF THE LINNAAN SOCIFTY, MEMBER OF THE WERNERTAN, KIRWANIAN, AND PHIENOLOGICAL SOCIETIES, AND

PRESIDENT OF THF ROYAL PHYSICAL SOCIETY.

\section{Seroñ EEDition.}

IN THREE VOLUMES.

$$
\text { VOL. II. }
$$

\section{LONDON :}

WHITTAKER \& CO. ; AND WAUGH \& INNES, EDINBURGH.

1834. 


$$
\begin{gathered}
Q L \\
542 \\
B 88 \\
1834 \\
V .2 \\
176292
\end{gathered}
$$




\section{CONTENTS.}

3,ife

linsus SPIIINY, or $I I L V K M O T I I S, \quad$. . !

The Ocellated Sphinx, . . . 13

'The Destructive Siphinx, . . . . 17

The Spurge Sphinx, - . . . . 2. .

The Humming-Bird Sphinx, . . 24

Tho Windoryed Sphinx, . . . 27

The Pine Sphinx, . . . . 28

'The Forester Spbinx, . . . 29

The Bloody-Tailed Sphinx, . . .

The Elepbant Sphinx, . . . 31

The Death's Iead Sphinx, . . . 33

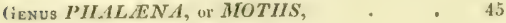

Cirap. I. Direct Injuries from Moths, . . 46

I1. Direct Bencfits from Moths, . 62

III. On the Food of Moths, . $\quad 75$

1V. On tho Inbitations and Architecture of Mothe, . . . 78

v. Of Sociablo Caterpillars, or those rhich live in Socicties, $\quad . \quad$. 94 
GENUS P'IIALAENA, or MOTI, - . 108 The Pink Under-Wing Moth, . . 112 The Cream-Spotted Tigex Moth, . . . 113 The Wandering Moth, . . . 115

The Footman Moth, . . . 116

The Panthona Moth, . . . . 118

The Margate Beauty Moth, . . 119

The Matronula Moth, . . . 120

The Lettered Moth, . . . 121

The Currant Moth, . . . 122

The Crimson Under-Wing Moth, . . 124

The Argent and Sable Moth, . . 125

The Friendly Moth, . . . . 127

The Hebe Moth, . . . . . 128

The Broat Bordered Yellow Undew-Wing Xoth, , 129

The Rliorlope Moth, . . . 131

The Bright Moth, . . . 132

The Snont Moth, . . . 133

The Sinall Tiger Motlt, . . . 134

The Mlack and Cream-Spotted Moth, . . 136

The Maid of Honour Mloth, . . . 137

The liuby Tiger Moth, . . . . 138

The Small Magpio Moth, . . 140

Tho Great Tiger Moth, . . . . 141

The Silkworm Moth, . . . 143 


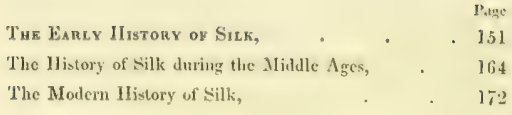

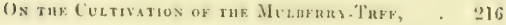





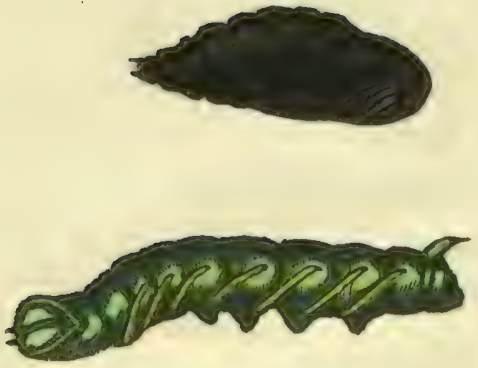

(i1.

PUPA AND LAHVA OF TIE OCFLLATED SUIINX, Sphin. Ocellata.-Buiтain. 


\title{
BOOK OF BUTTERFLIES.
}

\author{
GENUS SPIINX, OR IIAWK MOTHS.
}

Tre insects of the genus Sphinx are sometimes, in Britain, called Hawk Moths. They have, in general, a large thorax, and thick body, most usual. ly tapering towards the tail, or posterior extremity.

The name of this genus is derived from the position assumed by several of the caterpillars of the larger species bearing a strong resemblance to that of the Egyptian Sphinx, the fore parts being elevated, and the rest of the body adhering flatly to the surface on which it rests.

The flight of the larger species is generally in the twilight of evening, or early in the dawn of morning. Some of the smaller ones are to be met with during day, although they are much more rarely seen than butterflies. 
This tribe feeds on the nectar of flowers, which they extract with their long flexible tongues.

The catcrpillars have sixteen feet, and are mostly very active in their habits; those of the Linmean division, called Zygeener, are thick, fat, and covered with short hairs; those of the Sesice are generally smooth, unarmed, and thinner towards the head; the others have usually a sharp, erect, stiff horn behind. The pupe are quiescent; those of the Zuyyana: folliculate, and a little tapering forwards; the rest naked and smooth; those of the Sesice pointed at each cnd-of the others, very obtuse behind; and many of the species spin their cocoons under ground, making them up with small particles of earth and grains of corn, interwoven with silky filaments.

The caterpillars of some of the sphinges, more particularly that of the Privet Hawk Moth, when in a state of repose, hold firmly with their fore legs the branch on which they are standing, and erect the anterior part of their body so as to form nearly a right angle with the posterior, and remain motionless in this singular attitude for hours. By this means they clude observation, and may be taken for the twig of a tree. It is mentioncd by Reaumur, that a gardener in the service of Jussicu, the celebrated botanist, used to be much annoyed at the appearance of these caterpillars; he conceived that the self-sufficient air which they manifested indi- 
cated much pride in the creature, as he had never seen other lavve hold their heads so high.

Linnacus divides this genus into the following sections:-

A. With the antenne scaly; the feelers hairy; and the tongue spiral.

Plate 61, lower figure, represents the larva of the Ocellated Sphinx, a species of this section; and the upper figure, the pupa of the same insect.

B. Sesid.-The antenna are cylindrical; the tongue is exserted and truncate; and the wings entire.

C. ZYGANE.-The antenno are thicker in the middle; and the tongue exserted and setaceous.

The species of this genus are far less numerous than those of the Papilio and the Phalcena; on that account we have been more limited in the representations. There is, besides, little striking in their history or peculiarities, except in a few of the individuals, namely, - those of the OcellatedSphinx, the Destructive Sphinx, and the Death's Head.

The larva of many of the sphinges are exceedingly destructive to trees and shrubs, penetrating into them, and often causing their total decay. $\mathrm{Mr}$ Joseph Hayward remarks on this subject, "Having been balked in my endeavours to raise and train some young currant bushes in a particular manner, from their failing to grow so luxuriantly as I had reason to expect, from the pains I had taken to 
prepare the soil, \&c., I was led to a narrow examination of their extcrior in search of the cause; and perceiving some wounds in the branches, that had much the appearance of being made by the entrance of small shot, I cut off a branch, when I found that the medulla, or pith, was destroyed, and its place converted into a commodious apartment and passage for some insects. I traced it for several inches, and found it occupied by a grub, or maggot; and knowing this must be the larve of some fly or moth, I determined on securing a few of them at the proper season, to see the result of their transformations. Having obtaincd some in a chrysalis state, I placed them under a glass, when, after some weeks, one of them produced a beautiful specimen of the Aigeria tipuliformis."

A few only of the sphinges are remarkable for the gayety and splendour of their colours, which render the butterfly tribe so pleasing and interesting to general observers. There is, however, to counterbalance this, a peculiar grace and elegance of form throughout the whole of the sphinges, which at once distinguish them from the moths. The sphinges of Britain are not numerous, being, as is the case in other regions of the globe, a very limited genus when compared with the butterflies and moths. 



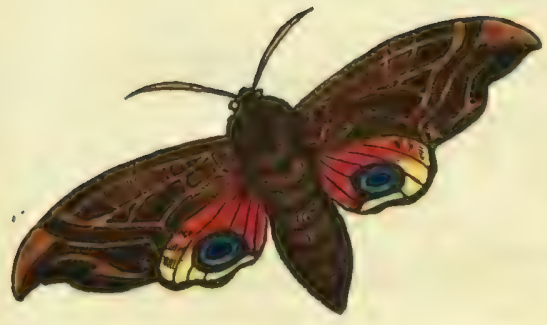

62.

THE OCELLATED BPHINX.

Sphinx Ocellata._Britain. 
TIE OCELLATED SPIINX.

Sphinx Occllala.-Bartais.

PLATE LX11.

Sphinx Occllata, Linn. Syst. Nat. ii. p. 796._Donovan"s Brit. Ins. viii. pl. 269.-Marris' Aurelian, pl. 5, fig. o. H.Albin, pl. 8, fig. 2.

As an example of its genus, the Ocellated Sphinx is probably one of the most elegant which is produced in Great Britain. The upper wings and body are of a beautiful reddish brown; the lower wings, at their insertion, are of a deep carmine, gradually softening off till it becomes of a pale rose colour, terminating in a citron yellow at their bases. Towards the margin on each wing is a large circular spot, like an eye, black in the centre, surrounded with a ring of deep ultramarine blue, quite iridescent, changing to the most beautiful pale cobalt blue, and the whole surrounded by a black fillet. The caterpillar is of a willow-green colour, and generally feeds on willows. It arrives at its full size towards the beginning of August, when it buries itself in the earth, and changes into a clurysalis of a bistre colour. A bout the first week in June following it ennerges, in the form of the perfect sphinx.

The alteration of form during the different periods 
of life which the insects of the papilionaceous tribe undergo, affords a subject of the most pleasing contemplation to the mind of the naturalist. Though a deeply philosophical survey demonstrates that there is no real or absolute change produced in the identity of the creature itself, but that it is in reality only the gradual and progressive evolution of parts before concealed, which lay in embryo, masked under the form of an insect of a widely different appearance, yet it is justly viewed with the lighest admiration, and even generally acknowledged to be in the most lively manner typical of the last eventful change of humanity.

If any regard is to be paid to a similarity of names, it would seem that the ancients were sufficiently struck with the transformations of the butterfly, and its revival from a sceming temporary death, and considered it as an emblem of the soul, the Greck word $\psi v \times n$ (Psyche) signifying the soul, and also a butterfly.

Modern naturalists, impressed with the same idea, have drawn their allusions to the resurrection of the body, from the dormant condition of papilionaceous insects, during their state of chrysalis, and their resuscitation from it ; but they have, unfortunately, chosen a species the least proper for the purpose, namely the silkworm, - a species which neither undergoes its change under the surface of the earth, nor, when emerged from its tomb, is it an insect of 
remarkable beauty; but the larva, or caterpillar, of the Sphinx, when satiated with the food allotted to it by nature, retires to a very considerable depth beneath the surface of the ground, where it divests itself of all appearance of its former state, and continues buried for several months; then works its way to the surface, bursts from the confinement of its tomb, and commences a being of powers so comparatively exalted, and of beauty so superior, as to be one of the most elegant of the whole insect tribe, disporting, in its splendid attire, through the atmosphere.

Even the animated illustration of the resurrection, taken from the vegetable world, so justly admired, must yield, in the force of its similitude, to that. drawn from insect life, since Nature exhibits few phenomena that ean equal so wonderful a transformation.

This extraordinary metamorphosis is thus described by an anonymous poet; which we suppose to be Dr Shaw.

Tho helpless crawling enterpillar trace, From the first period of his reptile race: Clothed in dishonour on the leafy spray, Unseen, he wears his silent hours away ; Till satiate grown of all that life supplies, Self-taught, the voluntary martyr dies. Deep under earth his darkling course lie bends, And to tho tomb a willing gucst deseends; 
There, long secluded in his lonely cell, Forgets the sun, and biels the world farewell. 1) 'er the wide waste the wintry tempests reign, And driving snows usurp the frozen plain: In vain the tempest beats, the whirlwind blows, Xo storus can violate his grave's repose; 33ut, when revolving montbs have won their wny, When smile the woods, and when the zephyrs pliny, When laughs the vivid world in summer's bloom, Ie bursts, and flics triumphant from the tomb! And, while his new-born beanties he displays, With conecions joy his alter'll form surveys. Mark, white he moves amid the sunny besm, ) $\mathrm{er}$ his soft wings the varying lustre gleam. Lanch'd into air, on purple plumes he soars, Giay Nature's face with wanton glanee explores; l'roul of his various beaties, wings his way, And spoils the fairest flowers, himself more fiir than they,And deens weak Man the future promise vain, When worms can dic, and glorious rise aşain. 



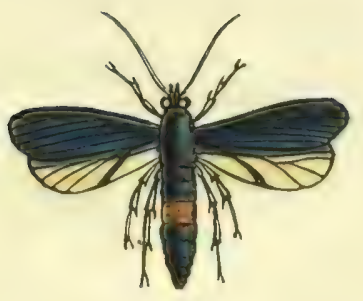

63.

THR DFSTUCTIVF SPIINX.

Sphinx Exitiosa.-А иентс. 
THE DESTRUCTIVE SPIINX.

Sphinx Exitiosa.-U UIтED STAтEg.

PLATE LXIIT.

Egeria Exitiosa, Say.—Journal of the Academy of Nalural Sciences, vol. iii. p. 216, New.-Say, American Entomo$\log y$, vol. ii. pl. 19 ; upper and middle figures.

MaLe.-The body is steel-blue ; antennze ciliated on the inner side, black, with a tinge of blue; palpi beneath yellow; head with a band at its base; both above and beneath pale yellow; eyes black-brown; the thorax with two pale yellow longitudinal lines, and a transverse one behind, interrupted above, and a spot of the same colour beneath the origin of the wings; the wings are hyaline; nervures and margin steel-blue, which is more dilated on the costal margin, and on the anastomosing band of the superior wings; the feet are steel-blue; the coxa two bands on the tibire, including the spines, incisures of the posterior tarsi, and anterior tarsi behind, pale yellow; the abdomen, with two very narrow pale yellow bands, one of which is near the base, and the other on the middle; the tail is fringed, the fringe margined with white on each side.

Fesale.-The body is rery dark steel-blue, with 
a tinge of purple; the antennxe destitute of cilise; the palpi are black beneath; the thorax is immaculate; the superior wings are steel-blue, without any hyaline spot: the inferior wings are hyaline, with an opaque margin, and longitudinal line of the latter colour; the tergum, with the fifth segment, bright reddish fulvous.

The Pupa has two semifascia of spines upon each of the segments, excepting the three terminal ones, which have a single row only.

The Follicle is brown, oblong-oval, composed of small pieces of bark and earth, closely connected together by the web of the animal.

This insect has been for years the cause of great solicitude and regret to all the lovers of fine fruit in America. Small as this creature is, measuring only half an inch in length, it is the silent, insidious destroyer of the peach-tree.

The sexes are so remarkably different from each other, that it was with much diffidence Mr Say yielded his assent to their specific unity, and that was from a knowledge of the circumstance that the sexes of many of the species are very unlike each other. In this instance, the difference is so great as to render it difficult to construct a good common specific character.

It was to Mr James W Worth, a zealous and careful observer, that MIr Say was indebted for the principal part of the accurate information which he 
possessed of this sphinx. The following observations are extracted from a valuable essay by that gentleman, published in the third volume of the American Transactions.

The egg, deposited on the side of a glass tumbler, was oblong-oval, dull yellow, and so small as to be only just discernible by the naked eye. Excepting in a state of confinement, he never saw the female at rest but in one instance, when she was perched on a leaf, which may possibly be the usual place of deposit, though he is inclined to belicve that it is made on some part of the trunk of the tree. The larva is white, with a reddish brown head. It is somewhat difficult to ascertain the carly movements of the larva, in consequence of its small size ; but its destructive career certainly commences about the end of September, or beginning of October, by its entering the tree, probably through the tender bark under the surface of the soil; after having passed through the bark, it proceeds downwards into the root, and finally turns its course towards the surface, where it arives about the commencement of the succeding July.

Having attained to its full growth, the larva enters the pupa state between the first and iniddle of July; enveloped in its follicle, it may then be readily discovered close to the trunk, surrounded by the gum which oozes from the wound. The following is a - figure of 
THE FOLLICLE.

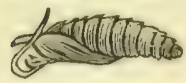

EXUVIA OR TIIE PUTA.

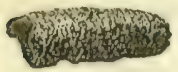

The pupa state continues from the tenth of July to the latter end of that month, or beginning of August.

Mr Worth examined his fruit-trees on the tenth of July, when he obtained twenty follicles, and about thirty larve; of the follicles, four were empty, the insect having assumed the winged state. The larva lad all arrived near the surface of the ground, for the purpose of undergoing their great change.

Against the depredations of this insect, many supposed remedics have been prescribed,-such as the application of hot water, tanner's bark, and flower: of sulphur, to the root of the tree, and soft soap and lime-wash to the trunk; but it is obvious, that no application of this kind can injure the insect without coming in contact with it, whilst it remains in the egg, or infantile state, on the outside of the tree; for', after having penctrated to the interior, no superficial application can affect it. The various substances placed around the root of the tree, such as ashes 
and sand, the uncovering of its base during winter, covering again for the summer, are also pronounced by Mr Worth, from his experience, to be inefficient, and even injurious to the health of the tree. 


\section{THE SPURGE SPIINX.}

Splinx Euphorbice.-Eunope.

PLATE LXIV.

Sphinx Euphorbix, Linn. S'yst. Nat. ii. p. 802.-Shatc's Nat. Miscelleny, pl. 922. -Drury's Ins. Exot. i. pl. 29, fig. 3.-Reaumur's Ins. i. pl. 13. fig. 1, 4, 5, 6.-Turton's Linné, iii. p. 173.-Donovan's Brit. Ins. iii. pl. 91, 92.

Tre superior, or upper wings, are of a rich fawn colour, with the anterior margins of a brilliant leekgreen, and a large cloud of the same colour towards their insertion into the body, and two semilunar spots nearer the tips of the wings; there is a double articulate black band, with a leek-green centre, towards their posterior margins, bounded by a border of brownish purple; the under wings have a black bar at their insertion, bounded by a band of rich crimson, below which is a band of black, and a border of pale chestnut ; the anterior and posterior margins of both upper and under wings are white, fimbriated at their edges. The lody is thick, of a rich leekgreen; the whole, from the head downwards, edged with pale chestnut; and two spots of the same on the back, alove which are two white spots. The eyes are white, and the antennec chestnut, and club-shaped.

The Spurge Sphinx, considered as a native of Britain, is, without exception, the rarest species of the genus. 


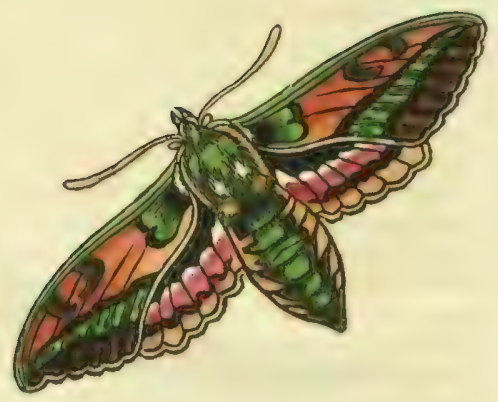

64.

THF STULGE, SPHIX.

Sphinx Euphorbia.-Gersıку. 

Drury has figured this sphinx, without its changes, among his rare insects, but as a native of a foreign country; and before the time of Harris, it was often an object of discussion among collectors, whether it had ever been taken in England. Harris says, "It has long been in dispute, whether the Spotted Elephant was a native of this island; but it is now past a doubt, as I had the good fortune to find a caterpillar of this moth in marshy ground at Barnscray, near Crayford, in Kent, about the middle of A ugust. It was better than three inches long, of a dark brown colour; the horn at the tail part, which was about lalf an inch long, appeared black and glossy. The head was nearly the size of a small pea, and of a lightish yellow brown, or tan colour. I tried various herbs to bring it to feed, but my attempts were fruitless, and it died for want." He mentions that the chrysalis, in the plate which he figured, wats sent to him from Belisle, in France; and the moth was transforned from it in the beginning of June.

The Spurge Splinx is common in many parts of Germany, France, and the Netherlands. It is figured of the natural size in the annexed plate. The caterpillar feeds on the smaller, or European, species of the genus Fuphorbia. It changes to a chrysalis in the month of August, from which, in the following June, emerges the perfect insect, in its imago condition; in which state it has few cyuals in point of colour. 


\section{TIE IIUMMING-BIRD SPIINX.}

Sphinx Stellatarum.-Butain.

PLATE LXV.

Sphinx Stellatarum, Linn. Syst. Nat. ii. p. 803.—Turton's Linné, iii. p. 179.-Donowan's Brit. Ins. v. p. 155.Cramer, Insects, pl. 24, c.-Shaw's Nat. Miscellany, pl. 872 .

THE superior wings of this beautiful little insect are of a deep brown, with two waved sesquialterous bands, and a dimidiate band and black spots on each; the under wings are of a greenish yellow in some individuals, and of a rich orange in others; the thorax is large, round, and capacious; and the abdomen thick, brown, and hairy beneath; on the lower part of which are two white spots on each side, and a white spot on each side of the thorax, beneath the head, which is sharp and pointed; the eyes are large, and the antennæe club-shaped in some, and, in others, they are thickest in the middle ; the annulations of the abdomen terminate with a transverse tail, not unlike that of a bird.

There are two sorts of caterpillars belonging to this species. They are alike in size and form, but are very different in colour. One sort is green, the 


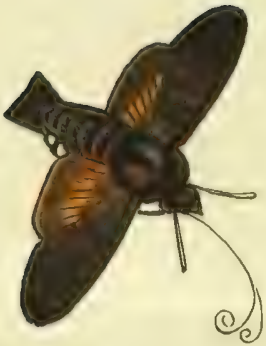

65.

THF HUMMANG BIRD SPUINX,

Sphinx s'bellakrum.—BRItark. 

other purplish red, varying much in different specimens, being sometimes almost brown; both are covered with minute white specks, which are disposed in regular order over every part, except the belly.

Every catcrpillar is furnished with a posterior horn, which is blue from the base for more than half its length, the tip being of a bright orange colour.

The chrysalis, which is of a yellowish brown at first, changes to a more dusky colour before the transformation of the Sphinx.

The caterpillars feed on several kinds of plants, but seem chiefly to prefer those of the galium genus, particularly the white, (palustre,) or the yellow, (verum,) and eleavers, or goosegrass, (aperine.) They go into the ground about the latter end of August, where they change into the chrysalis, and remain immured till nearly the end of A pril or May in the following year.

The Humming-bird Sphinx is rather a searee insect; it sometimes visits gardens in the winged state, and may be secn flying rapidly from flower to flower, extracting their nectar by darting its long tubular proboscis into them. It is from this peculiarity, and its hovering over the flowers at the same time, like the humming-bixds when they feed, that it has acquired its English appcllation.

This Sphinx is found in most parts of Europe, but it appears more frequently in the northern countries. voL. II. 
A variety is found in Botany Bay, and also in North America.

It may be remarked, that the Sphinx Belis of Linnæus and Cramer is described amongst the synonyms given by Fabricius, as a variety of Sphinx Stellatarum; and Sphinx Ciculus of Cramer differs but little from this insect, so that it may be considered the same species. 



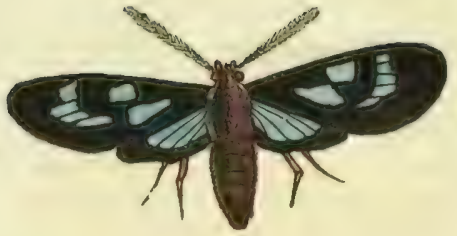

c

66.

TUF WINDOWED SPHNX.

Sphinx Fenestrata, Jarasca. 


\section{THE WINDOWED SPIINX.}

Sphinv Fenestrata.

-PL,ATE LXVI.

Sphinx Fenestrata, Drury, Ins. ii. pl. 28, fig. 5-Turton's Linne, iii. p. 185.

THE wings of this insect are of a deep brownish black, with transparent glass-like spots, three on each of the upper wings, and a larger one on each of the under wings, through which any object can be distinctly seen, from their extreme clearness. The body is thick, of a rich brown colour, the abdomen consisting of alternate black and yellow bands. The head is small, and the eyes and legs are scarlet; the thorax with three black spots on it.

This curious insect is a native of Jamaica. 
THE PINE SPIIINX.

Sphinx Pinasiri.

PLATE LXYIT.

Sphinx Pinastri, Linn. Syst. Nat. ii. p. 802.-Turton's Linné iii. p. 172_-Donovan's Brit. Ins, ix. p̧l. 296.

Tre superior wings of the Sphinx Pinastri are of a pale greenish purple, with three black spots towards their centre; the under wings are burnt umberbrown; all of them have a border of black and white spots; the head, thorax, and abdomen, are the same colour as the upner wings, banded with brownish hlack.

The catcrpillar has an orange yellow head; the body is covered with alternate longitudinal stripes of decp green and yellow; along the centre of the back it is white, in the middle of which extends, from the head to the tail, a catenated line of rich reddish brown; and the tail is furnished with a spike.

The pupa is of a deep reddish brown. We have placed it as a British insect, from a traditionary report that it has been found in Scotland, near to Edinburgh, and it is said also to have been found in Sussex. It is a very plentiful species in Germany, among the extensive pine forests which intersect that country. 


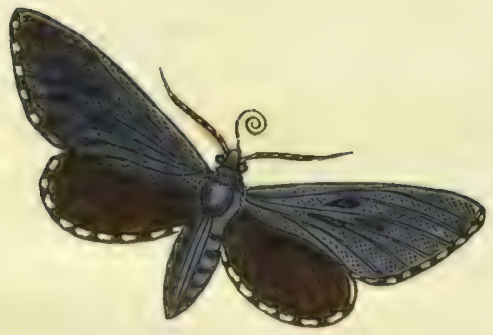

$6 \%$

THF, PINE: SIHINX,

Sphine P'inastri,-Jйтаs. 




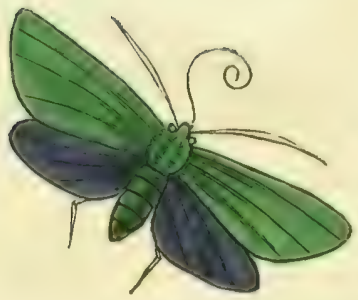

is.

THF FUHFSTHI SFIINX.

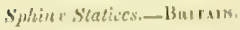




\section{TIIE FORESTER SPHINX.}

\section{Sphine Statices.}

PLATE LXVII.

Sphinx Statices, Linn. Syst. Nat. ii. p. 808.—Donovan's Brit. Ins. vi. pl. 204, fig. 2._Turton's Linné, iii. p. 191.

Tiris very beautiful Sphinx has the superior wings, thorax, and abdomen of a vivid green in some species, while in others it is of a pale yellowish green; the inferior wings are puxple in some, and very pale rose colour in others; they are brown underneath; the antennæ are pectinated, and clubshaped.

The larva is of a deep black, with a line of white down the back, and some lunar-shaped spots of the same colour in different parts. It feeds on docks. The moth is transformed in May, and frequents meadows. The breadth of the insect is an inch and an eighth. Our figure is nearly double the size of nature. The chrysalis is dusky.

This sphinx is not common; it frequents Kent, Surrey, Hertfordshire, Lssex, Middlesex, Yorkshire, Cambridgeshire, and Northumberland. 


\section{TIE BLOODY.TAILED SPIINX.}

Sphinx Hamorrhoidalis.

PLATE I.XIX.

Sphinx Hetmorthoidalis, Turton's Linné, iii. p. 181.Cramer, v. pl. 52, c. D.

TuE wings are hyaline, with a broad black band all round, and a dimidiate black band on the upper wings; the posterior and anal margins are fimbriated; the head is small; the antenne long and fringed; the cyes are crimson ; body thick, temimated with a large rounded tail, thickly covered with fine crimson hairs; back proninent, with a white circular spot on each shoulder, and a girdle of erimson below the back, the thorax with a white spot on cach side, and the abdomen red at each end.

The Bloody-Tailed Sphinx is an inhalitant of India, and is to be found in various islands of the Indian Ocean. The figure is the size of nature. 


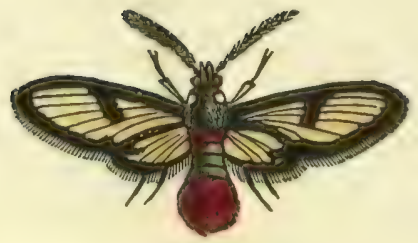

69.

ТнЕ BLOOUY TAILFD SPHINX.

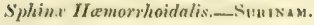






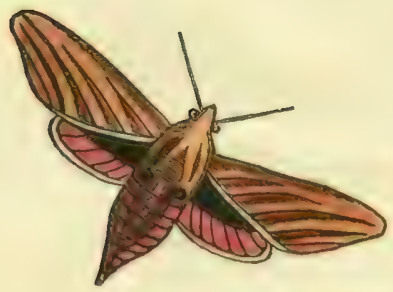

T0.

TIF FLFPHANT SPUINS,

Sphina Elpenor.-Buiтas. 


\section{TIIE FLEPIIANT SPIINX.}

\section{Sphinx Elpenor.}

PLATE LXX.

Suluinx Elpenor, Linn. Syst. Nat. ii. p. 801.-Turton's Linné, iii. p. 175.,Donovan's Brit. Ins, iv. pl. 122,Harris's Aurcl. pl. 7, fig. G. II.

Tue wings of this beautiful Sphinx are two inches one-sixth, to two-thirds of an inch, angular ; the upper ones striped with rich fawn colour and pink; the lower wings are rose coloured, with a large black patch at their insertion ; the thorax is fawn coloured, and the abdomen rose coloured, with two black spots on the upper segment.

The caterpillars of this very elegant Sphinx art generally found in marshy places in June and July. They feed on the convolvulus, vine, and some other plants, but prefer white ladies' bedstraw ; they cast their skin several times; and, when full fed, som. are green, and others of a brown colour. The caterpillars of the female are a fine grcen, elegantly marked with black; those of the male are varied with the same dark markings, but the colour is a dull brown, inclining to black in those parts where the female is green. 
It possesses a faculty peculiar to very few insects-it can protrude its head and three first joints to a tapering point; or entirely conceal the head, and contract the first joints, by drawing them apparently into the body.

The caterpillars form a white wch among the leaves in August, and continue in the pupa state during the winter, when it is yellow. The chrysalis is anteriorly dull gray, and posteriorly brown, with the spiracles obscure. The Sphinx emerges in the following May. They are very subject to attacks from the Ichncumon Fly, to which they frequently fall a sacrifice.

This Sphinx is not uncommon near London, Hertfordshire, Surrey, Devonshire, Shropshire, Cambridgeshire, Yorkshire, and Northumberland.

It is the Deilephila Elpenor of Ochsenheimer; and is subject to considerable variety in the depth of its colours. 



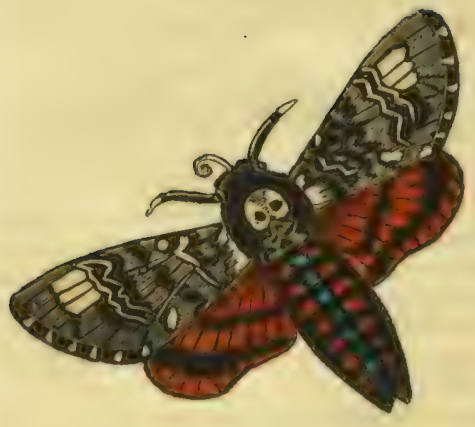

71.

TUE DEATH'S HFAD SPHINX.

Syhin. Alropos.-BRTtain. 


\section{3}

\section{TIE DELTII'S HEAD SPIINX.}

\section{Sphinx Atropos.}

PLAT LXXI.

Sphinx Atropoa, Linn. Syst. Nat. ii. p. 799._Donovan's Brit. Ins. ix. pl. 289; P'upa and Larva, pl. 290_Turton's Linné, iii. p. 172.

Time Deatli's Head Splinx is the largest and most remarkable of its genus, if not the most beautiful of all the European insects of its kind. The upper wings are of a fine dark gray colour, with a few variegations of yellow-orange, and sometines, though rarely, white clouds; the under wings are of a bright orange colour, marked by a pair of transverse black bars, while, along the top of the back, from the thorax to the tail, runs a broad, blue-gray stripe; on the top of the thorax is a very large pateh of a most singular appearance, exactly resembling the usual figure of a skull or death's head, and is of a pale gray, varied with dull ochre colour and black.

When in the least disturbed or irritated, this insect cmits a stridulous sound, something like the squeaking of a bat or a mouse; and from this circumstance, as wen as from the mark above mentioned on the thorax, is held in much dread by the vulgar in several parts of Europe, its appearance being regarded as an ill omen, or harbinger of approaching fate. 
The celebrated Reaumur informs us, that the members of a female convent in France were thrown into great consternation at the appearance of one of these insects, which happened to fly in during the crening at one of the windows of the dormitory.

"The caterpillar from which this curious Sphinx procceds is in the highest degree beautiful, and fax surpasses in size every other European insect of the kind, measuring sometimes near five inches in lengtl, and being of a very considerable thickness : its colour is bright yellow, and the sides marked by a row of seven most elegant broad stripes, or bands, of a vivid violet and sky-blue colour; the tops of these bands meet on the back in so many angles, and are varied on that part with jet black specks ; on the last joint of the body is a horn, or process, not in an erect position, but hanging or curving over the joint in the manner of a tail, having a rough or muricated surface, and of a yellow colour. This caterpillar is principally found on the potato and jessamine, those plants being its favourite food. It usually changes into a chrysalis in the month of September, retiring for that purpose pretty deep under the surface of the earth, the complete insect emerging in the following June or July; but some individuals are observed to change into a chrysalis in July or August; and these produce the complete insect in November; so that there appear to be two broods or aunual races."

The Death's Head Sphinx is generally considered 
as a very rare insect; and, as the caterpillar foeds chicfly by night, concealing itself during the day under leaves, \&c., it is not often detected; yet, from some singular circumstances favourable to its lireed, there are some seasons in which it is even plentiful. Dr Shaw tells us, that in the autumn of 1804, the caterpillar was so common in some countries as to be very prejudicial to the potato plants, particularly in some parts of Cornwall and Surrey.

This animal is a great enemy to bees; and on this interesting point I shall quote what Mr Huber states, in a chapter entitled, "On a New Enemy of Becs." "Among the labours of insects," says he, "those which concen the defence of their habitations are not the least deserving the attention of man, who is so often called on to fortify himself against the enterprises of his enemies. It is here that Nature unfolds the most unexpected resources, where she admits of the greatest latitude; for the chances of war are the olject of one of those general laws concurring to the preservation of universal order. Without the alternatives of success and reverse, how could an equilibrium be maintained? One species, endowed with superior strength, would annihilate another. Nevertheless, the most timid have sulssisted since the origin of things; their tactics, their industry, and their fecundity, or other circumstances peculiar to their kind, have enabled them to escape that extinction which seems to menace them. 
"Among bees, as with the greater part of their class, the ordinary means of resistance are those poisoned weapons with which they wound their enemies. The fate of war would be more in their favour, were not several of their antagonists armed still better than themselves,-if others had not the art of shunning their vigilance by sheltering themselves under a covering, - and were there not also some which can profit, by the weakness of an illpeopled hive, to gain a surreptitious introduction into it.

"Wasps, hornets, the larvo of moths, and mice, have been known from all antiquity by their ravages among hives; and having nothing to add to what is generally said respecting them, I shall confine myself to pointing out a new enemy of bees.

"Towards the close of summer, after having stored up part of their collections, we sometimes hear a surprising noise in their habitations. A multitude of workers depart through the night, and lose themselves in the air ; the tumult frequently continues during several hours, and on examining into the consequences of so great an agitation in the morning, we find numbers dead before the hive. For the most part, the honey is observed to be exhausted, and occasionally the hive is quite deserted.

"In the year 1804, many of my neighbouring cultivators came to consult me on an occurrence of this nature. But I could give them no explana- 
tions; notwithstanding my long practice in studying bees, I never had seen any thing similar.

"On visiting the scene, I found the phenomenon still subsisting, and that it had been very accurately described; but it was assigned to the introduction of bats into the hives, which I had difficulty in crediting. These creatures are satisfied with seizing nocturnal insects in their flight, which are never wanting in summer. They do not feed on honey; why, therefore, should they attack bees in their habitations, for the purpose of pillaging their stores?

"However, it might be some other animal: therefore, having put my people in ambush, they soon brought me intelligence, not of bats, indeed, but of the Sphinx Atropos, or Death's Head, a large moth flying in numbers about the hives; and one was caught at the moment of attempting to penetrate a live among the least populous, where it evidently designed living at the expense of the bees.

"From all quarters I had information of similar ravages committed by bats, as supposed. Cultivators who expected a plentiful harvest, found their hives as light as in the first days of spring; though recently well provisioned, they were now reduced to the weight of wax.

"At length, the gigantic moth which had oceasioned the desertion of the bees, was surprised in several hives.

"Such reiterated proofs were requisite to per- 
suade me that a butterfly, an insect wanting a sting, unprovided with any shield or other means of defence, could contend victoriously against thousands of bees; but this year they were so common, that it was easy to be convinced of the fact.

"As the enterprises of the Sphinx constantly became more fatal to the bees, we resolved to prevent its access, by contracting the entrance of the hive by a kind of grating large enough to admit none but its proper tenants. This plan had complete success, quict was restored, and the devastation ceased.

"The same precautions bad not been universally taken; but we observed that the bees, left to themselves, had provided for their own security. Without any foreign aid, they had barricaded theinselves, by means of a thick wall of propolis and wax, rising behind the entrance of the hive, sometimes in the entrance itself, and completely obstructing it, but penetrated by passages for one or two workers at a time.

" The operations of man and of the insect had completely coincided.

"The works which the bees had established were of very various formation. Here was a single wall, whose opening arcades were disposed in its ligher part; there several bulwarks behind each other recalled the bastions of our citadels. Gateways, masked by walls in front, opened on the face of 
those of the second row, while they did not correspond with the apertures of the first. Sometimes a series of intersecting arcades permitted free egress to the bees, but refused admittance to their enemies. These fortifications were massy; their substance firm and compact.

"As such casemated gates are not constructed by bees without urgent necessity, we cannot aseribe their proccedings to any of those demonstrations of prudence prepared to obviate inconveniences, which the insect neither can know nor anticipate. It is only when danger is present, when it is pressing and immediate, that, compelled to seek protection, it employs this last resource. Thus it is curious to observe an insect, so well armed and supported by the advantage of numbers, securing itself by an admirable combination against the inefficiency of its weapons and its courage. The art of warfare among bees, therefore, is not restricted to attacking their enemies; they know also to construct ramparts, as shelter from their enterprises; from the part of simple soldiers, they pass to that of engineers.

"But it is not against the Sphinx alone that they must be guarded. Weak lives are sometimes attacked by stranger becs, attracted by the odour of the honey, and the hopes of casy pillage. Those beset, veing unable to defend themselves from this invasion, are known to have recourse to a measure resembling that employed against the hostile moth. 
Then, also, they raise walls, leaving only narrow openings for the passage of a single bec at a time, and which, therefore, can be easily protected.

"But a period arrives when these galleries are no longer suitable to the bees. $\Lambda$ the time that their harvest is abundant, their hive excessively populous, and the formation of now colonies approaches, they demolish the gateways which had been erected in the hour of danger, and which now restrain their impetuosity. Such safeguards have become inconvenient, and they are removed, until new alarms demand their reconstruction.

"The entrances formed in $180 \mathrm{k}$, were destroyed in spring 1805. The Sphinx did not appear that year, nor was it seen in the year following; but it retumed in great numbers in autumn 180\%. By speedily barricading themselves, the bees prevented their threatened ravages; but before the departure swarms, in Nay 1808, they demolished the fortifications, whose narrow passages prohibited free egress to the multitude.

"When the entrance to the hive is itself restricted, on care being taken to contract it soon enough to prevent the devastation of their enemies, bees dispense with walling themselves in. We cannot explain their conduct otherwise, than by admitting the evolution of their instinct according as excited by circumstances.

"But how can the Sphinx alarm colonies so 
warlike? How can a moth, the dread of superstitious people, also exercise a secret influence orer insects, and have the fuculty of paralyzing their courage? Does it cmit any emanation pernicious to bees?

"Other species of sphinges subsist on the nectur of flowers alone; they have a long, slender, flexible, spiral trunk, and seek their food at sunset. But the Atropos is later on the wing; nor does it hover about the hives until night is far advanced. It is provided with a thick, short proboseis; is endowed with great strength; and when seized, some unknown organ emits an acute stridulous sound. May not this, which inspires the vulgar with sinister ideas, be also the dread of bees? May not its rescmblance to that emitted by the queen in her captivity, which has the faculty of suspending the vigilance of the workers, explain the disorder observed in their hive on the approach of the Sphinx? But this is only a conjecture, founded on the analogy of sounds, to which I attach no importanee. Meantime, were any piercing notes observed to proceed from the Sphinx during its assaults, and that the bees then yiclded without resistance, my conjecture would acquire some weight.*

- "Reaunur ascribes the sound to the friction of the trunk against its sheatles, but wo have ascertaincd that this oryan has no share in it. Though many naturalists have investigated it, source, nothing satisfictory is known on the subject. It is un-

VOL. II. 
"The introduction of a butterfly so large and $\mathrm{x}$ cognizable as the Sphinx A tropos into a well-peopled hive, and the extraordinary consequenes thenee resulting, are phenomena of the more difficult explanation, from nothing in the organization of the insect indicating that it is screened from the sting of bees.

"We have been anxious to witness this singular contest in glass hives, but no opportunity has hitherto offered. However, to solve some of my doubts, I have made a few experiments on the mode in which the Sphinx is received loy humble bees.

"Ilaving procured some of the largest size, I introduced them at nightfall into a glass box, where a colony of small brown humble bees (Muscorum) had been established. The first carried thither did not appear to be affected by the smell of the honey; it remained quiet in a comer. Beginning to approach the nest and its inhabitants, it soon became the olject, not of the dread, but of the wrath of the workers. Repeatedly assailing it with fury, they gave it frequent stings; it sought to escape ; it ran quickly; and, at last, raising the glass cover of the apparatus by a violent exertion, succecded. It scemed to suffer very little from its wounds; remained tranquil all the night; and several days after was wonderfully well.

doubted that the Sphinx emits the sound at pleasurc, and particularly when affocted by tho apprelension of danger. 
"Another Sphinx, very vigorous and lively, which often emitted the sound peculiar to its species, was confined along with the same colony. Its activity only sersed to renter it sooner the victim of their ratge. Immediately on approaching the nest, which, nevertheless, it secmed to have no desire to enter, all the workers darted on it at once with their stings, and harassed the creature so incessantly as to comprel it to retreat. The moth defended itself only loy the violent agitation of its wings, but it could not ('vade the attacks of the humble bees under the belly, where it seemed most sensible of their weapons. $\Delta t$ length, after in hour of suffering, it perished under many wounds.

"I was unvilling to carry this cruel experiment firther. Captivity, or some other circumstance. evidently reduced the insect to too great an inferiority to the lumble bees. Yet, after the experiment, it beeame still more difficult for me to understand how it could introduce itself into the hives of eommon hees, whose stings are so much more dangerous, as well as their numbers incomparably greater. Inad the light of a toreh been an obstacle to the Sylnimx exercising its means of attack? Possibly the suceess of its enterprises on hives results from the faculty of seeing during the night, like other moths of the same genus.

"Offering honey to these insects was equally 
fiuitless. They remained during a week beside a comb without touching it ; we unfulded the probocis, and dipped it among honey in vain. This experiment, though succeeding perfectly with day butterflies, proved abortive with the Sphinx Atropos.

"Had I not obtained proofs of its avidity while in the natural state, I might lave cntertained doubts of the predilection for honey. Besides, the facts above related are supported by my having recently dissected a large Sphinx taken in the open air, and found the abdomen quite full of pure honey, of the same taste and consistence as that of the bees. The quantity would have filled a tablespoon; and what appeared very singular, was its not being contained in any particular intestine, but occupying the eavity usually reserved for air in the hody of these insects. All the vertical delicate membranes dividing the abdomen into so many compartments had disapjeared, I cannot affirm positively whether they had been ruptured ly the quantity of honey gorging the Sphinx, or by ourselves; but one thing is undoubted, that in others of the Sphinx Atropos, opened by us, we have always scen the receptacles entire, though empty." 


\section{GENUS PHALENA, OR MOTHS.}

ALmost the whole tribe of Moths are nocturnal animals; and, in general, their caterpillars are very destructive creatures.

The general transformations, as described in the first volume, apply to all the lepidopterous insects; but the architecture and particular cconomy of Moths was reserved for the introduction to this genus. 


\section{CHAPTER I.}

DIRECT INJURIES FIROM MOTIS.

Wirir respect to the direct injuries which are caused by motlss to mankind, I may mention, that the hairs of several caterpillars of the gemus Phalana are exceedingly troublesome, producing the same effects on the human skin as the hairs which grow on the pods of the cow-hedge, (I) olichos pruriens et urens of hinnaus,) which occasion a disagreeable, and, to some individuals, a painful itching.* The larve of several of the family of moths calledBombyx, of which number is the Processionary Moth, have this quality. M. Reaumur has given an interesting and curious account of the effects of these, produced on himself, He had been handling some of these larre,

- Messis Kirby and Spenee say, that " cow-hetge has been administered with suceses as an anthelwinthic, ns has likewise spun glass powdered, the spicula of these substanees destroying the worms." The hair of the eaterpillars here alluded to, and, perhaps, also of the larva of Bombyx Caja, (tho Tiger Moth,) might probably be cqually efficacious. 
the hairs of which adhered to his skin, and he suffered considerable uncasiness from them for some days. He was not aware of the eause of his disquictude; and, having also rubbed his eyes while his hands were studded with these spines, they produced such a degree of inflammation and swelling in the eyclids, that he opened them with much difficulty. Disagrecable effects were also produced in ladies who went near the nests of these caterpillars. Tumours were indued on their necks, which could only be accounted for by the short hairs, or fragments of them, being foreed into their skin from standing in the direction of the wind." "The larva of the moth of the Fir (Bombyx pilyocumjut of Fabricius) produces similar effects, causing even intense pain, fever, itching, and great restlessness. This was the celebrated P'ityocermpe of the ancients, considered by the liomans as a deadly poison, as will appear from the Cornelian law, "Dr sicariis," being made to include those who administered Pityocampa. $P^{\prime}$

We are infonned, in a paper in the I'litosophlical Trrmsuctions, by J)r Lister, a celelrated naturalist and plyssician in the reign of Queen Ame, that a boy vomited up several living eaterpillars, with sixteen legs. It is easy to suppose that he must have swallowed insects' eggs, while eating some

- Rfaumur, Mem. des Insectes, ii. p. 191-5.

+ Punv, Irish. Nat, i. 38, c. 9. 
veretable substance on which they had been deposited, and that they had undergone transformations into the larvia state in his stomach. It is very (n)mmon for the larvie of beetles, \&c. to be generated in the stomach, and roided alive, which can only be accounted for by swallowing them in the egg state.

Azara, a celebrated Spanish traveller, informs us, that, in South $\Lambda$ meriea, there is a large brown moth, which produces its egrgs in a gelatinous substance npon the skins of persons who sleep naked, where they transform into the larva state; then insinuate themselves under the skin, producing swelling, infitmmation, and excessive pain. These, when moticed by the native Indians, are squeezed out. 'Tliey generally amount to five or six individuals.*

$A$ very destructive moth is the Antler moth, Bomlyyx (iraminis of Linnacus ; and, although less frequently met with in this country than on the Coutinent, is nevertheless sometimes a most troublesime pest to our furmer's. In the year 1759 and 1802 , the caterpillar of this Phalaena proved a dreadfill seourge to many of the higher sheep farms of 'I weeddale in Seotlani. In certain spots, the grass, lirr a mile square, was totally devoured by it. $\uparrow$ In the year 1740, 1\% 11 , and 1742 , in Sweden, these larrie multiplied so prodigiously, and committed such ravages, that the fields were quite eaten up by

- Azana's Trueels, p. 217. +Farmers' Mag. iii. 487. 
them, and had the appearance of having been consumed by fire. ${ }^{\text {*t }}$

Still farther to the north, according to the account of Pallas, a moth of another species is even more troublesome and destructive than that above mentioned, extending its ravages to almost all green things. This celebrated traveller tells us, that in Kasau, a government of European Russia, lying between the $46^{\circ} 20^{\prime}$ and $49^{\circ} 40^{\prime}$ east longitude, and the $54^{\circ}$ and $57^{\circ}$ of north latitude, the larva of the Plateren firmentalis not unfrequently eats the greater part of the spring corn to the root.t

There is a white moth, the caterpillar of which is a great nuisance to the sugar planters ; it is called the Borer, and makes dreadful havoc amongst the sugar canes of many of the colonies. The Society of $\Lambda \mathrm{rts}$ offered a reward of fifty guineas to any one who could invent a method for their destruction; but no effectual plan has yet been devised for expelling them.

While on this subject, I may mention an insect, although of a different order, which, in the West Indies, commits still more dreadful havoc. A frightful picture of their depredations is recorded in the Philosophical Transactions. $\ddagger$ This is a species of ant, (the Formica saccharicora of Limnæus,)

- De Geer, ii. 341.

+ Palcas's Travels in South Russia, i. 30.

$\mp$ Vol. xxx. p. 346 . 
which does not prey upon the sugar eanes, but makes its nest under the roots, and injures them so much, that they soon become unhealthy and unproductive. A hout cight $y$-five years ago, these destruetive creatures were produced in the island of Granada in such inconceivable numbers, as totally to ruin the cultivation of this valuable plant. They descended from the higher grounds like mighty torrents, and swept every thing before them. Every road, and lane, and plantation, were inundatcel by them. Domestic quadrupeds perished in consequence of this awful pest. Even wild animals, rats, mice, and reptiles, became a prey to them ; and birds, which alighted in search of food, fell victims to these marauders. Such was the determination of their advances, that streams of water offered but a momentary check to their progress. These which formed the van fiarlesily sacrificed themselves for the common good-each followed his fellow, till an cmbankment or lam of the drowned insects was formed. when the main body passed over in safety. Fires were lighted of dry vegetable substances, and the grass was ignited, but this formed no greater an obstacke than the water; for, even then, it was only those in front who suffered, and soon extinguished the flames, hy the countless numbers of their carcases, allowing their followers to pursue their pestilential march unhurt. The whole of the standing sugar canes were at length bumt down, and the 
negroes set to dig up the earth in every direction, to try if this would extirpate them; but vain was all earthly means. The great sum of $\mathcal{L} 20,000$ was offered as a reward to any person who should discover a mode of destroying them; but no plan could be devised, till, in the year 1780 , the wise Disposer of all things, hy sending a most awful hurricane, accompanied by mighty torrents of rain, ridded Granada of this scourge, and at the same time proved most fatal and destructive to many of the other West India islands.

In a tour through the W West Indies by M'Kinnen, * he states, that, in the years $178 \mathrm{~S}$ and 1794 , twothirds of the cotton crop were destroyed by a caterpillar called the Chenille, which is supposed to be the larva of a moth.

Let us turn to our gardens, and sce what ravages are often committed by the larvae of these beautiful animals. The bowers of Pomona are frequently laid waste hy them. The Currant Moth (Phelena grossulariata) frequently destroys whole gardens of this fruit. Lettuces are subject to the attacks of various species of moths, such as the beautiful one called the Tiger, (Bombye cajes of Fabricius,) and the caterpillar of an anonymous one, which is described by Reaumur as commencing at the root, eats itself a domicile in the stem, and their lodges; which so 
completely destroys the plant, that it never cabbages. * The Pot-herb Moth (Noctua oleracea of Fabricius) is no less consuming to this and other esculent regetables. Besides the I'apilio brassica, cabbages are infested with a moth which is equally destructive, called by Fabricius the Noctua brassicn, which does not confine its depredations to the leaves, but penetrates to the very core of the plant, thereby causing its total demolition.

By a wise provision in nature, many of these caterpillars are limited to become the destroyers of specific plants; but there are others whose depredations are universal, laying waste the whole produce of our gardens. The Gamma Moth (Noctua gamma) - so named from having a character represented in gold on its primary wings, exactly corresponding with that Gireck letter-may be numbered among these. In different countries, at certain seasons of the year, this larva commences its work of devastation, and holds up a strong proof of the power of Providence in working great ends by simple means. This insect, though a common inhabitant of Britain, has seldom been known to commit much mischief with us. In other countries of Europe it is far otherwise; for, in the year 1735, it propagated to such an alarming degree, that it overspread nearly the whole of France. Every road was filled with them, tra-

- Reausiur, ii. 471. De Geer, ii. 440. 
velling from one ficld to another. In the kitchengardens their work of devastation was complete, for they loft nothing of the whole tribe of culinary vegetables but the stalks and veins of the leaves. The ignorant populace, conceiving that these pests were poisonous, and cven affirming that fatal effects had followed the eating of them, felt such a consternation, that even in l'aris, for many weeks, not an individual would use pot-herbs in their soups. It was fortunate, however, for France, that these despoilers did not extend their ravages to the corn fields, otherwise a famine would have been the crinsequence.

It has been satisfactorily proved by MI. Reaumur, that so prolific are these insects, that a single pair of them might produce, in the course of one seasm, eighty thousand individuals. How soon, then, might they overspread the world, and devour the entire fruits of the earth, did not the benign Creator of all things see fit to check their progress by a wise provision! The Ichneumon Fly, by depositing its eggs within the body of the caterpillar, become larve, and prey upon its vitals; and by this means the number, which would otherwise be overwhelning, is kept within due bounds.

Caterpillars are great enemies to all kinds of fruit; and the foliage suffers much from the depredations of the larva of the Black and White Caterpillar of the Phalcena grossulariate. Mr Forsyth, in his work on 
fruit-trees, says that a little moth is very injurious to the pear-tree.* "There is a moth which Limneus calls the pest of Pomona, and the destroyer of the blossoms of the apple, pear, and cherry. Certainly this most useful fruit is subject to great havoc from the catcrpillar of the Figure-of-Eight Moth, (Bomlyy. corulocephala of Fabricius,) an insect common to Europe.

In the years 1731 and $173^{2}$, a general alam was caused in France hy the appearance of vast numbers of the larva of a moth nearly allied to the Brown-

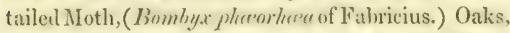
ums, and white-thom hedges, appeared as if hlighted by lightning, for their leaves were totally withered, and dyed of a reddish hrown colour; the caterpillar feeds on one surfice of them only, and that which is left soon becomes seared and brown. Their attacks did not end with the trees of the forest, for they penetrated into the orcharels, stript them of their foliage, and afterwards preyed upon the fruit. So universal was this scourge, that it spread general consternation, and at length an edict was issued by the Parliament, ordirining people to collect and destroy them. But even this means had nearly proved abortive, when, fortunately, a tract of cold weather set in, accompanied by heavy rains, which so completely extirpated them, that it was with

$$
\text { - Page 271. }
$$


difficulty that even a single larva could be met with.*

The Brown-tail Moth has made a conspicuous figure in history, from the great alarm its caterpillar caused to the inhabitants of the vicinity of London in the year 1782. These were so multitudinous, and their devastation was so complete, that rewards were offered for collecting the catcrpillars, and the churchwarden and overseers of parishes were appointed to see them burnt. 'The peasintry and others flocked in with bushels of them from all directions, for the sake of the premium.

In the year 1731, the cuteryillar of the Bomloy.r dispar committed terrible havoc among the oaks of lirance; and in 1797, the larva of the Bomlyy. monacha of Fabricius sally devastated many of the extensive forests in the vicinity of Pareuth, in Bavariat And De Geer informs us that the Noelue brumata of Faluicius is a dreadful enemy to all forest-trees. In various provinces of North America, the woods are entircly stript of their foliage by a species of caterpillar of the moth tribe. This usually happens during the warm season, and often proves fatal to the forest, as the trees, being denuded of their leaves, are totally dried up, and die.

These are among the enemies which make an

- Reaunur, ii. 122.

+ Wieneh, I'crzeich, 8so celition, p. 5.5.

‡ Kalм's Travels, ii. 7 . 
open attack upon the vegetable kingdom, but there are many others which carry on their work of destruction in concealment; among which may be numbered the larva of the Bomlyyx cossus, which insinuates itself into the heart of the willow and sallow, and feeds upon the wood, which it frequently devours so effectually, that large trees are often blown down in consequence of heing quite hollow at heart.

There are other animals of a more insignificant nature, which are enemies to the comforts of man. Reaumur tells us of a little moth, whose larva feeds upon chocolate, and naturally concludes that this could not have been its original food. Leuwenhoek detected a moth which preyed upon two spices, the mace and the nutmeg.

Fven the clothes which we wear, the blankets which cover us at night, and the furs which decorate and add comfort to the fair sex, are not free from these pests. Notwithstanding the utmost care of the housewife in preserving every thing made of woul from the attacks of moths, it too often proves abortive; for these deprulators insinuate themselves no one knows how, and they are too frequently left unnoticed till they have completed their work of destruction. Linneus describes five species of these,- the Tiner restinella, tijretzella, pellionella, sarcitella, and mellonella. Of the first of these we have no particular history, only that it destroys clothes during summer ; but of the others, Reaunur has given a very corn- 
plete account. The Tapestry Moth (Tinen topetvella) is very common in our houses, and very destructive to the furniture of carriages, which is usually more exposed to the air than the furniture of our apartments. They do not construct a moveable habitation like the common species, but, gnawing their way in the thickness of the cloth, weave themselves silken galleries, in which they domicile, and which they render snug and warm, by covering them with some of the eroded wool.* The Skin Moth (T'inea pellionella) is the dread of ladies in all parts of the world, who have too often oceasion to deplore the frightful devastation they commit on the eostly furs of nuffs, tippets, and trimmings. These hidden depredators arc alike the pest of the princess and the poorest peasant of northern regions, sparing neither the ermine nor the bear's hide. Its proper food is fur, but it sometimes also lives on wool. If it is liungry, it will not scruple to make horse-hair its food. Its domicile is not unfrequently formed of this coarse material, which it moves aliout from place to place. So perfect is the work of destruction of these minute animals, that a razor could not more smoothly remove the fur from a hide, than they perform the task with their moutlis.t The Pack Moth (Tinea sarcitella, generally feeds on wool, but

$$
\begin{aligned}
& \text { - Reaumur, iii. p. } 266 . \\
& \text { † Ibid. iii. p. } 59 .
\end{aligned}
$$

VOL. II. 
has been known also to feed on fur, and even hair, when urged by necessity. To woollen clothes they frequently do much mischief, more especially in damp or ill-aired situations. It has been before noticed that the Tinea mellonella commits great havoc in our bee-hives. If, however, it camot get at the wax, it will feed on woollen eloth, leather, and even paper.

There is a caterpillar of a little moth, whose species has not yet been named by naturalists, which feeds on damp old books, and by whose depredations many a volume of antiquity has been lost to the world. The devastation of this minute destroyer is described with much funcy in the following verses :-

\section{TIIE BOOK WORM.}

BY DR PAINELL.

Cove hither, boy; wo'll hunt to-day The Book Wrorm, ravening beast of prey,

Produced by parent earth, at odds, As fame reports it, with the gods. Him frantic hunger wildly drives Against a thousand authors' lives :

Through all the fields of wit he flies, Drendful his head with elust'ring cyes, With horns without, and tusks within, And scales to serve him for a skin. Observe him nearly, lest he climb To wound the bards of ancient time;

Or down the vale of fancy go, To tear some modern wretch below: 
On every corner fix thine eye,

Or ten to one he slips theo by.

See where his teeth a passage eat;

We'll rouse him from the deep retreat.

But who the shelter's foreed to give?

'Tis sacred Virgil, as I live !

From leaf to leaf, from song to song,

IIe draws the tadpoto form along,

He mounts the gilded edge before,

He's up, he scuds the cover o'er;

IIo turns - he doubles - there ho past,

And here we have him caught at last.

Insatiate brute, whose teeth abuse

The swectest scrvants of the muse !

(Nay, never offer to deny,

I took thee in the fact to fly.) :

His roses nipt in every page,

My poor Anacreon mourns thy rage.

By theo my Ovid woundal lies;

By thee my Lesbia's sparrow dies;

Thy rabid tecth have half elestroy'd

The work of love in Biddy Floyd;

They sent Belinda's locks away,

And spoil'd the I3louzclind of Gay.

For all, for every single deed,

Relentless justice bids theo bleed.

Then fall a victim to tho Nine,

Myself the priest, my desk the shrine.

Bring Homer, Virgil, Tasso, near,

To pile a sacred altar here:

Hold, boy, thy hand outruns thy wit;

You reach'd the plays that Dennis writ;

You reach'd me Philjp's rustic strain-

Pray take your mortal bards ngain. 
Come, bind the victim-thero he lics, And here, between his num'rous eyes, This venexable dust I lay, Frod manuscripts just swept away.

The goblet in my hand I take, (For the libation's yet to make,) $A$ health to pocts I all their days May they have bread as well as praise; Sense may they seek, and less cngrge In papers fill'd with party rage. But if their riches spoil their vein, Yo muses, make them poor again.

Now, bring the we:pon-yonder bladeWith which thy tuneful pens are made. I strike the scales that arm thee round, And twice and thrice I print the wound; The sacred altar floats with red, And now he dies, and now he 's dead.

There is hardly a thing on earth free from the attacks of moths, or other insects. Our museums, which present the finest specimens of insects, plants, animals, and birds, often fall a sacrifice to these destroyers; among which may also be ranked the Tinea insectella.

Ulloa mentions the maggot of a kind of moth, which is peculiar to Carthagena, and called there the Comegen. It is so extremely minute that it is not discernible to the naked cye. It destroys all kinds of household stuff, except solid metals. A single night has been sufficient for these little depredators to destroy the entire goods of a warehouse, reducing 
bales of merchandise to dust without their external appearance or shape being altered; and it is only when they are handled that the merchant perceives the wreck of his property.*

To check the superabundance of species which would, in the course of time, overrun the earth, it has been wisely ordered, that one species shall prey upon another. The destructive larve of the Bomby.x villica, and that of other species of moths, become a prey to the larva of various species of the Ichneumon Fly, which deposits its egg within the body of this catcrpillar, where it remains, preys upon its interior, changes to the chrysalis condition, and emerges when it has assumed the perfect or imago state. The Colosome sycophanta, an animal of the Beetle kind, often takes up its station in the nests of the Bombyx processionea, (the Processionary Moth,) and other moths, and sometimes gluts itself so much with levouring these caterpillars, that it is nearly ready to burst.

- Ullod, i. 67. 


\section{CHAPTER II.}

\section{DIRECT BENEFITS FROM MOTHS.}

A moNG the direct benefits derived from insects, it may be noticed, that the catcrpillar of the Great Goat Moth, (the Bombyx and Cossus,) was fattened with flour by the luxurious Romans, and considered by them as a great delicacy. *

Mr Kirby says, " No insects are more numerous in this island than the caterpillars of Lepidoptera ; if these could be used in the steck of food in times of scarcity, it might serve the double purpose of ridding us of a nuisance, and relieving the public pressure." Reaumur suggests this mode of diminishing the numbers of destructive caterpillars, speaking of that of Noctua gamma, which did such infinite mischief in France in the year 1735.t If, however, we take to eating caterpillars, I should, for my own part, be of the mind of the red-breasts, and eat only the naked ones.t. But we will see that there is some

- Pliny, Itist. Nat, i. xvii. c. 24.

+ Reaumur, ii. 341 .

† RAx's Letters, 135. 
encouragement from precelent to make a meal ut the caterpillars which infest our eabbages and cauliflowers. Amongst the delicacies of a Bushies-man's table, Sparman reckons those caterpillars from which butterflies proceed." The Chinese, who waste nothing, after they have unwound the silk from the cocoons of the silkworm, send the chrysalis to table; they also eat the larva of a Sphinx, + some of which tribe, J) Darwin tells us, are in his opinion very delicious; $;$ and, lastly, the natives of New Holland eat the caterillars of a speeies of moth of a singular new genus, to which $\Lambda$ lexander M'Leay, Nsq. (the colonial secretary, and an eminent naturalist,) has assigned characters, and, from the circumstance of its larra coming out only in the night to feed, has called it Nycternbires.

A feast of insects is ingreniously described in Ilcrick's Hespcrides, in the following stanzas, as having been enjoyed by Oheron and his queen Titania.

OBFRON'S FFAST.

Shapcot! to thec the fairy state

I with diseretion dodicate ;

Because thou prizest things that are

Curious and unfamiliar.

- Sparaman, i. 201.

† Sir G. Stavinton's V'oynge, iii. 240.

† Phytologia, 364 . 
Take first the feast-these dishes gone, We'll sec the Fairy court anon. A little mushroome table spred, After short prayer's they set on bread, A moon-parelat grain of purest whent, With some small glit'ring gritt, to eate 11 is choyce bitts with ; then, in a trice, They make a feast lesse grcat than nice. Iut all this while his eye is served, We must not thinke his care was sterved;

But that there was in place to stir IIis spleen, the chiming grashopper, The merry cricket, puling $\mathrm{Hy}$, The piping gnat for minstralsy. And now, we must imagine, first, The elves present, to quench his thirst,

$A$ pure secd-pearle of infant dew, Brought and besweetned in a blew And pregnant violet; which done, Ilis kitling eycs begin to runne Quite through the table, where he spies The hornes of paperic butterflies, Of which he eates, and tastes a little Of that we call the cuckoes spittle; A little fuzball pudding stands 13y, yet not blessed by his lands, That was too coorse; but then, forthwith IIe ventures boldly on the pith Of sugred rush, and eatcs the sagge And well bestrutted bee's sweet bagge; Gladding his pallat with some store Of enits oggs - what wo'd he more? But beards of miee, a newt's stew'd thigh, $A$ bloated earewig and a flic, 
With the red-capt worm, that's shut

Within the concave of a nut,

Hrown as his tootli. A little moth,

Lato fatred in a pieco of cloth ;

With withred cherries, mandrakes eares,

Moles' eyes; to these the slain starg's teares,

The unctuous dewlaps of a snaile,

The broke heart of a nightingale

Orecome in musicke.

This done, commended

Grace by his priest : the ferst is cnded.

Reaumur has suggested, that it is probable that water colours, of beautiful tints, might be obtained from the fieces of the larva of the common Clothes Moth, which retains the colour of the wool they have eaten with undiminished lustre, and mixes easily with water. To get a fine yellow, blue, red, purple, green, or any other colour, it would only be necessary to feed the larve with cloth of the tint required.*

But of all the benefits to be derived from the papilionaceous tribes, none can equal that of silk, from which is made the richest of dresses, for the fair sex of almost all civilized countries, and which adds a lustre to courts themselves; and, whether we estimate it on that account, or for the importance of its manufacture, in giving employment to thousands of individuals, it must be admitted as a

- Reaumur, iii. 95. 
singular blessing bestowed by Providence on man, by simple and natural means.

All the silk produced in Europe, and the greater proportion of that which is so extensively manufactured in China, is the procluce of the common Silkworm, the larva of Phalema (Bomlyyx) mori. In India, great quantities are procured from the cocoon of the larva of moths of different species. The most productive of these is the T'usseh and Arrindy Silkwornıs. 'They are both inhabitants of Bengal. The first of these, the Phalana, (Atocus I'ap)lin of Linneus,) has been found so plentifully from time immemorial, as to have furnished an abumdant and constant supply of coarse, dark-coloured, strong silk. This is woven by the natives into a cloth, which they call Tusseh-doot-hies-a favourite and durable attire of the Brahmins, and several other sects. It has the advantage of being both a light and cool wear ; and, from the length of time it lasts, it proves in the end to be remarkably cheap. It is singular that this useful commodity has not found its way into the south of Europe, or the intertropical countries of America, being artmirably fitted for these climates. This is a proof, among many which might be allueed, of the tardy progress of improvement, proceeding too frequently from a bigoted admiration of ancient customs.

The silk of the Tusseh Worm is durahle in a remarkable degree; for it discovers but little symp- 
toms of decay after being constantly worn for nine or ten ycars. These insects, which feed upon the Jugube tree, or Byan, of the Hindoos, and also of the Terminalia alata glabra of Roxburgh, called by the Ifindoos Asseau, are guarded by the natives with the most unwearied solicitude; for, by day, they are the prey of crows and other inscctivorous birds, while, by night, they are eagerly sought after by bats.

The Arrindy Silkworm (the Phalmna Cynthies of Drury) spins cocoons of an extremely soft texture. The filaments are so excessively delicate and glossy, that they cannot be unwound by the ordinary process, but are spun in the same manner as cotton; and afterwards manufactured into a loose and coarsc kind of white cloth. The durability of this thriftless looking material exceeds all credibility - a lifetime being barely sufficient to wear out a dress made of it. The natives use it for packing sheets, as well as clothes.

Besides the species above named, there are others to be met with in China, from which silk is procured; for we find, in Young's Annals of Agricullure, ${ }^{*}$ an extract of a letter, from which it appears, that a recent introduction of them from that country into India has taken place. "We have," says the writer, "obtained a monthly Silkworm from China, which I have reared with my own hands, and in

- Annals of Agricullure, rol, xxiii. p. 235. 
twenty-five days have had the cocoons in my basins, and by the twenty-ninth or thirty-first day a new progeny feeding in my trays. This makes it a prize to whoever would undertake the cultivation of it."

In the Philosoplical Transactions, ${ }^{*}$ we have an account of a moth found in America, which produces a cocoon, heavier and more productive than that of the common Silkworm; it, besides, has the quality of being greatly stronger, for it has been found by Latreille, that twenty filaments will bear an ounce more weight than the same number of ordinary silk. $\dagger$

The inhabitants of Chimpaucing, Textula, and other places of South America, manufacture stockings and handkerchiefs from the ovate nests of caterpillars, which feed on the leaves of Psydizm pyniferun and pomiferum. $\neq$ These nests are eight inches long, and of a gray colour.

In an extensive and fertile valley, 10,500 fect above the level of the sea, in the mountains of Santarosa, at Valladolid, one of the twelve intendencies into which Mexico is now divided, upon the shrub Arbutus Madrôna, as well as other trees, Baron Humboldt observed immense numbers of

- Phil. Trans. for 1759, p. 54.

+ Latrexle, Irist. Nat. xiv, p. 150.

$\mp$ Annals of Botany, vol. ii. p. 104. 
nests similar to those last described. They, however, differed so fur, in being of a dense tissue, very similar to Chinese paper, of the most immaculate and shining whiteness. They were formed into scparable tissues, the innormost being thinner than all the others, exceedingly thin and pellucid. These were named the Bombyx Medrôna, from the plant on which they feed, by Humboldt. They are social caterpillars, and these nests are formed by their united labours. The manufacture of this silk was an object of much commercial interest among the ancient Mexicans, at least as far back as the time of Montezuma, king of Mexico, who reigned in the year 1511. These people pasted together the inner layers, to form a thick, white, and glossy pasteboard, for the purpose of writing. Humboldt says, in his Political lissay on New Spain, * that handkerchiefs are manufactured from this silk at various places in the intendency of Oaxaca.

Indian grass used by anglers, is said to be procured by the Chinese from the gum and silk receptacles of several of the lepidopterous larva.

Most of the caterpillars of lutterflies and moths are formed so as to spin silk. This is of various degrees of texture and colour, according to the species; and we have already seen, that Nature has endowed them with this ficulty for the protec-

- Annals of Botany, vol, iii, p. 59. 
tion of the pupa, and has also enabled them to construct coverings for their own comfort and safety, after their exclusion from the egg. We have shown that, by spiming a thread, they are also enabled to descend from a branch to the ground in safety, and also to return to a tree by the same filament. The construction of their feet is admirably adapted for this purpose. Each of the six fore-legs is provided with a hooked claw, as in the following figure:

FORE-LEG OF A CATERPILLAR, GREALY MAGNIFIED,

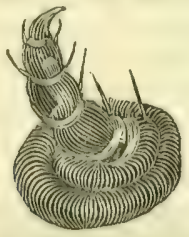

The whole interior conformation of silk-spimning citerpillars differs widely from that of warm-blooded animals. They have no heart, but in its stead, a long tubular dorsal vessel, running along the back, which, according to Malpighi and other comparative anatomists, has a pulsation varying from twenty to a hundred beats in a minute: but neither Lyonnet nor Cuvier could discover any vessels branching from it, so that, if analogous to blood, it has no 
circulation. Another important distinction between these caterpillars and vertebrate animals is, that they have no brain; their nervous system consisting of ganglions, or the nervous filaments united at intervals, by little knobs. Neither have they lungs, and they breathe by means of small spiracles, or air holes, placed in the middle of the segments, or rings, of the caterpillar, on each side; these argain communicate, and end in the throat by means of tubes. The spimning apparatus is situated near the mouth, and connected by means of long slender ressels with the silk bags.

The external tube by which the silk is produced, has been termed the spimneret, which Reaumur supposes to have two orifices for the extrusion of the silk, which, however, the accurate Lyonnet found to unite before their reaching the termination of the tube ; and discovered that it was conposed of alternate slips of horny and membranaccous substance, - the one intended for compressing the filament into small diameter, and the other for enlarging it at the will of the animal. Its point is truncated like the nib of a pen, which admirably adapts it for applying it to any object. Lyonnet has given full and satisfactory delincations of dissections of all the silk-spinning apparatus of moths. The species he selected for this purpose was the caterpillar of the Goat Moth, P. cossus. 


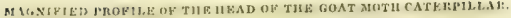

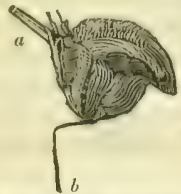

The spinneret is seen at $a$, and the throut, or trachea, at $b$. The shape of the tube itself will be better understood by the following figure, which is magnified 22,000 times.

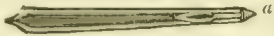

The point of the spimeret is represented at $\alpha$. The following greatly magnified view of the Sabium, or lower lip of the Groat Noth Caterpillar, will show the relative situations of the different parts of the spinning apparatus :

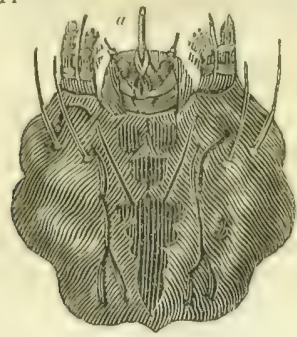


The silk tube, or spinnerct, is seen at $\alpha$. "You may sometimes have seen," says the $\Lambda$ bbé de la Pluche, "in the workshops of goldsmiths, or gold wire-drawers, certain iron plates, piereed with holes of different calibre, through which they draw gols and silver wire, in order to render it finer. The Silkworm has umler her mouth such a kind of instrument, with a pair of holes, (united into one on the outside, ) through which she draws two drops of the gum that fills her two bags. These instruments are like a pair of distaffs for spinning the gum into silken thread. She fixes the first drop of gum that issues where she pleases, and then draws back her hoad, or lets herself fall, while the gum, continuing to flow, is drawn out and lengthened into a double (single, according to Lyomet) stream. Upm luing exposed to the air, it immediately loses its fluidity, becomes dry, and acquires consistence and strength. She is never deceived in adjusting the dimensions of the (united) apertures, or in calculating the proper thickness of the thread, but invarially makes the strength in proprortion to the weight of her body.

"It would be a very curious thing to know how the gum which composes the silk is separated and drawn off from the other juices that nourish the animal. It must be accomplished like the secretions

- According to the discovery of Lyonnet.

VOL. It. 
formed by glands in the human body. I am therefore persuaded, that the gum bags of the Silkworm are furnished with a set of minute glands, which, being impregnated with gum, afford a free passage to all the juices of the mulberry leaf corresponding with the glutinous matter, while they exclude every fluid of a different quality." * If this theory be correct, then it applies equally to all the silkspinning caterpillars.

- Spectacle de la Nature, vol. i. 


\section{CHAPTER III.}

ON TIIE FOOD OF MOTIIS.

Tine food of the Phaliena next demands our attention. The Tinea vesinella and the Minute Moth feed on the resinous or otlier excretations, exuded from trees; others of the Tinea eat only the parenchyma, never touching the cuticle. The Noctua ochraceaga eats the pith alone, while others select the pollen and honey secreted in the nectaries. The larre of different $T$ 'ineere, as before observed, feed on wool ; but it is wiscly ordered by nature, that unwashed wool is never touched by them. The Tinen described by licaumur, devours the highest perfumed chocolate; and the Wax Moth catcrpillars will, for want of that substance, eat paper, wool, wafers, \&c. The larve which feed on vegetables, seem to be less general in satisfying their appetites, although it is likely they can subsist on various kinds of food in cases of necessity. Many species of lepidopterous larve are polyphagous, feeding on almost all kinds of plants. Reaumur, however, asserts, that if a caterpillar has fed for some time on any particular plant, although not the one appropriated to it by 
nature, it will rather die than feed upon another kind, although this would have been quite agreeable to their palate prior to eating that other plant accidentally." We must also keep in view, that insects feed on different kinds of food in their various stages of existence, from the larva, to the imago condition, In the first state, they feed either on the leaves or other parts of plants, while the perfect insect feeds almost exclusively on the nectar of flowers.

Some of the Phaliena feed during the day, while others feed only at night, or in the evening. The Nycterolius, mentioned by MFA'Leay, as inhaliting New Holland, lay up their store of provisions during the night, and feed on it through the day.

The larve of papilionaceous insects far exceed all others in the quantity of food they consume. They are fumished with jaws, which are admirably adapted for gnawing leares, and act somewhat in the manner of shears.

Nature has endowed many of the animals of this order with wonderful powers for providing themselyes with habitations, and these frequently constructed in a manner admirably calculated for the comfort "of the resident.

The Tine Hilkella, Clevkella, and others, are termed the subcutaneous larre, from their feeding upun the parenchyna included between the upper ani under cuticles of the leaves of plants, of lilac,

- reaunur, ii. 32t. 
dandelion, and various other species. These minute animals not only feed on leaves, but also dinicile within them, although not thicker than a sheet of paper. The zigzag, curved, and concentric lines, which are common in the plants above named, are the work of these larvæ. The white appearance of the lines is owing to the pulpy sulstance being removed. At the end of these winding passages, there is usually a minute dark-coloured speck at the termination of the labyrintl-like lines, which is the habitation of the tiny miner. So minute, indeed, are these larve, that a single leaf of dandelion may be considered as a vast tract of land to a larger animal, for it requires several weeks for them to traverse it.

Nothing can exceed the gorgeous attire of some of these little miracles of nature. She seems to have lavished her most splendid tints, fancifully arranged, in combination with sparkling bands and sputs of golden, silvery, and peally lustre. These, however, only become pereptible by the aid of a strong lens. If these animals were formed on a larger scale, they would far exceed every other creature for splendour of decoration. It may be asked, Why is sucir richness of clothing lestowed on creatures so insignificant? The answer is, that it has pleased Creative Wisdom to hold them up to man as a lesson of humility, to show that even the mostinsignificant worm is robed in a habit with which all his art cannot vic. 


\section{CHAPTEIR IV.}

ON THE IABITATIONS AND ARCHLTECTURE OF MOTHS.

Turere is not a more interesting or remarkable department of our inquiry than the habitations and architecture of the tribe of moths. They are endowed. with an unerring foresight or instinct, by which each species forms for itself a nest or habitation, constructed, in many instances, upon the most philosophical principles. The Linnaan genus Phalcena, or Moth, contains a vast number of species, scarcely two of which build nests alike.

The caterpillars of the $\boldsymbol{N}^{\text {rycterobius, }}$, before alluded to as an inlabitant of New Holland, excavate for themselves holes in trees, especially in that splendid tribe, the Banksia ; and to which they frequently prove very destructive, owing to the numerous cavities they make. They have a most ingenious method of defending the entrance of their abode from the attacks of the Mantes, by a kind of trapdoor of leaves and excrement, interwoven with silky filaments, which they fasten firmly at top, but leave unattached at the 
bottom, for the free egress of the inmate. They never quit their abode during the day, but regularly set out, at sunset, on their perambulations in seareh of food, and drag to their domicile, one by one, such leaves as they feed upon, which they consume at their leisure. One species carries the leaves of Bankisia serrata, by the fuotstalk, to its cell, the don" of which it opens with its tail, and enters backwarls, dragging the leaf after it.*

The lave of the Tortrix and Tinea form the le:tves of plants, on which they feed, into comfortable and convenient habitations. Some species of these, less serupulous, make more superficial abodes, by simply connecting, in an irregular packet, a quantity of leares, united by a few of the silken threads which they spin themselves, and there live in solitude; while others, still less ambitious, confue themselves to a single leaf, with one side simply folded over the wther. Others, again, live in a sort of roll, which is varied in shape, according to the peculiar taste of the species, some cylindrical, others conical, like a grrocer's sugar paper, constructed with much nicety, closed at the broad end, and left open at the smaller one, for the ingress and egress of its inhabitant. It is impossible attentively to contemplate these little domiciles without our admiration and wonder being awakened; and we naturally marvel at the mecha-

- Leiwiss, Prodlromes of Entomology, p. B. 
nical power by which it has been constructed, and how an insect, possessing neither hands nor fingers, could roll together a leaf, and keep in that roll, until it is secured by the silken filaments which completes its binding. The following is the mode in which it is constructed:-The little architect commenees his operations by first attaching a series of' silken filaments from one edge of the leaf to the other. These threads are pulled by the feet of the caterpillar till the sides come in contact, when he linds them firmly by shorter threads. It not unfrequently happens, that the stronger nerves of the leaves resist the efforts of the tiny architect, in which ease he proceeds to gnaw them at intervals, till they are so weakened, as to be luent with perfect (ase. If this is only instinct, it makes the nearest possible approach to reason; for man himself, in his untutored state, could not act with more wisdom. A very different procodure is necossary where a ('mital, or horn-shaped, receptacle is wished, which is not framed with a whole leaf, but with a long triangular portion cut out of its erlge. The caterfillar, in this case, fixes himself on the uyrer surface of the leaf, and cuts, in a regular and systematic style, with his jaws, the piece necessary for his purpose, without, lowverer, (ntirely diviling it from the other portion of the leaf, whinh maturally forms the base of his superstructure. This triangular fillet lun wints round as he procecrs; and, as it generally 
stands in a perpendicular position, it is necessary, by some mechanical contrivance, to elevate it. To obtain this end, he puts in operation the same sort of contrivance as man would employ with an inclined obelisk, by attaching to the point of the pyramid threads, as man would do cables, and then, applying the weight of his own body in opposition, raises it to the perpendicular.*

A species of moth, which feeds on the lilac, forms a habitation for itsclf within the leaf of that trec. This it rolls up at the point of the leaf, by commencing at one end, and fixing and pulling its threads till it becomes nearly the shape of a scroll of parehment. Another species pursues a different method with lilac leaves. By a process similar to the above, it contrives to bring the extreme edges of the leaf together in the manner of a hollow tube, leaving it open at the hottom and point for its egress, as represented in the following figure:-

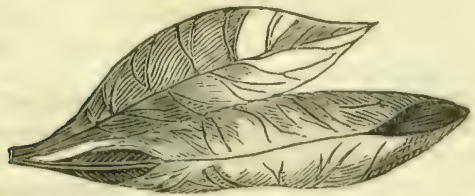

The Small Green Oak Moth, (Tortrix viridana,)

- Bonnet, ix, 188. 
an insect of a fine green colour, pursues a similar mode of constructing a habitation with the first mentioned of the lilac caterpillars, but differing in one particular, that it works on the under side of the leaves, in place of the upper surface, pulling the leaf lackwards and downwards, and fixed steadily hy small external cables, as represented bclow.

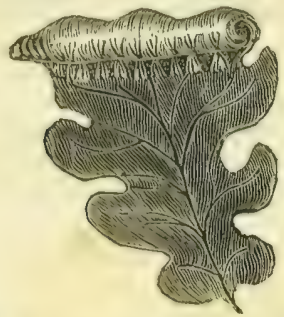

There are a great varicty of plants, whose leaves form the habitations of different species of larva,the nettle, the mallow, the sorrel, the willow, the plantain, the eypress, \&c.

Among those which are called Carpenter Caterpillars, the Goat Moth (Cossus ligniperda) is one of the most remarkable. This species abounds in Kent, and many of the southern counties of England, where it proves exceedingly destructive to oaks, poplars, willows, elms, and other trees. It insinuates itself through the bark when very small, and eats into the 
very centre of the wood, where it forms extensive spiral excavations. An idea may be formed of the extent of these, when it is mentioned that this caterpillar grows to a very large size, not unfrequently four inches in length, and upwards of half an inch in breadth, exclusive of its limbs.

When the cold wcather sets in, it excavates an ample hollow in the trec, sufficiently large to contain its body coiled up. Professor Rennie mentions having found one, in 1827, in its winter nest, which was enveloped in "a fabric as thick as coarse broadcloth, and equally warm, composed of the raspings of wood scooped out of the cell, united with strong silk." The following is a figure of one of these in its winter nest:

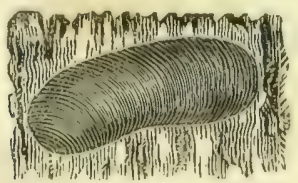

Some other of the Tinee display still greater sagacity, in construeting habitations for themselves; those which feed upon the leaves of the oak, elm, apple, and rose trees, on the under sides of which they may be frequently found during summer, particularly excmplifying this. They eat the parenchyma - Insect Architecture, p. 190. 
between the membranes, composing the upper and under cuticles of the leaves. These nests are of an oblong shape, and so artfully joined with silk threads, that the seam is hardly discernible, even with the assistance of a powerful microscope; they are of a hom shape, cylindrical in the middle, with the anterior orifice circular, and the posterior opening of a triangular form. If these habitations were cylindrical throughout, the contraction of them would be an operation requiring comparatively very little nechanical skill; but, as the two ends are quite different, so there is a necessity for both sides being dissimilar in their curvatures; and we have the assurance of Reaumur, that they require the same nicety of imitation and junction as the different pieces of which the back of a coat is composed.

Speaking of insects of this tribe, Mr Spence says, "Their proceclings I had the pleasure of witnessing a short time since upon the alders in the Hull Botanic Garlen. More ingenious than their brethen, and willing to save the labour of sewing up two sides in their dwellings, they insinuate themselves near the edgre of a leaf instead of in its middle. Here they form their excavation, mining into the very crenatures, between the two surfaces of the leaf, which, being joined together at the edge, there form one seam of the case; and, from their dentated figure, give it a very singular appearance, not unlike that of some fishes, which have fins on their backs. 
They are necessarily forced to cut and sew up the opposite side; but, even in this operation, they show an ingenuity and contrivance wortliy of admiration."

Those species of 'Tinee" which excarate their habitation in the middle of the leaf, separate entircly the two surfaces that compose it, before they commence joining them together; and the serrated incisions made by the mandibles have the tendency to support the opposite edges, by interlacing with each other, so as to support the disjoined portions until they are properly secured. Those Tinete, however, which eat out their habitations from the edge of a leaf, cannot proceed upon the same principles, for, if they were to scparate the inner side before they had joined the two pieces, both the architect and his building would come down. Befure making the incision, therefore, they baste (to adopt a phrase used by tailors) tongether in remote points the two membranes on that side. Then, by thrusting out their head, they separate, with their forceps, the intermediate portions, while they take care to aroid touching the larger nerves of the leaf. When this operation is gone through, they proceed to sew up the detached sides in a more regular style, while they only intersect the nerves, which completes their ingenious task.*

Some other caterpillars form their dwellings en-

- Rrausur, iii. 100.120. 
tirely of silk, and similar in its general plan of construction to that last described, except in point of the material with which it is composed, and, like it, feeds on the parenchyma of the leaf alone. Peartrees are much infested with these minute larvæ; and, in spring, they frequently beset the whole under side of the leaves with their abodes; these are of a downy russet colour, about a quarter of an inch above the surface of the leaf, and have greatly the rescmblance of spines. That they are the domiciles of these minute larve can be easily proved, for if one of them is detached from the leaf and squeezed, a minute caterpillar will be ejected, with a black head and yellowish body. If the spot from which this habitation was remored be examined, it will be found to have a round excavation in the cuticle and parenchyma of the leaf, the size of the end of the tube. The animal, like the Arab of the desert, has the power of moving its little marquee from one place to another, and thus eating away the part immediately beneath it. All the little seared specks to be seen on the leaves of pear-trees, are the remains of their destroying powers. * The tube in which the larva dwells, and which is indispensable to its existence, is of its own manufacture, spun from silk emitted from its mouth, so soon as it energes from the egg. When the creature enlarges in size, it increases the

- Forsytu on Fruil-Trces, 4 to. 271. 
dimensions of its abode, by cutting it asunder in a longitudinal direction, and then introduces a slip of new materials. "But the most curious circumstance in the listory of this little $\Lambda \mathrm{rab}$, is the mode hy which it retains its tent in a perpendicular posture. This it effects partly by attaching silken threads from the protuberance at the base to the surrounding surface of the leaf. But, being not merely a mechanician, but a profound natural plilosopher, well acquainted with the properties of air, it has another resource when any extraordinary violence threatens to overturn its slender turret. It forms a racun in the protuberance at the base, and this as effectually fastens it to the leaf as if an air-pump lad been employed! This vacuum is caused by the insect's retreating, on the least alam, up its narrow case, which its body completely fills, and thus leaving the space below free of air." If one of these cases is detached from the leaf, this fact may casily be perceived. If the cell is suddenly scized, while the insect is at the bottom, it will be found readily pulled off, as the silken cords give way to a very slight force; but, if it is done more gently, the insect gets time to retreat, in which event the case will become so firmly fixed, that some force will be required to remove it. "As if aware that, should the air get admission from below, and thus render a vacuum impracticable, the strongest bulwark of its fortress

- KinBy and Spence's Introduction, i. 457. 
would be destroyed, our little philosopher carefully avoids gnawing a hole in the leaf, contenting itself with the pasturage afforded by the parenchyma above the lower epidermis; and, when the produce of this area is consumed, it gnaws asunder the cords of its tent, and pitches it at a short distance as before."**

When the animal attains its full growth, it assumes the pupa state; and, after its appointed period of confinement, bursts its casement, and issues forth a small brown moth, with long legs, the Phalona Tinea Serratille of Linné.

Sir James Smith, late president of the Linnæan Society, had in his cabinet the case of a lepidopterous larva, which was composed of the spines of some species of Mimosa; these were ranged side by side, so as to furm a very elegant fluted cylinder. The male caterpillars intermix with the pieces of twigs, which are less closely and regularly arranged, bits of dried leaves, and other light materials. The larva of the Bombyx vestite forms a similar habitation of pieces of small twigs; and the Tinea viciella covers itself with short pices of the stems of grasses, placed transversely, and united by means of silken filaments into a pentagonal or hexagonal case. Reaumur descrilses the domicile of a caterpillar of the same family, which is composed of square pieces

- Kirby and Spence's Introduction, 1. 4i7.

† ANDEnson's Recreations, ii. 409. 
of the leaves of grasses, united at one end only, and overlapping each other like the imbricated tiles of a roof; and he notices another, similarly constructed, of minute portions of the twigs of broom.*

The Tines lichenum forms pieces of lichen into a house, resembling in shape some of the turreted snail shells. Mr Kirby noticed many of them on an oak at Barham, in June 181\%. Another caterpillar of the 'T'inea, which likewise feeds on lichens, does not frame its labitation of them, like the last-mentioner species, but comnects together, with silken cement, grains of stone, from walls where the lichens grow. There is a curious memoir on the subject of these insects in the Transactions of the French Academy, by M. de la Voge. That gentleman supposed that, because these larve were found in such abundance on mouldering walls, that they possessed the property of eating stone, and considered them as the means which Time employed to carry into effect his slow but certain destruction of all things; but which ought rather to be attributed to atmospheric erosion. Reaumux justly remarks, that these larvae are so small, and the particles of which their covering is composed so minute, that ages were not sufficient for them to produce any perceptible impression. They have been termed Stone-mason Caterpillars;

- Renumur, iii. 148-9.

+ Trans. French Acad, x. 458.

VOL. II. 
their tents are shown in the following figure. Those adhering to the stone at No. 1, are the size of nature, and $\mathrm{N}_{0} .2$, is a magnified representation.

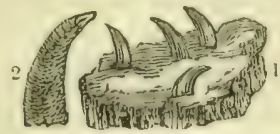

Various caterpillars, which produce their habitation from pure silk, are not satisfied with a single coating of it, lut spin for themselves an upper garment, resembling a eloak, open at one side, which heaumur appropriately terms "Tcignes ì fourreu i manteau." A remarkable peculiarity of these coverings is, that instcad of being fabricated of a firm and close texture, they are composed of imirirated, transparent seales, like those of a fish.

The dwellings of the larve above deseribed might, with more propriety, be rather termed clothing than houses, as they fit the animal like a vestment. This is more especially the case with some of the Tincer, (or Clothes MLoths,) which cover themselves with a coat of the very same materials as mankind, of wool or hair curiously interwoven together. Dr. Paley asserts, that "the lumun animal is the only one which is naked, and the only one which can clothe

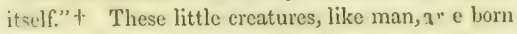

- Reausur, iii. 206.

+ Natural Thcology, 1., 230, 3vo calition. 
naked ; and, like man, are capable of covering then selves, thus contradicting the Doctor's theory. Nay, these larvx, which man in general looks upon with contempt, are endowed with ingenuity in some respects superior to his own; for the moment they have inhaled the breath of life, they prepare to cover themselves, and this they effect in a manner more consonant to their condition, than the dress of savage man is to his state. The shape of the habiliments of larvæ consists usually of a cylindrical tube, open at both ends. These are woven from wool or hair, ingeniously cut down by the larva of the Tines, which is compactly incorporated with silk drawn from their mouths, generally made more comfortable and suitable to their tender skin by a lining of the softest silky texture.

\section{case of trie crotures noth, (Tinea pellionelle.)}

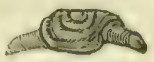

These they wear from infancy to maturity; wisely disregarding change of fashion, while they have comfortable and convenient coverings. They, no doubt, require to be enlarged as the animal increases in bulk; and this they accomplish with the greatest dexterity and accuracy. To lengthen their covering is an easy matter, by adding a ring of hair or wool to each end; but when too narrow, the task is 
somewhat more difficult. But they set about it in a manner similar to the mode employed by a tailor, by slitting the case open from one extremity to another, and then inserting a piece of the breadth required, with the utmost accuracy. The cut is, however, not made from one end to the other at once, as in that event the sides of the case would get too far apart, and lcare the tenant naked. It therefore only cuts each side halfway down, as shown in the following figure:

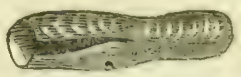

and, after having inserted the necessary addition, proceeds to cut the other half, and fills it up in the same manner. In this way four separate pieces are inserted. As the coloux of their covering always depends upon the colour of the stuff from which it is taken, it not unfrequently happens, that when the animal has made its first envelope of blue, it may afterwards make its way into a red stuff, and consequently, the additions will be of that colour, giving the creature the appearance of a little harlequin.

The injury sustained by mankind from these minute depredators, does not proceed from the quantity which they consume as food and clothing alone; for, as they proceed along the surface of fur or woollen stuff, the long hairs impede their progress, 
and, being possessed of natural instruments whereby they are enabled to cut a passage for themselves, they smooth the surface of every obstacle in their route.

Those who wish to investigate the singular phenomena presented by these minute beings, have only to leave an old coat, or other piece of dress, in any dark or damp situation, and it will soon become the retreat of the Tinea, and afford ample opportunities for studying their habits. 


\section{4}

\section{CHAPTER V.}

OF SOCiABLE CATERPILLARS, On THOSE WHICH LIVE IN SOCIETIES.

WE shall now proceed to describe the habitations of a different tribe. Most individuals must have observed, during their walks through a garden or orehard, the fruit-trees disfigured by what would appear a strong and thick spider's web. If these are attentively examined, it will be found that they difler matcrially in their construction fiom those spun by spiders, for they enclose on every side an angular space, and will be found filled with the larve of Bombyx chrysorrher. The web is the produce of their united labour, as they are gregarious animals, delighting to dwell in society. The female deposits from three hundred to four hundred eggs, and, as soon as these are hatehed by the genial rays of the sun, the whole community commence their operations. Their first procedure is very simple: they form a sort of coat of the single leaf upon which they are hatched, over which they construct an awning, 


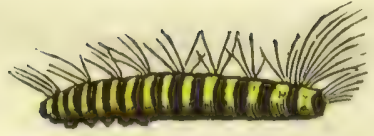

72.

2ABVA $\triangle N D$ CATERPILLAR OF TUE PINK CNDER-WING MOTIT. Phitcena Jacobea,-Brstais. 

composed of silken filaments, stretehed frum one em! to the other. In some eases, where the colony is numerous, they construct two leaves in this manner, where they reside for some days, until they have gained sufficient strength to fit them for a larger and more complete work, sufficient to contain the whole colony. In the formation of their new habitation, they do not adort any symmetrical shape, except that it is always angular; sometimes it is flat, and frequently roundish. Their first operation is to spin a close and well united silken wels round the end of two or three twigs, and the leaves attached to them, adjoining each other, and as close as pussible in their original abode, taking eare that it will be large enough to aecommodate them when they shall have arrived at maturity. They then proced to divide: the interior into apartments, by partition walls of woven silk, and an appropriate door is left in etch. These are their retreats in rainy or stomy weather ; for, when the day is fine, they spread themselves over all the aujoining leaves, for the purpose of feeting. These creatures are sure prognosties of atmospheric changes; fir some considerable time before barl weather, they are sensible of its apruroach, amel specdily retire to their cells. In these, also, they repose during the periods when changing their skins. As soon as winter sets in, the whole society shut themselves up in this abode, which, by repeated layers of silk, they have randered impervinets to the 
rain and wind. Here they continue in a torpid state till the beginning of April, if the season is favourable, when they are recalled into action by the genial wamth of the sun, and they quickly crawl abroad, and devastate all the young and tender leaves in the neighbourhood of their domicile. To prevent the possibility of their structure being damaged by the shoots inside, they gnaw all the shoots of leaves off as soon as they are formed.

By this time the eaterpillars increase greatly in size, which obliges them to add to their dwelling.

The caterpillar of the Processionary Moth (Bombyx mocessionea) constructs its nest in a different manner from the above, although the materials are the same. These larve feed universally on the leaves of different species of oak. They always attach their house to the trunk of the tree in place of the branches, and fiequently at a considerable height from the ground. It is formed like a large irregular knot, or protuberance, and at a distance is frequently taken for a bunch of lichens, as the colour of the silk of which it is composed is gray. This nest is sometimes cighteen inches in length, and six in breadth, swelling in the centre about four inches from the tree. The ingenious architects leave only a single aperture for their entrance and retreat. In their young state, the Processionary Moth caterpillar's differ materially in their labits from that of the Bombyx chrysorthas. For while very young, they have no settled or general 
habitation; they content themselves with occupying temporary tents, till they have arrived at above twothirds of their adult size. They then congregate, and, by their united labours, construct the large habitation above described, where they dwell in great harmony, until they have gone through the purgatory of their chrysalis state, when they assume their perfect condition.

The Bombyx placorrhea, neustria, and many others, construct similar nests ; but it is unnecessary to enter into a detail of these.

leaumur gives an interesting account of the Goldtail Moth, whose catcrpillars are gregarious, and spin for themselves a silken tent. They are of that family of Bombyces, which pull from their bodies the hairs wherewith to envelope their eggs. The moment the larva emerges from the egg, it commences feeding: it is quickly joined by another, which places itsclf alongside the first, until a succession of these reach across the leaf: when this is completed, a second pile is begun, and then a third, and thus they continue to rank themselves till the whole upper surface of the leaf is covered. It seldom happens that a single leaf is large enough to contain the whole community; those who cannot be accommodated pursue the same arrangement on a contiguous leaf. When they have satisfied their hunger, by a simultancous impulse, they set about weaving a habitation for their mutual comfort. This they at first 
construct in a simple style, by a vaulted web, simply covering the leaf they inhabit. In the course of time, however, a larger one is formed, with a plurality of apartments, strong in its texture, and magnificent in it appearance, and capable of protecting them against the inclemency of the weather, and the intrusion of enemies. And with the style of Eastern magnificence, they spin a soft carpeting over every part of the bark of trees, where they may have occasion to tread in search of food. They seldom feed in the parching heat of noon-day, but repose in their tent; here, also, they pass part of the middle of night. It, however, seldom happens that they are all out at one time. In this comfortable retreat they change their skins, and to it they fly for refuge when alarmed. Here, also, they spend the winter in a state of torpor, emerging in spring, feeding again in society ; but alsout the end of May, or beginning of June, they disperse, and, cating for a month in solitude, change their condition into a prepa. It is when these caterpillars finally abandon their nests that they are taken possession of by spiders, which has given rise to the popular, although crroneous belief, that they are the parents of these larve.

The most remarkable of this tribe of insects which live in imperfect socicties, are those whose caterpillars, upon certain occasions, preserve a particular line of march. Bonnet gives an interesting aceount of the Phalcena (Bombyx) neustria, whose cater. 
pillars are of that tribe which march rank entire. They sometimes advance in straight lines, and at others in curves of various inflection. They are of a fiery colour, which gives them the appearance of a cord of gold, extended on a silken fillet, of the most immaculate whiteness. It is when travelling on this carpet of silk, to feed on the leaves of their favourite plants, that this appearance is exhibited. The Pityocampa, another moth which congregates in a common receptacle of pine leaves, united by filaments of silk which they spin, is also of this military order. They follow cach other in a varicty of mazy turnings, which gives the most animated picture of ever varying living wreaths. The whole chain of caterpillars move in unison, and at a proper distance from each other, in the most perfect order; and when their leader stops, the whole halt in an instant.*

A DIYISION OF PROCESSIONARY LART $\mathbb{E}$.

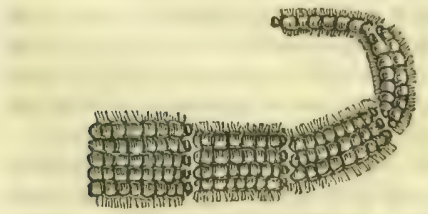

The Processionary Moth affords a still more

- Bonnet, ii. 57. 
amusing picture, when it sets out in quest of food. It is a native of France, and feeds on the leaves of the oak. They live in families of from six to eight hundred individuals. In their earliest stage they have no settled habitation, but pitch their tent wherever their fancy directs; and it is not till they are two-thirds grown that they form a domicile large enough for the whole community, which I have alrcady described. It is generally about sunset that the colony leaves its quarters, and sets out on its excursive rambles. They are led by a chief, who regulates all their movements; three, or sometimes four, of his immediate followers, move in the same line, the head of each touching the tail of his precursor. Their movement is in a sort of pyramidal form ; for after these Indian file, there comes a series in pairs, after them a number in threes, fours, and increasing systematically, till the column is concluded by rows of from fifteen to twenty. This little army (if I may be allowed the expression) proceeds with a steady movement, each animal following in direct line that which precedes it. If their leader makes a turn at any particular point, the whole of his followers arrive at the same spot before they make a wheel. They may be guided in this movement by a particular odour left by the leader on the line of his march. This is not, however, their invariable order of proceeding.

The leader has nothing different in his appear- 
ance from the others, and is in all probability the one nearest the tent when they set out; at least, such is Reauinur's opinion. When he first issues from his retreat, he moves forward about two feet, less or more, according to the numbers of his followers, who now appear from out their cell, and rank themselves in the manner before described, and when this is completed, they move off with the regularity of an amy marching to a band of music.

The larre of the Processionary Bombyx are sometimes, although rarely, seen in the open air at mid-day; in which case they are usually found packed one above another, as if dead; and although they may occupy a considerable space, yet they are not casily discovered, from the surrounding leaves of grass; at other times they are observed lying side by side. In the former of these conditions they are also fiequently found in their habitations. It not unfrequently happens that these families disperse into smaller groups, and never again unite.*

Our enlightencd and scientific countryman, $\mathrm{Mr}$ Skene of Rubieslaw, on an arid coteau above Tolonai, in Provence, France, witnessed a procession of a different species of caterpillar, which marched in Indian file, or in a single row, the interesting account of which I shall transcribe in his own lan. guage :-

- Renumur, ii. 180. 
"I obscrved," says he, "what appoared to me a very slender snake writhing across my path, which, but for the unusual season for these reptiles to appear, should no doult have passed unheeded. Upon examination, however, it turned out to be the orderly emigration of a colony of large caterpillars. They were proceeding assiduously along the rocky path, in a line of march by single files, and so close, that they appeared to have a hold each of his neightour's tail, and the eontinued wave formed by their motion had a very singular effect. The stony surface of the path rendered their progress exceedingly tortuous, and interrupted by much climbing over stones, as they seemed in general more disposed to go over the top of a stone than round its base. When such obstacles occurred, the march, notwithstanding, did not sustain the slightest derangenent, as no troops could mark time with greater precision and patience than the rear of the line, while the front was engaged in elimbing over any obstacle, or the leader had stopped to examine the difficulty ; the fiont, in their turn, tarrying until the rear had succeeded in surmounting the obstruction which the front had just passed. They were twenty-two in number, and nearly of the same size, except one, considerably larger than the rest, whose place was exactly in the centre of the line. The leader, on the contrary, was rather smaller than any of the rest. $\Lambda$ large precipitous stone was in their way; the leader 
reared up, moving his head from side to side, as if gazing at it, or willing to reach some corner; and leading his troop round, he frequently performed the same examination, until they reached a small bush, round the stem of which he ascended, the long line following with perfect confidence, and by means of a branch of the bush, they attained footing on the stone.

"Traversing the stone, the opposite side of which was quite precipitous, and pretty ligh, it became uncommonly interesting to see how this intelligent general would proceed. He examined with accuracy, trying every possible break, during which time the main body remained patiently waiting, and without making the slightest attempt to assist in the examination, which their leader conducted with much activity and solicitude. At length, after having ascertained the pass to be quite impracticable, he resolved upon a countermarch, which was instantly performed with the most surprising regularity. For the whole line in succession advanced to the wheeling point on the brink before they turned, performing the evolution with as perfect precision as the best trained troops, the advaneing and retreating lines passing close alongside of each other, and even climbing the same twig, while the front line descended without eonfusion, passing even over each other's lodies without interruption or hesitation.

"Having completed their descent in the same 
manner as they had mounted, a new line of direction was taken, which, however, was very soon most alarmingly interrupted by the arrival of a woman leading an ass loaded with brushwood, of which some branches trailed along the path. After the passage of this formidable assailant, I returned with the same anxicty to examine the state of my colony, and found that they had suffered materially from the disaster, and were thrown into the greatest confusion. The line of march had been broken; a considerable body still followed the leader with a quickened pace ; others, united in parties of three or four, regularly keeping their position in the rear of each other, while their temporary conductor sought, with evident anxicty, to find out the main body, hastening first to the one side, and then to the other. A good many were scattered singly, and much distressed, seemingly uncertain how to proceed. I took each of them up in its turn, and, with a view to ascertain the range of their vision, placed them at different distances from the main body, with their heads tumed towards it, and I found that they uniformly remained quite unconscious of its presence, until placed within half an inch of each other. They then approached with evident eagemess, and were readily admitted into the line, by the rear halting until they had taken their places.

"I put one of these stragglers in front, with his 
tail to the leader's head, but he pertinaciously refused the honour of conducting the line; a considerable sensation seemed to be communicated through the whole body at this attempt at usurpation, of which they scemed to become aware, but by what means I could not discover. As sonn as this forcel usurper was at liberty, he turned round to the leader. who repulsed him with vigour, and hit at him, upon which he retreated hurriedly along the line, constantly trying to get into his place, lut was hit at hy every one as he ran the gauntlet, till at last a goodnatured friend permitted him to join the line. I then tonk out the large one, who was obviously a stupid fellow, when the rear immediately closed up the breach. I placed him at the head, and used every induecment to make him take the learl, but in vain. Ile seemed much confused by the buflets given to him by the active little Bonaparte whom I wished lim to supplant, so that probably he would have fuiled in regaining his place, had I not given him some assistance, out of sympathy for the distress my experiment occasioned him. He scemed delighted to get into his place again, but was so much confused by the adventure, that he mistook the first sharp turn the line came to, and threw the whole rear into confusion. They broke their line, and much eonsternation and bustle ensucd, until each had replaced his head close to his neighbour's tail.

VOL. II. 
"I now took up the leader, obviously less, though more active and intelligent than the rest, when the alarm instantly spread over the whole line. I expeeted the second to take the command, but he seemed the most distressed of any, and eagerly sought about from side to side; and, in his perplexity, he turned quite around, as if consulting with his follower. The hesitation and confusion was now universal. Various parties broke off as the inpression reached the rear, and sought anxiously ahout, returning again to the line. Having replaced the leader at the head, he instantly took the command, and advancing with confidence, and conducting the whole line in perfect order. When I now interrupted their march, the main hody no longer exhibited their former anxiety and impatience when the leader was removed, lut seemed to wait with perfect composure and confirlence until the obstruction was overeome, which the lender used every means and ingenuity to accomplish. It did not occur to me till I had left these amusing travellers, to try the experiment of placing the leader at the rear, in order to observe how he would bear the degradation, and to ascertain if the head of the column would have been therehy changed."

Besides those larve which conceal themselves, and translorm in their cocoons, there is a tribe which burrow under ground; these have been ealled Earth

- Brewster's Journal of Science, ii. 91. 
Mason Caterpillars. Among them may be ranked the Death's II ead Sphinx, plate Lxxi. Some of these make a rude masonry of particles of earth, united by silk or gluten, varying in form according to the species.

NEST OF THR EAITH MASON LARVA,

(The Water Betony Moth, )

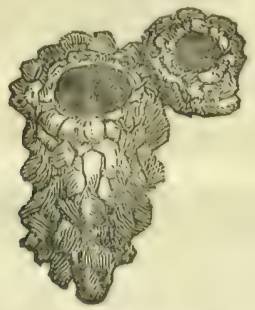

which is generally of an oblong shape, although they are not always uniform. The interior is smooth, lined with a fine tapestry of silk, and polished. 


\section{Genus PIIALENA, or MOTII.}

l'ue antennæ of moths for the most part gradually taper from the base to the tips; the tongue is spiral, and the mouth without jaws; the wings, when at rest, are generally deflected; the flight mostly is nocturnal.

'These fly abroad only in the erening, and during the night, and feed on the nectar of flowers; the larva is active and quick in motion, more or less rylindrical in its shape. These prey voraciously on the leaves of various plants; the pupa is quiescent, more or less cylindrical, pointed at the tip, or at both ends, and is generally enclosed in a follicle. $\Lambda$ u example of the larva of the Pink Under-wing Moth is given in plate 72, under figure; and the pupa of the same Moth, is represented in the upper. figure.

limnxus divides the genus into the following sections :-

Section I. Bosвyx.-The anteme are filifum, 
with two compressed reflected feclers; the tongue is short and membranaceous, obtuse and bifid; the caterpillars have sixteen fect, often hairy; and the pupa is pointed at the tip. This section is subdivided as follows :-

a. with the wings expanded.

b. with the wings reversed.

$c$. with the wings deflected.

d. with the wings incumbent.

c. with the wings convolute.

Scction H. Geometra.-The antenne are filiform; the feelers are cylindrical; the tongue is projected, membranaceous, sctaccous, and bifid; the larve have fiom eight to ten fect, six of which are pectoral, two caudal, and sometimes two subcaudal; the pupa have pointed tips. The following are the subdivisions of this section:-

a. the antenne are pectinated.

$b$, the antennac aro setaceous.

c. the wings are forked and connivent.

Section III. Noctun.- The antenna are setilecous; the feclers are compressed and latiry, with the tip eylindrieal and naked; the tongue is projecting, homy, setaceous, and bifid; the larva has sixteen feet; the pupa is pointed at the tip. The following are the subdivisions of this section :-

a. with the wings expanded.

b. with the wings flat and ineumbent, and the thorax smooth. 
c. with the wings flat and incumbent, and the thorax crested.

d. with the wings deflected, and the thorax smooth.

$P$ with the wings deflected, and the thorax crested.

Section IV. IYrt.,A.-The antenne are setaceous; the feelers are projecting, compressed, dilated in the middle; the lips are projecting and active.

Section V. Hriralus.-The antenne are moniliform; two feelers, which are reflected and hairy, between which is the rudiment of a bifid tongue; the larva have ten fect; they feed on the roots of plants; the pupe are folliculate, cylindrical, and pointed at the tip.

Section VI. Cossus.-The antenna are short and filiform, with two very short cylindrical, deHected feelers; without a spiral tongue.

Section VII. Pyraris.-The antenne are filiform, with two feelers equal, ahmost naked, cylindrical at the base; the middle dilated into an oval, and subulate at the tip; tongue projecting, setaceous, and bifid; the wings are very obtuse, and slightly curved at the exterior margin; the caterpillars have sixtcon feet, and make nests in the leares on which they feed, and are of that kind known by the name of Leaf-rolling Caterpillars.

Section VIII. Tinea. - The antenne are setaceous, with four unequal feclcrs; the larva are found 
in houses, among linens, and woollen cloths and furniture, in which they eat holes, and to which they are very destructive.

Section IX. Alverta.-The antenna are setaceous, with the feelers divided to the middle, the inner division very acute.

Section X. P'Tenorionus, - With two linear naked feclers; the tongue is exserted, membranaceous, and bifid: the wings are fan-shaped, divided down to the hase, and generally sublivided as far as the middle: the larva have sixteen ovate, hairy feet; the pupe are naked, and subulate at the tip.

Modem naturalists have taken a different vicw of the arrangements of payilionaceous insects, and formed them into various orders and new genera ; these we shall describe at length in our third volume. 


\section{THE PINK UNDlR-WING MOTH.}

\section{Phatana Jacobea.}

PLATE LXXIII,

Phalena Jacolect, Limn, Syst. Nat, ii. p. 239.-Tuton's Limn', iii. p. 220.-Donotan's Brit. Lus. ii. pl. 45. IIarris's Aurelian, pl, 11.

The upper wings are of a brownish hlack, with a transverse pink lrand, and two orate spots on each; the under wings are pink, with fmllriated margins; the body is reduish brown, the eyes white, and the antenne taper from their insertion to the tips.

The caterpillar is of a rich golden yellow, amulated with leeg black; the segments are furnished with a little tuft of long hairs between each, which are much longer on the head; it is found in the latter end of July, feeding on the ragwort. It clianges into a chrysalis in the beginning of $\Lambda$ ugust, in which state it lies on the surface of the earth during the winter; and it emerges the perfect moth in May following, towards the latter end of the month. 'This is one of the prettiest of our British moths. 


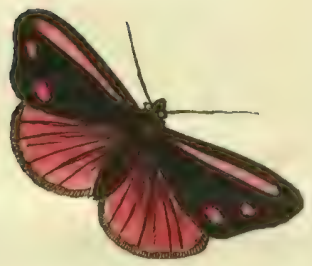

78.

PINK UNDFI-WING MOTH.

Phalena Sacolec, BRitaIX. 




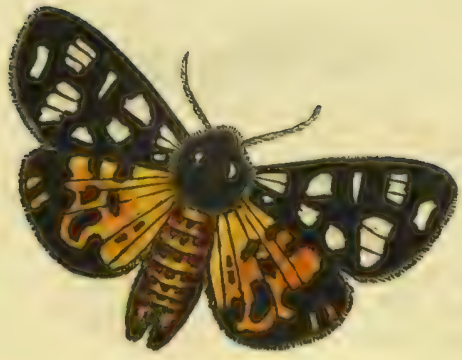

74.

THK CRKAN SPOTTED TIERR MOTH,

Phalana Villica.—Bnitain. 


\section{TIIE CREAM-SPOTTED TIGER MOTIS.}

\section{Phalana Villica.}

PLATE LXXIV.

Phalæna Villica, Linn. Syst. Nat. ii. p. 320.-Turton's I.inné, iii. p. 222.-Donovan's Brit. Ins, ii. pl. il.Harris's Aurelian, pl. 4.

The upper wings are black, with from eight to nine large irregularly shtiped cream coloured spots ; the under wings and body are of a rich yellow orange, or approaching to golden yellow, rarinusly clouded with large black irregular patehes; the body has a row of equal black spots down the middle; the thorax is black, with two cream coloured spots on the back; it is fringed all round, as are also the wings.

The caterpillars of this moth are black and foxy, or hairy, with pink legs; they feed on chickweed, which is their favourite food, but they will also eat the leaves of the currant, white thom, nettle, grass, de., if the former cannot be readily procured. They have attained their full size by the latter end of $\Lambda$ pril, when they change into a chrysalis, and, towards the end of May, they appear in the winged state.

'I'he Cream-Spotted Tiger Moth is by no means so) fiendently to be met with as the Great Tiger Noth, 
(I'lalerna caja,) but, in the happy combination of its colours, it surpasses both it and every other British species of that tribe which are trivially named Tiger Moths. It is most frequently to he found on banks which face the rising sun.

The Linglish specimens of this insect rarely exeed two inches and an eighth from the tip of one wing to that of the other. The one from which our figure is taken was a German speeimen, and measures two inches and a half. 



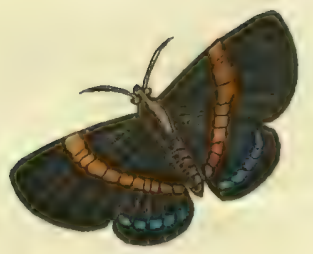

$$
75 .
$$

THE WANDEMLNG NOTH.

Phalana Errote,-Suranam. 


\title{
TIE WANDERING MOTII.
}

\author{
I'halana Errotu. \\ PLATE LXXV. \\ 1'halaxa Errota,
}

Tre wings of this curious insect are black, with a sesquitertious brownish orange band running from the centre anterior margins of the superior wings across both upper and under ones, and a pale blue nacular transverse land about the middle of the inferior wings; the body is reddish brown, and the antenna short and smooth.

'The IVandering Moth inhabits Surinam, where, arcording to Madam Merian, it is rare. 


\section{THW FOOTMAN MOTII. \\ Phalena Grammica.-Femąr.}

PLATE LXXVI.

Phalwna Grammica, Linn. Syst. Nat. ii. p. 830.-Turton's Linné, iii. p. 221._Donovan's Brit. Ins:_.YHcrian, Ius. Europ, i. pl. 5.

Uners wings of a fine golden yellow, transversely streaked with black; the under wings and body of a very bright golden yellow, with a black terminal band; the whole are fringed.

This elegant species is introduced among the British lepidoptera, upon the most satisfactory authority, namely, that of Mr Donoran, who found a living specimen of it on the island of Anglesen, in the inonth of September, under the shade of a little cluster of stones and bushes, near Manachty, the northern extremity of the island, and at no great distance from the road to Grogridy.

It had not before been noticed as a British insect, till discovered by this indefatigable author, to whose industry the British Fauna owes many of its novelties. It is not unfrequent in Germany, and several other parts of Europe. 


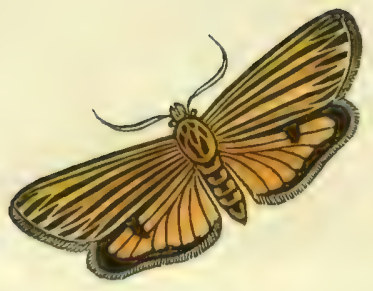

76.

THK FUUTMAN MOTH.

Phatena Cirammica, Female, Baran. 

It is rarely to be met with in the larva state, and feeds either on the plain-tree or ash. The larra is brown, with a white dorsal line, and rufous legs: the pupa is rust coloured. 


\title{
THF IANTHONA MOTH.
}

\section{Phalena Panthone.}

\author{
PLATE LXXVII.
}

Phalenn Prnthona.

'THe wings are black, with a white macular band running round their posterior and anal margins. The body is slender, of a beautiful sky blue, as arc also the head and antenno; the cyes are bright scarlet.

This insect inhabits China, but we know nothing of its history. 


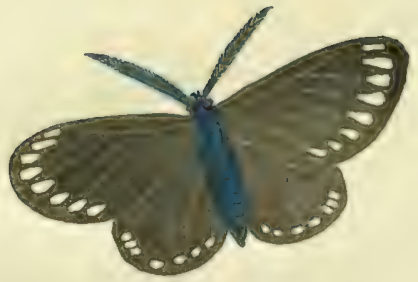

7\%.

THE PANTIONA MUTH.

l'halocua l'anthona.CHesa. 



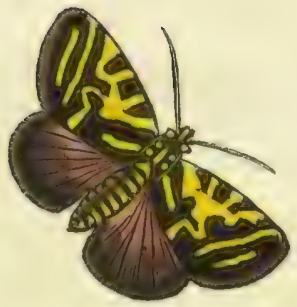

78

THF MARGATE BFAUTY MOTH,

rhalene S'ulphuralis._Bartas. 
TIE M.ARGATE BEAUTY MOTH.

Phalana Sulphuralis.

PLATE EXXVIH.

Phalena Sul plumalis, Limn. Syst. Nat, ii. p. 381.-Donoran's Brit. Ins. No. 333, pl. 339._Bombỵx Lugubsis, Fabr. Ent. Syst. ii. p. 1, 467.

The upper wings are of a bright yellow, variously clouded with black; the under wings are of a purple brown; the whole fringed with a broad border of the same colour. The thorax and body agrecing in colour with the upper wings, spotted and barred with deep black.

This is searce as a British moth. It is said to have been first discovered at Margate, and from this circumstance was afterwards known amongst English collectors by the name of the Margate Beauty. Another insect, by no means similar, has, however, received the same name, having likewise been furst met with at Margate.

The size of this moth, from tip to tip, is about five eighths, or about one third the size of our figure. 
TIE MATRONULA MOTH.

Phalcena Matronula.

PLATE LXXIX.

Phals.na MIatronula, Limn. Syst. Nut. ii. p. 335.-Shau's Naturalists" Miscellany, h1. 932.-Werian's Insects of Furope, p. 53, No. 5.

Tile supcrior wings of the Matronula Moth are of a rich fawn coloured brown, with two abbreviated rich golden yellow bands, and three large spots on each wing,-the whole forming a kind of nacular transverse band on cach wing; the inferior wings are ochre yellow, with three large clouds of black on each; the head and lack are black, the latter with a golden band on each side, and a spear-shaped mark of the same colour under the heat; on the back is a horseshoe-shaped hame of rich crimson; the eyes are golden-yellow, and the antenne hlack, long, and smooth; the abdomen is luight scirlet, spotted with black; at the upper margin of each of the amnulations are small spots of the same colour on cach side.

This moth is a native of various parts of Germany, where its larva is sail to fecd on the leaves of the common mugwort, the Aitcmisia vulgaris of Linnเets. 


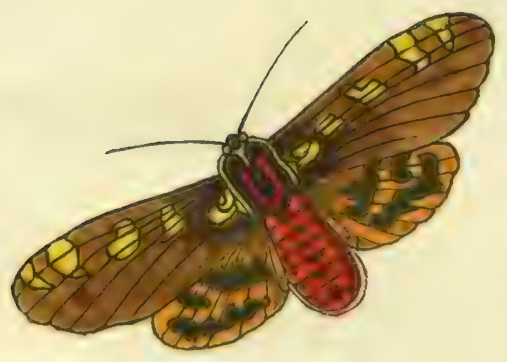

79.

THP MATUONUI, MOTH.

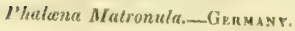






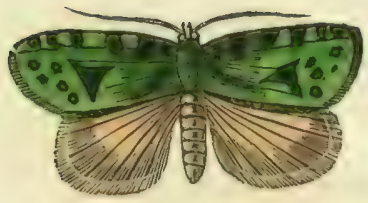

So.

THF LAT TH (KF D MOIH.

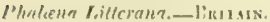


THE LEITEREI, MOTI.

Phalnena Litterana.

PLATE LXXX.

Platann Litterana, Limn. Syst. Nut. ii. p. U76.-F'ub, lint, Syst. iii. p. 2._Donovan's Brit. Ins. pl. 355, fig. 2.

TIIE upper wings are rhombic, and of a leek green colour, spotted and patched with black; the under wings are of a pale fitwn colour; the thorax is of the same colour as the upper wings, and the abdomen like those of the under wings; the antenne taper from the base to the tips. The wings are all fringed round.

This rare and beautiful little insect is a native of Britain, and is not quite six-eighths of an inch in brearth. It is not unlike the Phalæna Squamma. 


\section{THE CURRANT MOTII.}

\section{Phalana Grossulariata.}

\section{PLATE IXXXI.}

1'haleena Grossulawiuta, Limn. Syst. Nat. ii. p. 867.Donovan's Brit. Insects, pl. 4.

T'ue wings of this very common species are white, covered with a great variety of black spots and fillets; on the upper wings is a sesquitertious bright urange band, bounded on its imner edge by an interrupted band of black, and on its outer edge by a row of equidistant black spots; the body is of the same colour; the segments have cach a black spot ; the head and eyes are black ; the antenna are long, slender, and tapering.

The caterpillar is white, with black spots on the hack; the belly is yellow; and at the insertion of the anmulations is a tuft of very fine hairs ; it foeds in gooseberry and currant bushes, and generally emerges from the egg in Nay. The caterpillar, previous to its change into the pupa state, spins for itself a web of a very slight and delicate texture, by which it is suspended horizontally against the branches of trees. The pupa is black, with a yellow fillet at the annulations, and three spots of the same 


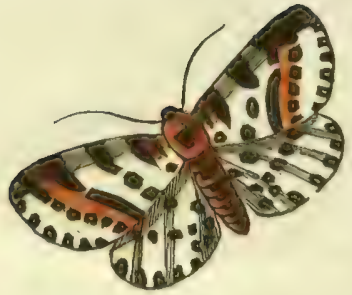

81.

THE CUHAANT MOTI.

I'hulene Grossulariala.-B BITAIN. 

colour on the back; and is transformed into the perfect, or imago state, in July.

There are fow creatures whose ravages are nore severely felt than the larva of this insect, and every means possible should be used to eradicate them; for, if once they find a lodgenent, it is no casy matter to get rid of them.

A friend of mine in this city, who has a good garden, and is celebrated for his humanity, had a range of the finest wall-currants which I ever saw totally destroyed by these insects. $\mathrm{He}$ would not. allow them to be killed when they first made their appearance, and the third year afterwards they became so numerous, as to eat up every leaf on the lushes; and, at last, he was forced to root them out to get rid of these pests, which his ill-judged humanity had harhoured and encouraged. 
THE CHIMAON UNDER-WTA MOTH

\section{Phalona Sponsa.}

\section{PLATE LXXXII.}

Phaluna Sponsa, Limn, Syst. Nut. ii. p. 841.-Turton's Linné, iii. 1. 293._Donotuie's Brit. Insects, pl. 324.

THE antenne are like threads; the tongue spiral ; the thorax is crested; and the alidomen fumished with tufts of hair, one on each ammulation on the belly. The body is fawn coloured, loruwn above, and gray beneath. The uper wings are gray, clouded with brown, and covered with zigzag lines and strie, and two ocellated spots of orange; under wings, of a rich crimson colour, each with a transrerse cloud of deep black, and a broad margin of lilack, fringed with white; all the margins are pretty deeply indented. The caterpillar is clouded with buff, brown, and gray; it feeds on the willow, and grows to about two inches and a half in length ; and it is difficult to distinguish it from the bark. 'They are full fed about the beginning of July, when they change into the chrysalis state; it is gray, with at tinge of red. The moth bursts from the ehrysalis August, and flies in the day-time. 


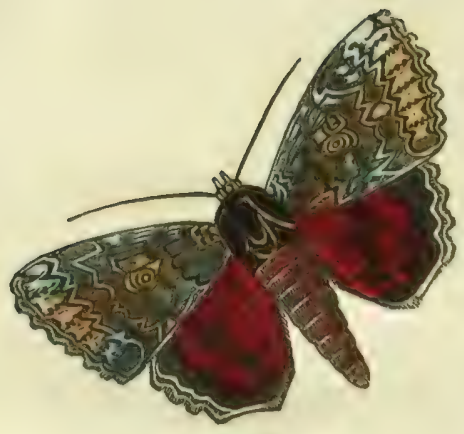

82.

THE CRIMSON UNDER-WING MOTIT.

Phalana Sponsa,-Britain. 



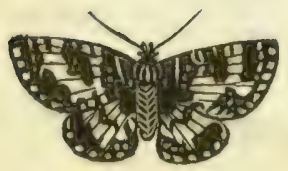

$8: 3$.

THE $\triangle R G F N T$ AND SARE MOTH, J'halona Mastata, - Hritaimi 


\section{TIE ARGENT AND SABLE MOTII.}

\section{Phalena IIastata,}

PLATE LXXXII.

Whalena Ifustata, Limn. Syst. $\boldsymbol{N}^{r}$ at. ii. p. 870.-Clcrk Plial. i. liv. 9.-Donoeran's Brit. Inscets, pl. 129.

Tune wings of this moth are white, beatifully marked and spotted with black; the thorax is black, with three longitudinal white spots on the back; the abdomen white, striped with blaek.

The Argent and Sable Moth is a very searee British insect in the fly state, though its young eaterpillars are by no means uncommon in several parts of Kent; especially in the narrow lanes in Darentwood, Dartford, in $\Lambda$ pril, or early in the month of May. It is, however, very difficult to lreed them, as they generally dic in the pupa state, or before they cast their skins, when caterpillars. Donovan mentions them in the summer of 1795: he took several specimens of the caterpillar and bred them, and yet he could only procure the transformation of one moth, and that so crippled, as merely to enable him to aseertain the species.

The small caterpillars are of a dark purplish colour; when nearly full fed, they have a yellow 
under side, marked with black. Before they change to the pupa state, they become almost brown.

They continue in the pupa condition for a montl. and the moth is transformed in Junc. The food ot the caterpillar is white thorn. 



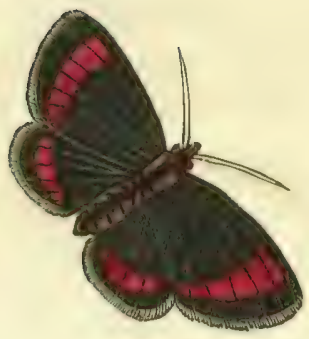

84.

THE FIIFNDLY MOTH.

P'haliena Amica.-Africa. 


\section{TIE FRINDLY MOTH.}

\section{Phalana Amica.}

\section{PLATF LXXXIV.}

\section{Phalenn Amica, Trurton's Linné.}

T'ın wings are black, with an articulated erimson band on each, a little way from the margins, which are fringed; the body is of a chestnut brown; the cyes crimson; antemie, long and smooth; and with a transverse crimson fillet across the back, immediately under the head.

This rare moth is a native of $A$ frica. 


\section{THE IIEIBE MOTH.}

Phalcena IIebe.

PLATE LXXXY.

Mtatiana Ilebe, Linn. Syst. Nat. ii. p. 820.-Turton's Iinné, iii. p. 222.-Frisch. vii. pl. 7. fig. 9.-moes. iv. pl. 27, fig. I, 2.

'Trге upper wings are black, with transverse bands of white, which are edged with pale crean colour; the under wings of rich crimson, with curiously shaped clouds of black, which are edged with golden yellow ; the head and bolly are black; below the head is a transicrse spot of bright crimson; the antennie are long, black, and setaceous, decreasing from the base to the tips; on each side of the body is a row of six large, circular crimson spots, with a line of the same colour passing through them. The abdomen, crimson.

This highly beautiful species is figured of the matural size; it is a mative of Germany, and some other parts of continental Euroje, but has not hitherto been found in Britain. The larva, or caterpillar, is solitary; moderutely large; very hairy ; and of at hlackisl, or dusky colour, rufous beneath, with the three last segmonts rust coloured. The chrysalis is of a blackish cast. 


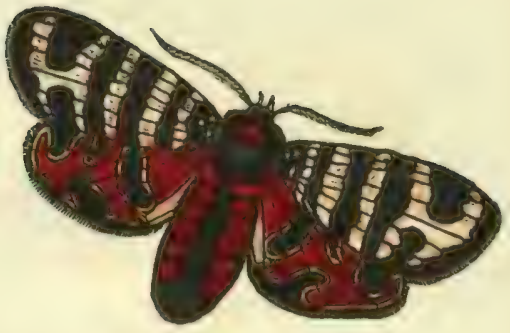

85.

THT HEBE MOTH.

Phalana IIele.,Gramany. 




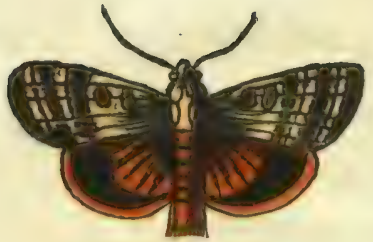

86.

TIIT BROAD BORDFRED YPLLOW UNDFR-WINO NOTII. Phalana Fimbria.-Britain. 
THE BROAD BORDERED YELIOW UNDER-WING MOTII.

Phalena Fimbria.

PLATE LXXXVI,

Phalæna Fimbria, Turton's Linné, iii. p. 296.-linn, Syst. Nat, ii, p. 842._Fab. Ent. Syst. iij, p. '2.

The upper wings are of a high toned buff colour, marked with olseure bands, or streaks; the under wings are reddish orange, with a broad bar of black towards their anal margins, and a border of orange; the thorax, same colour as the upper wings; and the abdomen corresponds with those of the under wings; it has a transverse tail ; the antenna taper from the lase to the tips, where they are very slender.

'This rare British insect is distinguished from two very common species that are allied to it, hy the broad stripe of black on the umber wings, as its trivial name inplies. In the larva state, it is one of that kind which collectors call under-ground feeders; subsisting chictly on the roots of grass, and never appearing above ground till the evening, for which reason it is rarely taken liy naturalists. It is of a dull brown colour, having a double stripe of white extending from its head to its tail ; and each segnent 
130 THE YELLOW UNDFR-WING MOTII.

is furnished with a brown oblique spot. Before chamging into the chrysalis state, it gathers around itself a cluster of small leaves and bits of grass, where it remains till its transformation. The pupe is of a brownish black.

The moth is very delicate in its appearance, and it assumes the imago state in May. Fabricius says it inhabits Germany. 



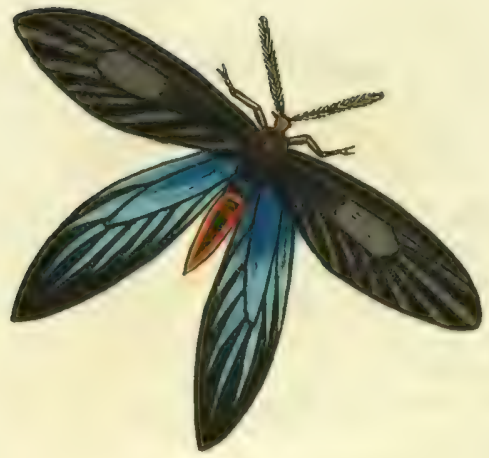

87.

THF. HHODOPE MOTH.

P'halana Rhodope,-Сика. 
THE RIODOPE MOTI.

\author{
Phalcena Rhodope.
}

PLATE LXXXVII.

Phatana Rholope, Fab. Sp. In. ii. p. 163.-C'ramer, Ins. pl. 30 , fig. $\mathrm{e}$.

'Tre upper wings are black ; and the under wings of a bright bluc, radiated with black; the body is black, with a large spot of blue towards its centre; the lower part of the segments of the abdomen are of a bright orange, with square and lanceolate spots on the lower part of the back; the head is orange, and the antennæe long and sctaccous.

This remarkable and singularly shaped insect is am inhabitant of China, and is represented on the plate of its natural size. 


\title{
THE BRIGHT MOTH.
}

\author{
Phalena Flavia. \\ PLATE LXXXYII. \\ Phalsena Flavia, Turlon's Linné.
}

Tre upper wings are of a rich eream yellow, with large irregular patches of deep black; the lower wings are of a fme brownish orange, gradually hecoming lighter as they aprroach their junction with the bedy, with three large black patches towards the anal extrenity of each; all the extcrior and posterior margins are fringed ; the antennie are rather short and tajering; the hody is of a deep erimson, as well as the eyes; the back with a large (ircular black spot, and a narrow longitudinal hand along the sogments; the tail is deep black.

This very fine moth is a native of the frigid confines of the north, being found chiefly in Silocia, a climate where insect life is extremely limited, owing to the shortness of summer. 


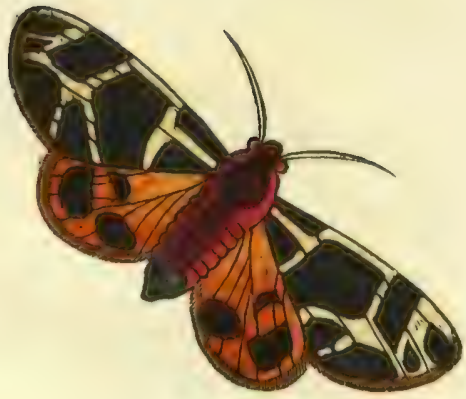

88.

THF BNIGIT MOTH.

Platcona Flavia.-Siarurs. 




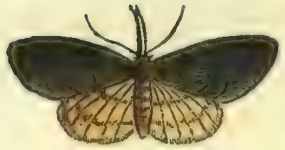

89.

THK SNOUT MOIH,

Thakena Rostollum-BHтаIN. 


\section{THE SNOUT MOTI.}

\section{Phatcena Rostellum.}

PLATE LXXX1X.

The snout Moth, IIarris's Aurelian, p. 86, pl. 43, fi.. 6.Ilypena nolocidalis, Ochsenheimer, Rennie's ('onspetus of Butterfies, page 145.

Tue superior wings of this curious moth are of a deep brown black, with three darker ones crossing them. The lower wings are of a yellow fawn colour, as also the hody ; the former witl two lines crossing each. One of the most peculiar features of this moth is the length of its palpi, which project in the form of a snout. The antenne are like threads.

The caterpiliar of the Snout Moth is of a rich tawny ; it feeds upon oaks, and is to be found in Oetober, by beating the trees. They spin themselves a nest in the leaves, being one of the species linown by the name of leaf-rolling caterpillars. They change into the chrysalis form in the end of Octuber, ans continue in this condition till the following Jume, when they are transformed into the imago, or perfect moth, which expands about an inch and a half. 
THE SMALL TIGDR MO'TH.

Phalcena Plantagines.

ISLATF XC.

Phislema Plant:ginev, Linn. Syst. Nut, ii. p. 820.-Wrilkes's Pap. 24, pl. 3, A. 5. Donowan's Brit. Ins. pl. 134.

TrE upper wings are of a reddish cream colour, in some individuals, and of a rich golden yellow in others, clouded with black; the under wings are loright fawn colour, with numerous large variously shaped clouds or patches of black; the thorax and abdomen are crimson, barred with black; having a large black line down the centre of the back; the antenna are black, and tapering from the base to the tips.

The catcrpillar of this species is black, the upper half of it being corered with rather short reddish brown hairs, and the under half with long black recumbent hairs; it feeds on nettles, chickweed, plantain, grass, \&c. It very much resembles that of the Large Tiger Moth, (I'halena caja,) except in size; it changes into a chrysalis about the middle of April, and appears in the winged state the latter end of May. The chrysalis is bluish black. 


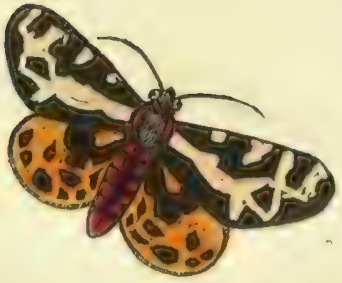

90.

THF SMALL TIGET MOTH. LFMALE. Phalana Plantaginis.-Вuтм. 
Ihis is rather a scarce British lepidoptera, being infinitely more rare than the Ruby Tiger Moth, (Phalena fuliginosa,) and the Great Tiger Moth.

A variety of this species, with crimson under wings, is found in the East Indies and in America. The under wings of the female, in the European specimens, are much redder than those of the male. 


\section{6}

TIIE BLACK AND CREAII SPOTTED MOTH.

\section{Phalena Atralis.}

\section{PL.ATE. XCI.}

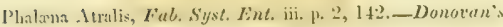
Brit. Ins. pl. 266, fig. \&.

Tue wings are black, with two crean coloured spots on each.

size of the insect, five-eighths of an inch, with extended wings.

It is said to be found in Germany, and is very rave as a British species, but has been taken on Lipping Forest. 


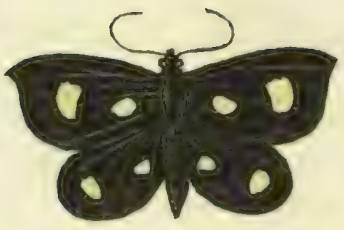

91.

THE BLACK AND CIVAM STOTTED MOTH. Phalona Airulis.-Buтsin. 




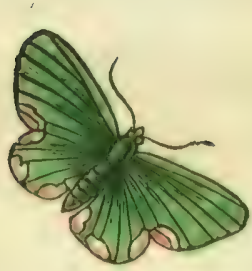

92.

TUF MAID OF IONOUR NOTH.

Phalena Difaria.-Bratain. 
THE MAID OF HONOUR MOTII.

\section{Phalena Dilaria.}

PLATE XCII.

Phaliena ditaria, Fab. Ent. Syst. iii. p. 2.-Wein. Vere. 97. 6.-Donovan's Brit. Ins. 1.-IIarris's Cat. 31. 218. pl. 202.-Cleorn Cajularia, Stcphens.-IRennie's Conspectus of Butterfies, p. 110.

THe wings of this beautiful insect are one inch one-twelfth, to one-fourth; are bright green, with white spots, having rose-coloured elouds towards their extremities; the fringes are white, spotted with brown; the thorax and abdomen are also of the same colour. The antenna taper from the base. The caterpillar is gray, and feeds upon the oak.

This appears to be a very local species. It has been found for many years past, in the month of June, near the Oak of Honour, in the neighbourhood of Packham, and likewise in Kent and Surrey.

It is also a continental species, but seems to be very rare, as Fabricius refers to only one author for it. He says that it feeds on the oak. 


\section{THE RUBY TIGER MOTII.}

Phalena Fiuliginosa.

PLATE XCIII.

Phalena fuliginosa, Linn. Syst. Nat. ii. p. 836.-Harris's Aurelian, pl. 12.-Wilkes's Pap. iii, a 14.-Donoran's B3rit. Ins. pl. 80. - Phragmatobia fuliginosa, Stcphens.Rennie's Conspectus of Butterfies, p. 43.

Tine superior wings and thorax of this pretty little insect are of a rich reddish brown, with two black spots in the centre; the inferior wings are of $a$ deep rose colour, but not very bright, with a row of large black marks; they are five-sixths to one inch and a half; towards the lower margin the abdomen is rose colour, with a black spot on the centre of each segment behind, and a chain of little black dots down each side.

The upper wings of some specimens have a black spot on each, which varies very much in situation and size; in some it occupies about half the space of the wings, while in others it is entirely wanting.

The caterpillar is of a rich fawn colour, or rusty red, completely covered with long hairs, with a black head, and is large in proportion to the size of the Moth; the fore-legs are also black. The leaves 


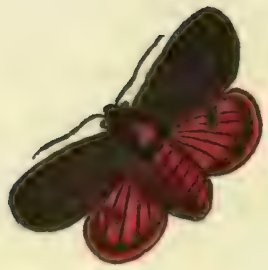

(93.

TIF RUBY TIGE MOIII.

Pha'dene Fuliginosa, - Bвытат. 

of alder or birch, the turnip, mustard, plantain, and ragwort, with many other vegetables, are noticed by different authors, as being proper food for the Ruby Tiger Moth in the larva state; but its most common food is ragwort and groundsel. The caterpillars are small in the month of May; in June they pass to the pupa condition, and early in July appear in tho winged state. The pupa is black, and cnveloped in a follicle.

In a forward scason, the time of their appearance in different states may vary considerably, especially as some have tivo, or even three broods in one sum$\mathrm{mcr}$. This insect is a native of Britain, and is usually little more than an inch in breadth, although in this particular it is subject to vary. It is found in Durham, Yorkshirc, Hertfordshire, Kent, and Surrey, and near 1)ublin in Ireland. 
TIIE SMALL MIGPIE MOTH.

P'halena Urticata.

PLATE XCIV.

Phalan Crtienta, Linn. Syst. Nut. ii. p. B73.-T Turton's Linní, iii. p. 269.-Donoven's Brit. Ins. jil. 349, fig. "?. -Botys Urticata, Latreille.

The head, throat, and abdomen are rich yellow, as is that part of the superior wings near the shoulder; all the wings are white, finely spotted with black.

The larva conceals itself in a kind of cylinder, formed by rolling up the edges of nettle leaves, on which it feeds. It is whitish, with a dark dorsal line; head black, and two spots of the same colour on the segment next the head. It continues in this way till the cold weather sets in, when it changes to a red colour, and spins a buff coloured case, through which it may be distinctly seen; in about a month it changes to a yellow colour. In the following May it assumes the chrysalis state, and transforms in June.

This insect is found abundantly near London. 


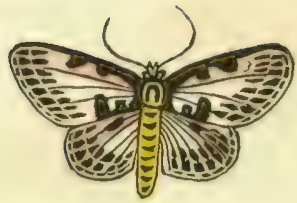

94.

TUE. SMALL MAGPIE MOTIS.

Phalona Urticata.-Bartals. 




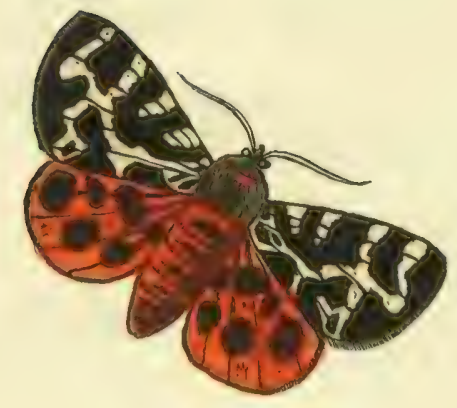

95.

THE GREAT TIGFR MOTH.

Phalena Caja.-Britain. 


\section{THE GREAT TIGER MOTH.}

\section{Phalana Caja.}

PLATE XCV.

Plakisna Cijja, Linn. Syst. Nat, ii. p, 819,_Turton's Linne, iii. p. 223,-Donovan's Brit. Ins. i. pl. 15, -Aretiil Cijja, Stephens.-Rennic's Conspectus of Bulterfics, p. 42.

Tris superior wings of the male are two inches two-thirds to eleven-twelfths; and those of the fenale two inches and three quarters to three inches; they are of a cream colour, with large irregularly shaped black patches, which vary considerably, both in shape and size, and frequently two are united to form one. The inferior wings, and annulations of the body, are of a rich orange, which also admit of equal varicty; the spots near the thorax are often united, and the small black stripes on the back are fewer in some specinens than on others; the back and thorax are of a raw umber brown, thickly beset with fine hairs and bristles; under the head is a semilunar stripe of a fine pale crimson.

The caterpillar is solitary; of a high coloured chestnut, sometimes black; thickly covered with long hairs of nearly the same colum; cach of the 
segments are provided with three elevated, bluish warts; these are situated on the sides. It feeds on lettuces, chickweek, and nettles; and when apprehensive of danger, rolls itself up like a hedgehog. It changes into the chrysalis state in May; and the latter end of June, or the beginning of July, is transformed into the perfect moth. The pupa is black, or brown, and cnclosed in a case, or follicle.

This moth is to be found abundantly in most places of Great Britain, and may be seen flitting about, where nettles are growing, in the dusk. It makes its appearance about the end of July. 



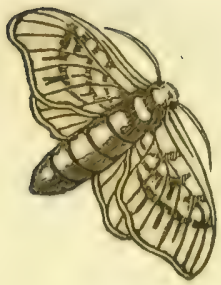

96.

THE SILKWORM MоTH.

I'halena Mori.Cuns. 


\section{TIE SILKWORM MOTII.}

Phalcena Mori.

PLATE XCVI.

l'hilena Mori, Linn. Syst. Nat. ii, p. 817.-Turtmin's Linné, iii. p. 204.-IItrris's Aureliun, pl. 13, fig̣. r. 1.Albin, pl. 12, fig. 16.

Tin Silkworm Moth is of a pale buff colour, having two faint lines crossing the wings, which are slightly bent, or curved at their apices. The figure at Plate XCVI, is about the size of nature.

Pullein, a popular writer, has justly observed, "There is scarcely any thing among the various wonders which the animal creation affords, more admirable thau the variety of changes which the Silkworm undergoes; but the curious texture of the silken covering with which it surrounds itself when it arrives at the perfection of its animal life, vastly. surpasses what is made by other animals of this class. All the caterpillar kind do, indeed, undergo changes like those of the Silkworm, and the beauty of many of them in their butterfly state greatly exeeds it; but the covering which they put on before this change into a fly state, is poor and mean when compared to 
that golden tissue in which the Silkworm wraps itself. They indeed come forth in a variety of colours, their wings bedropped with gold and scarlet, yet are they but the beings of a summer's day; both their life and beauty quickly ranish, and they leave no remembrance after them; but the Silkworm leaves behind 'it such beautiful, such beneficial monuments, as at once record both the wisdom of their Creator, and His bounty to man.

The eggs of the Silkworm are about the size of a grain of mustard-seed, of an ovate shape, and depressed in the centre; they are at first of a yellowish colour, but, in three or four days, acquire a bluish east; they are laid in irregular patches, on the leaves of the mulberry. In this country, the eaterpillar is produced in May. When first hatched, it alyears like a small black worm, not a quarter of an inch in length: it almost immediately moves about in scarch of food, at which time it is more vivacious than at any other period, as it is a dull, lifeless animal when full grown, and seldom moves heyond three or four feet during its larva state: hence the ease with which it is managed when mltivated for its silk.

It has sixtecn legs, set in pairs; six in front, which are covered with a shell, or scale, are placed under each of the three first annulations next the head, and camnot he altered in their position. The other ten feet are termed holders; these are membrana- 
cenus, flexible, and provided with small hooks, which assist the animal in climbing.

The fullowing is a figure of the caterpillar, about. two-thirds its dimensions when full grown:

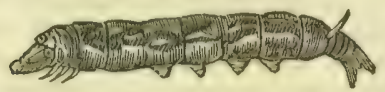

The shell is enclosed in a membranaceous sub. stance, similar in consistence to the first six legs. The mouth is vertical, and the jaws serrated like a saw. The animal is furnished with eighteen breathing holes, nine on each side down the body, at equal distances. On each side of the head, near to the mouth, seven eyes may be discovered by the aid of a lens. The two circular protuberances higher up the head, which look very like eyes, are simply bones of the skull. The spinning apparatus is similar to that described at jage 68 of this volume.

When the worm becomes satiated with eating, it then prepares for its change into the chrysalis condition. The worm now fixes upon an angle, or hollow place, whose dimensions agree with the size of its intended cocoon, and begins its task by spinning thin and irregular threals, which are for the support of its future dwelling. The first day's labour consists in forming a loose structure, of an oval shape, which is termed floss silk, and within this covering, in the three following days, it works tho 
firm and consistent yellow ball ; the labour always, of course, remaining within the sphere of the cone which it is forming.

If at any time the threads intended for the support of the cocoon should be broken, the ball not being properly poised, becomes unsteady, so that the insect is unable perfectly to go forward with its labours. Under these circumstances, the worm pierces a hole in, and altogether abandons the unfinished cocoons, and throws out its remaining threads at random wherever it passes, by which means the silk is wholly lost, and the catcrpillar, finding no place wherein to prepare for its change, dies without having effected it.

At the end of the third or fourth day, the worm generally completes its task, and has formed its cocoon, which, in size and shape, is like that of a pigeon's egg. It is, however, but seldom that it attains so large a size. The following figure represents the cocoon upwards of two-thirds the ustal size, with part of the floss silk removed:

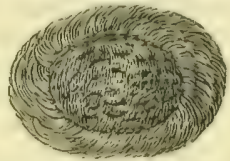

The operation of spinning, and the cmission of so large a quantity of silk, uneompensated by food, 
eauses the worm gradually to contract in bulk; it becomes shrivelled, and the wings of its body approach nearer to each other, and their articulations become more distinctly marked. When the cocoon is completed, the larva rests from its toil, then throws off its caterpillar garb, and changes into the chrysalis state, in which condition it is somewhat like a kidney bean, having a smooth brown skin. The following is a figure of the chrysalis :

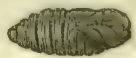

The Silkworm remains in its pupa state for periods depending on the climate or temperature wherein it is placed, varying from fifteen to thirty days; it then throws off its shroud, and appears in the perfect, or imago state. The moth enjoys its liberty but for a very short space of time. Its first object is to seck its mate, after which the female deposits her eggs, and both male and female die in a few days thereafter.

It is certainly curious to reflect, how this animal should enjoy so short an existence in its perfect condition; for by far the longest period of its life is in its caterpillar state. A complete suspension of its animal faculties takes place when it changes to a chrysalis; and when it emerges from this state, the whole business of its life is the continuation of its species. It does not even enjoy the grateful pleasure of food. 
The following represents the female Silkworm Moth, about two-thirds of the size of life, in the act of laying her eggs :

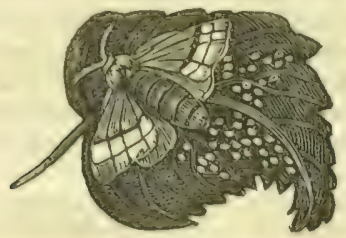

The mumber produect by one fumale is variously stated. Some accounts mention 250, while others reckon 4.00 to 500 as the usual number.

One of the most astonishing circumstances connected with the natural history of Silkworms, is the degree in which their bulk and length are increased, and the rery limited time in which that is accomplished. Count 1)andolo counted and weighed many a hundred thousand egres, and found that, on an average, sixty-cight sound Silkworm's eggs weighed one grain. One ounce, "therefore, comprised 39,168 eggs. But one-twelfth part of this

* This ounec contains 576 grmins; 8.5325 of these gratins "qual seven grains troy. (He ounce avoirlupois is therefore "gual to about 533 of thene gratine, and between onc-twelfth and one-thirtenth ounce avoirdupois equals one of the above Duneres. 
weight evaporates previous to hatching, and the skins in which they are contained are equal to onefifth more. If, therefore, from one ounce composed of 576 grains, 1.8 grains be deducted for evaporation, and 115 for the shells, 4.13 grains will remain equal to the weight of 39,168 young worms ; and according to this computation, 54,526 of the larve, when newly hatched, are required to make up an ounce. After they part with their first skin, 3840 worms are found to be this weight, so that the bulk and weight of the insects have, in a few days, been multiplied more than fourteen times. After the second change, 610 larve weigh an ounce, the weight of the animals being inereased, in the intermediate time, six-fold. In the week passed between the second and third ages, the number of worms required to make up the weight decreases from 610 to 144, their weight being, therefore, more than quadrupled. During the fourth age, a similar rate of increase is maintained; thirty-five worms now weigh an ounce. The fifth age of the catcrpillar comprises nearly a third part of its brief existence, and has been described by an enthusiastic writer on the subject as the happiest period of its life, during which it rapidly increases in size, and prepares and secretes the material which it is about to spin. When the Silkworms are fully grown, and have arrived at that period when they finally reject food, six of them make up the weight of an ounce, 
They have, therefore, since their last change, again added to their weight six-fold. Thus it will be seen that the insect has multiplied its weight more than nine thousand fold.

It is worthy of remark, that, when the moth has assumed its perfect state, it does not think of using its wings like other winged insects, for it never betakes itself to aërial excursions, and seldom moves beyond a few inches from the spot where it was hatched.

It will be readily imagined, that this remarkable insect occupies a place in our volume, not from personal beauty, but from the importance of its labours in a mercantile point of view, and its utility to mankind. 


\section{THE EARLY HISTORY OF SILK.}

Tre period when mankind first discovered that the ball which contains the chrysalis of the Silkworm Moth might be converted into a texture so beautiful, is hidden by the cloud of antiquity. Nor is it possible to trace the progressive steps by which the high state of excellence of the different kinds of manufacture of this substance has been attained. But it seems certain that the invention of converting the silky filaments into various fabrics is due to the Chinese.

If we go back as far as the oldest histories lead us, we find that the Chinese had acquired a degree of excellence in various manufactures, which they have yet hardly improved upon, and equal to what has been attained in the most civilized nations of Europe. This is especially applicable to silk, colours, and sugar. And, like other Eastern nations, they have made no changes in their modes of manufacture, nor in the simple and rude structure of their machinery, 
while other countries have made gigantic strides towards perfection.

The archives of China record the use of silk in that country 2700 years before the Christian era. The Empress See-linng-skee, consort of Hoang-tee, is said to have been the discoverer of the winding of silk from the cocoon, and of converting the silky filaments into a tissue.

So abundant was it in China long before the Christian era, that in provinces of that country, the peasintry, amounting in numbers to millions, were attired in silk dresses.

Silk was manufactured at Kos, an island of the Axchipulago, in very remote ages. It is related by Aristotle, that Pamphila, a noble lady of that island, was inventress of a superior mode of fibricating a tissue from wove silk, which she undid, re-spun, and re-wove, with the assistance of the females of her household. This manufacture was known by the name of Bombykia, from the word Bomlyyx, a silkworm. It certainly was a singular fancy to undo finished fabrics, to apply their threads to a new species of manufacture. But it would appear to have been excellent of its kind; for it is recorded, that the Roman ladies afterwards adopted the process invented by Pamphila.

From the manufacture having emanated from Kos, Pliny formed the notion that the Silkworm Moth was a native of that island, which subsequent history 
contradicts. There remains but little doulst that, whatever fabrics were there wove from raw silk, that it was the produce of Eastern countries, as was the case with stuffs woven at Tyre, Berytus, and Persia. This seems beyond a doubt; for the historians $Z_{0}$ naras and Theophanes say, that before the introduction of Silkworms into Constantinople, in the middle of the sixth century, nobody in that city was aware that silk was the produce of caterpillars.

In the enumeration of the articles mentioned in the embellishment of Solomon's Temple, we are expressly told of fine linen, but no mention whatever is made of silk, which could not fail to have been noticed had it been then in use; nor did it seem to be known even after the rebuilding of the Temple, as it is not recorded amongst its decorations. It, however, is mentioned as an article of trade in Jcrome's translation of the Bible, where it is said to have been sent from Syria to Tyre, 5Ss years before the time of Christ. It must then liave boen a rare article, as the building of the Temple. was completed only sixty-four year's before that period.

Alexander the Great-who, along with his ambitious desires, united much zeal in extending useful arts throughout his dominions, most probably imbibed from his great instructor Aristotle, who prompted him to explore the great field of nature

vol. II. 
-took care to bring with him, after his victories, from Persia, great quantities of manufactured silks.

The description of the Silkworm given by Aristotle, is the most distinct of all handed down to us by the ancient writers: he details minutely the different transformations, but makes no mention of the country of which the insect was a native.

Much discrepancy prevails among the ancients as to the country from whence the Silkwom was brought. Pliny says, that it was on the island of Kos, on the oprnosite side of the Egean Sea, not far from the coast of Attica, where l'amphila and her nymplis made the tissue so much admired; which might be the means of leading them into this error.

It is a remarkahle fact, that many authors, for the long space of nine hundred years after the time of Aristotle, asserted that scricum, or silk, was cither mate from a flecey suhstance growing upon trees, from the coir, or inner bark of trees, or from flowers; all these opinions, no doulbt, arising from the indistinct accounts which they must have heard of Silkworm larve feeding on the leaves of the mulberry-tree, mixed up with accounts which had reached them of flax and cotton being produced from regetable substances. Sume authors, however, as:erted that it was produced from the filaments of a spider or beetle. 
It is true that, in those remote times, before the invention of printing, discoveries found their way from one country to another by slow and uncertain degrees; so much so, that even men of the greatest learning and information were long of becoming acquainted with established facts. It may appear strange that the learned Isidorus, bishop of Hionolis, in Spain, was unacquainted with the history of the Silkworm, although he wrote a century after its introduction into Europe; for we find him copying the account of that animal from Pliny.

Silk was exceedingly seanty in Europe till the reign of Augustus Ciesar, and continued long after to be a costly and rare commodity.

We are informed that, in the reign of Tiberius, Eastern silk was forbidden to be worn by any one but women of rank; and a law was passed, prohiliting the use of it by males. A cheaper material was invented for people of inferior rank, made of a mixture of silk, with some other more common substance. This species of eloth was called sub-sericum, and became a favouritc costume with both sexes. As Rome improved in wealth, and luxury followed in its train, the demand for silk became so excessive, that it reached a very high price; so much so, that Marc Antony sent ambassadors to Clima to open a more direct commercial treaty with that country, to supply the demand, and reduce the price of the article. This embassy tumed out like most others 
to that jealous people, without attaining the end in view ; so that, for several centuries, Persia became the medium of communication between China and Rome.

In the third century, the profligate Heliogabalus had an upper garment made entirely of silk. And, in the end of that century, the Emperor Aurelian, who was famous for his economy and prudenec, refused the entreaties of his empress, who was desirous of possessing a robe of silk, alleging, as an excuse, that it could only be obtained for it weight in gold.

Persia continued long to reap the benefit of the commerce of silk, which, for the two sueceeding centuries, continued in ligh demand by the luxurious Romans.

The Romans having commenced hostilities against the I'ersians, in the reign of the Emperor Justinian, that monarch tried to procure for his subjects Chinese Ituxuries, through the medium of Elasbaan, King of Axuma, and of Homerites, govemor of Arabia Felix. But these princes wanted enterprise to cnable them properly to fulfil their commercial engagements, which caused the price of silk to rise so high in Constantinople, that few could afford to purchase so costly an article. In this state of things, the Phomicians were anxious to continue their supplies of silken fabrics, but tho impolitic rapacity of the Emperor Justinian nearly ruined the traffic, by im- 
posing high duties on the article, and by the still more arbitrary decree of regulating the price at which the merchants were to sell the commodity. By these measures the price was fixed at a sum equal to L.4 : 15 : 9 English money, or estimated at its weight in gold for the pound avoirdupois, which is much beyond its value at the present time. The rigid manner in which this duty was exacted, com pletely ruined the silk merchants at Constantinople, and what the Emperor intended as an addition to his revenue, turned out very much the reverse.

At this critical period for the silk trade of the Romans, an unexpected circumstance brought about a new era. Cosmus tells us that there were several Christian churches established in various parts of India, and that two monks, employed as missionaries from some of these, found access to the country of the Seres, or China. There, amidst their pious occupations, they viewed with a curious cyc the common dress of the Chinese, the manufactures of silk, and the myriads of Silkworms, whose education, cither on trees or in houses, had once been considered the labour of queens. They soon discovered that it was impracticable to transplant the short-lived insect, but that in the cggs a numerous progeny might be preserved. ${ }^{*}$ They studied deeply the process of the different manufactures, and the habits

"Robertson's Disquisition on the Commerce of Indiat. 
of the animal. On their return, they did not communicate their information to their own countrymen, but bent their way to Constantinople, where they made known to the Emperor Justinian the habits and economy of this curious insect, and developed the Chinese system of making the various fabrics.

At that period they were in entire ignorance from what it was produced; some, however, supposed it was the intestines of a spider-like insect, furnished with eight legs, which was for four years fed upon a paste, and afterwards on the leaves of a kind of green willow, till it burst from orer feeding." l'liny says, silk was the produce of a worm which formed nests of clay, and collected wax. $\Lambda^{\prime} \Lambda$ nd $\Lambda$ ristotle, approaching nearer the truth, says it is umwound from the pupa of a caterpillar with horns. Although he does not expressly say the purn, yot it may he inferred; but it could not be the common Silkworm, (I'haleme mori,) which he meant, as he mentions two characters irreconcilable with it, namely, that of laving homs, and being of a large size.

Stimulated by offers of a great reward, these monks retraced their steps to China, where they contrivert to possess themselves of a quantity of the eggs of the Silkworn Moth, which they concealed in a hollow cane, and brought safely to Constantinople,

* Pausanias, vi. 80. + Hisl, Nat. i. 11. cap, 22. 
in the year 552. These eggrs were hatched in due season, by the aid of manure, and the larve fed on mulberry leaves. The eaterpillars duly commeneed the operations of spimning their cocoons, and, under the superintendenee of the monks, successfully bred, and multiplied to a great extent. $\Lambda$ fterwards, these monks instructed the Romans in the whole mystery of this propagation, and the methods employed lyy the Chinese in manufacturing falorics from the exquisitely fine filaments spun by the little caterpillars."

From the caneful of eggs, thus surreptitiously acquired, have sjurung all the Silkworms which are now to be found in almost every country of W ustern Asia and the South of Europe. These are daily multiplying, and up to the present time, an immensely increased demand for silk has been felt all over the civilized giolse; and an immoral act, which was prompted by the avarice of one man, has proved a blessing to countless thousands, by affording them employment, and a suitable reward for their industry.

The manufacture of silk at Rome was for a considerable time conducted under the care of the treasurer of the rapacious Justinian, who had secret places for carrying on the monopoly; and the monks instructed weavers, which the Emperor brought from Berytus and Tyre, in the Chinese method of making

- Paocopius, de Belli Gathico, lib. iv. c. 1i. 
fabrics. Sills of the imperial manufacture sold prodigiously high, and far exceeded even the exorbitant prices formerly fixed by the Emperor on forcign commodities ; so that the price of silk per pound was now six pieces of gold, being eight times more costly than before the introduction of the insect into Rome. This was the value of common colours, for the imperial purple was quadruple that price; so that the propagating of the animal, which, in other circumstances, and under a patriotic sovereign, might have been a boon to the empire, proved, under the sordid Justinian, rather a curse.

Things, however, could not long remain in this state, for ways and means were found to convey the Silkworm Moth to Greece and the Peloponnesus, in whose genial climates they quickly increased; and the sovercigns of these states, actuated by more generous views, multiplied the growth of mulberrytrees, extended the manufacture of silk, and soon rendered their empire independent of those supplies which they obtained through their mercantile intercourse with Persia.

In the middle of the sixth century the Turks established themselves in Asia, and their frequent subsequent wars had tended greatly to impede the traffic carried on betwixt China and Persia, through the caravans, consequently, silk in P'ersia had assumed a high value from its scarcity.

After the establishment of the peace, Maniak, a 
prince of Sogdia, through the wishes of his people, was appointed ambassador by the Turkish court, to mediate with Persia for supplying that nation with Eastern silk. This prince acted in the twofold capacity of an envoy and a merchant. He took with him to Persia a number of bales of the manufactured silk, which he expected to sell readily, in consequence of the price at which he could afford to dispose of them being so much lower than in Persia at the time. But the results of this embassy proved different to what tho Sogdian prince expected.

At this time Persia was under the sway of Chosroes, a king, who, to a love for his people, united soundness of policy. He wisely saw that it would tend to no good to increase the wealth of a prince whose territories lay so close to his own, and who had been actuated by schemes of ambition. To show, therefore, his contempt for the merchandise of the Sogdian prince and his mercantile followers, he purchased up all their goods, and to prove how little he valued them, committed the whole to the flames. Besides the motives above stated, he considered it would be more for the advantage of his people to carry on a direct traffic with China through the Gulf of Persia. In the furtherance of these views, an alliance was entered into between the Persians and Chinese, to the exclusion of the Turks, who, in their turn, sought the aid of the Romans. They again appointed Maniak as envoy to Persia, but 
that prince had the mortification to find, at Constantinople, not only the Silkworm feeding in healthful vigour, but also extensive manufactories established for weaving different fillories. He, however, had the address to conceal the chagrin he must have experienced, and, even with a degree of flattery, corresponding to that of a more civilized prince in modern times, complimented the Romans on the progress they had made, and assured them their manufactories were equal in quality to those of China, and their management and culture of the worms were not less successful."

Although the culture of these insects turned out as successful as possible, still a considerable number of years clapsed before silk became a cheap article. As a proof of this, we find, that, in the year 790 , the Emperor Clarlemagne considered silk as a gift worthy of royalty, for he presented Offa, King of Mercia, with two vests made of that substanec.

$\Lambda$ bout this time the Venetians opened a commercial treaty with the Greeks, for the purpose of supplying the west of Europe with silks, the manufacture of that nation.

It was well for Europe that the Silkworm had been so successfully introduced as to render the importation of Chinese silk unnecessary. For a

- See Giввоn's Decline and Fall of the lloman Empire, chap. xîi. 
eircumstance occurred in the year 877 , which for a time completely put a stop, to the manufacture of silk in China. Biacha, a desperate insurgent, seized the reins of the Chinese empire, put to death all the foreign merchants of Canfu, and directed that the whole mulberry-trees on which the larve of the Silkworm Moth were fed should be cut down, so that there was not a particle of silk produced during his reign.

Massoudi informs us that Canfu, in the year 988 , was again the resort of Arabian merelrants, and also of trading vessels from India.

The Roman empire began to decline about the year 1146, yet that enterprising people still maintained their superiority in the manufacture of silken stuffs of various linds; having leen the snle possessors in Europe of the Silkworm for a period of more than six hundred years. 


\section{THE HISTORY OF SILK DURING THE MIDDLE AGES.}

THE culture of the Silkworm Moth now became an object of universal attraction, and there was hardly a nation at all civilized which did not wish to participate in the benefits which were derived from so important an acquisition.

Roger the First, King of Sicily, having waged war against the Grecian empire, and successfully invaded her territories, carried off as plunder all the moveable wealth of Corinth, Thebes, and $\Lambda$ thens ; and having seized the persons of many of the most expert weavers of silk, brought them captive to Palermo, where he established a manufactory, and compelled these unfortunate men to make known to him the secrets of the art.

Here we have another instance of good resulting from evil ; for from these unoffending artisans, who were wantonly torn from the bosom of their families and their country, the general dissemination and 
knowledge of this important trade found its way through all parts of Europe. WVe have scen that, for the long period of six hundred years, this manufacture was confined to the Roman power, and carcfully kept secret from neighbouring states.

In the short period of twenty years, we are informed that the Sicilians had attained a much ligher degree of perfection in the manufacture of silk than the Greeks, both as to splendour and diversity of the patterns, and the brilliancy of the colours. They introduced into different textures golden threads, wrought into fanciful figures; and in other fabrics, pearls were intermingled. From this period may be dated a decided improvement in the national eharacter and prosperity of that kingdom, which now became the centre of attraction to the whole western hemisphere. It now began to spread itself all over Italy, where it became an article of great commercial importance, and continues to this day a staple commodity.*

It is quite certain, that in the year 1306 , the progress of rearing Silkworms had arrived at such a pitch in Modena, that the manufacture of silk contributed largely to the revenue of the state, and was considered the best which was made in Lombardy. Whether to augment the revenue, or to

- Otho Friesing, De Gest. Frederici. 1. i, cap, 33. 
increase this manufacture, is not known, but an edict was passed, obliging every person possessed of an cnclosure to plant at least three mulberry-trees, and compelling the cocoons produced from all Silkworms to be solel in the public market, and a tax exacted both from the selier and purchaser.

Nutwithstanding the high perfection of the Modonese in weaving silk, yet they were not possessed of any throwing mills, and were, in consequence, obliged to send all their raw silk to Bologna to be thrown, being the only place in Italy where there were mills for that purpose.

From Italy Silkworms were introduced into Spain, where they made but little progress, owing to the unsettled and ille habits of the pcople, who appear to have preferred purchasing silk goods in a forcign market, rather than entering with zeal into the manufacture themselves.

It is quite uncertain when the use of silk was introduced into England, but it appears to have been of a date considerably subsequent to its being common in France. But circumstances lead us to infer that it must have been shortly after the Norman Conquest. The Chronicles, however, inform us, that silk was pretty gencrally adopted amongst the nobility both of England and Scotland, in the year 1251. At this time, Alexander the Third of Scotland married Margaret, daughter of Henry the 
Third of England, on which occasion the princess had in attendance a thousand knights dressed in cointises of silk.

After this period, however, silk seems to have been less fiequently worn in Britain, but from what cause we can find no account.

Florence had attained a high degree of excellence in silken fabrics so early as the year 1300 , at which time many thousands of people were employed in this art.

Venice in its tum became famous for silks, the manufacture of which was considered a fitting cmployment for nobility, who thought it no disgrace to assist in producing this elegant article of dress. This policy is quite at varianee with the modern ideas of the European aristocracy, who consider all employments, save war, the church, and law, as degrading to their rank.

A bout this time the whole of the Christians were expelled from Syria, by which the Egyptian rulers contrived to make that country the medium through which all the silk inported westward must pass. By this means they added a great revenue to the state, by the exaction of heavy duties, which were severely felt by the Italians and other nations who used foreign silk. This excited the indignation of a learned and noble Venetian named Marino Sanuto, who wrote a book on the sulject in the year 1321, and addressed it to the Pope. It bore the fanciful 
title of "Secrets of the Faithful," in which he wished to instigate the holy father to suppress these grievous exactions by hostile measures, and recommended, as a prudent step, that his countrymen should forbear using Chinese silks, averring that the quantity produced in Crete, Sicily, Romania, A pulia, and Cyprus, would be sufficient, if attention were directed to the extended propagation of the worms. He implores all true Christians to abstain from the purchase of any silk merely suspected to have come through the hands of these infidels. He recommended the establishment of galleys to intercept smuggling.

So rare were silks in the reign of Edward VI, that Sir Thomas Gresham presented that monarch with a pair of Spanish long silk hose, which the king considered as a high compliment, from their rarity; and that extravagant king, Henry VIII, seldom wore silk stockings except upon great occasions, and these he procured from Spain. Queen Elizabeth, in the third year of her reign, $(1560$, ) was presented by her silk woman, Mrs Montague, with a pair of silk stockings, which so greatly delighted her, that she never afterwards wore cloth hose. But we du not find that the manufacture made any progress during her reign.

By slow degrees part of Spain had now acquired considerable reputation for different falbrics of silk, and manufactories of some conseruence had been 
erected, particularly in the province of Granada, then under the dominion of a Moorish prince.

In France, the silk trade experienced a considerable improvement during the reign of Francis $I$. At that period Milan was under his yoke, and from thence he carried weavers to Lyons, and cherished by all means the progress of the trade. This gave a spirit to the manufacture, and was the means of spreading a taste for it in several of the neighbouring provinces. And so rapidly did these arts improve and extend, that they soon were cnabled to export to England and other countries great quantities of their silken goods.

Some historians say, that the Silkworm was introduced into France in the reign of Charles VIII, at so early a period as the fifteenth century, by some of his noble followers in his Italian campaign; while others assert that it was brought from Sicily. It secms quite certain that the mulberry-tree was first introduced from the latter country, and that the Silkworm Moth was not propagated in Provence till the reign of Henry IV, whose anxicty to establish the insect more generally, prompted him to make extensive nurseries of mulberry plants, and be gave them gratis to every one desirous of possessing them.

It appeared to him, that as mulberry-trees were plentiful in his kingdom, he might render an essen- 
tial benefit to his people by the propagation of an insect which was of such great commercial importance to other states. It is a curious fact, that Sully, whom the king generally consulted on any important measure, used all his eloquence to dissuade him against the measure, who, in opposition to an opinion which he generally respected, imported the insect, which throve amazingly, and the result was soon crowned by a successful and beneficial establishment of numerous silk manufactories in different provinces throughout the kingdom.

The inercase of demand for silks in England attracted the attention of Queen Mary, and, to check the pride of the citizens, which appeared to her as too aspiring, she, in the year 1554, enacted, "That whoever shall wear silk in or upon his or her hat, bonnet, or girdle, scalubard, hose, shoes, or spurleather, shall be imprisoned during three months, and forfeit ten pounds." Magistrates of corporations and esquires were exempt from the penalties of this statute.

During the reign of James I. of Scotland, silk was a very rare article in his kingdom; for we are told that that monarch had not a pair of silk stockings in his possession when he was to receive the English ambassador, and had to apply to a subject, who, it appears, was better provided, for the loan of a pair. This was the Earl of Mar, to whom the king said, in an impressive manner, "You would not, sure, 
that your king should appear as a scrub before strangers."

Antwerp, which was long the great mart for silk, and the produce of almost all nations, was taken by the Duke of Parma in 1585, and given up to be plundered by his army for three days. This disastrous event proved the destruction of the commerce of the Netherlands. The splendid manufactures of Brabant and Flanders were annihilated, and the artisans dispersed and took refuge in foreign states; nearly a third of them found their way to Britain, and laid the foundation of those manufactories which are now an honour to the land. It was long, however, before the goods of our own country were much noticed, the preference being given to those of foreign manufacture. So completely were our own fabrics neglected in the year 1668 , that it led almost to a total ruin of the trade, nothing pleasing our families but French goods; and the merchants said at the time, that the women's hat s were turned into hoods made of French silk, whereby every maid-servant became a standing revenue to the French king of half her wages. 


\section{THE MODERN HISTORY OF SILK.}

FEW articles of commerce are more valuable to mankind than silk. It is extensively cultivated in many of the most populous provinces of southern Europe, and excites as deep an interest among the inhabitants as the crops of flax, hemp, and even grain in the northern countries. The prospect of $a$ failure creates a panic nearly as great as the prospect of a famine.

In its first production, silk furnishes employment to many thousands, and nearly as great a number in its transportation to foreign lands. In the course of its being manufactured, it furnishes employment and subsistence to hundreds of thousands, and, besides, gives an impulse to the circulating medium of almost all countries, probably in greater degree than almost any other mercantile traffic.

It is not to Europe alone that this valuable article is of such momentous interest, for, in China and India, silk is cultivated to a still grenter extent 
than in Europe, and with more success, as the climate of those regions is more congenial to the energies of the insect which produnes it. And, moreover, we have seen that it has been an article of dress in these countries from time immemorial, whereas, in Europe, its introduction is comparatively of modern date.

At the end of the sixtcenth century, an absurd prejudice continued to prevail in England against our own silken fabrics; but still the manufacture of it was steadily pursued, and the texture gradually improved. At this time, the Rev. William Lea, of St John's College, Cambridge, invented a machine for weaving stockings, which was the first means of setting aside the uncomfortable and unshapely hose which were generally worn at that period. The superiority of these soon attracted universal attention, not only at home, but also abroad; and silk stockings wrought on these machines werc eagerly sought after in Italy and other continental states. Great quantities were exported to Italy, where they long maintained a high character for superiority. Keyslar informs us, that, " at Naples, when a tradesman would highly recommend his silk stockings, he protests they are right English." *

Mr Lea, like many other men of genius, whose inventions have benefited mankind, did not meet

- Travels through Europe in the year 1730. 


\section{THE MODENN IISTORY OF SILK.}

with the encouragement, in England, which his important discovery merited. That enlightened monarch, Henry IV. of France, hearing of the machine, and of the neglect of it by the English, invited Mr Lea to settle in his country, and assured him of his countenace and support. He accordingly accepted the invitation, and, accompanied by a number of journeymen weavers, passed over to Rouen in Normandy, where he established a manufactory of silk stockings. The troubles in France which followed the assassination of Henry IV. forced him to abandon his enterprise, and, finding his way to Paris, in hopes of some encouragement, in which he was disappointed, he died in abject destitution.

Henry IV. considered the introduction of the silk trade of such consequence, that he stimulated the Parisians, and others of his subjects, to cultivate it by every means; and even the rank of nobility was given, as a reward, to those who might be able to maintain successfully for twelve years a manufacture of silk, from the produce of worms bred in France. This had the effect of producing much emulation, and the trade assumed a very flourishing condition. He caused many mulberry-trees to be planted in the vicinity of Paris, and even bred Silkworms at the Tuilleries, Fountainbleau, and the Castle of Madrid. The king, had previously made the same efforts to propagate the insect, and planted the mulberry at Provence, Lyonnois, 
Languedoc, Vivarais, Gascony, Saintonage, and Dauphine; and subsequently tried almost every other part of his kingdom. But experience taught him, that the Silkworm could not be successfully propagated north of the river Loire.

In the reign of Louis XIV, Colbert, minister of that monarch, evinced such anxiety for the extension of the silk trade, that he not-only gratuitously supplied the possessors of land with nulberry-trees, but also caused them to be transplanted at the expense of the government. This did not, however, facilitate the progress of the culture of silk; for the trees, so easily acquired, were little valued, and even wasted by the peasantry. The minister, finding his views frustrated, adopted another premium for encouraging the growth of the mulberry. He gave, for every tree which presented a thriving condition three years after it was planted, the sum of three livres.

King James I. of England, seeing the benefits which accrued to the French people through the zeal of their sovereign, resolved on adopting similar measures for encouraging the growth of mulberrytrees, and multiplying the breed of Silkworms. In the year 1608, his majesty caused a circular to be addressed to all the counties of his realm, recommending, in the strongest terms, the planting of mulberry-trees, advising all who had the means to purchase in London ten thousand plants, which were then selling at three farthings. But it was not till 
it was generally known what advantages had been reaped by the French, and other continental kingdoms, in this trade, that the rich generally adopted the recommendations of their sovereign. So averse were our countrymen to exert themselves in this lucrative trade, that it was nearly twelve years before a taste for the manufacture was matured. At length every effort was used, but in vain, to extend the number's of Silkworms. When it was discovered that the climate of Britain was not congenial to the propagation of the insect, the hopes that were entertained soon began to die away, and in a few years the experiment was in a manner abandoned as hopeless.

The king, finding his projects frustrated at lome, now turned his thoughts to his colonies; and he was advised, that the climate of Virginia was of such a temperature, that the insect might there be suecessfully cultivated. He wrote the Virginian Company a very particular letter on the subject, recommending that they should substitute the cultivation of mulberry-trees, and rearing of Silkworms, for the growth of tobacco, which he considered a "pernicious and offensive weed."

The Virginian Company entered heartily into the king's riews; and being furnished with a work written by one of the Company, Mr Joln Bonoeil, on the Culture of the Silkworm, they entertained notions that they would speedily be enabled to produce such 
a quantity of silk, that they could supply the half of the world. But a series of untowardevents frustrated the hopes of the Company, which was soon after broken up by the misfortunes that befel the colony. And although a subsequent attempt was again made in 165. by the Virginians, at the instigation of $\mathrm{Mr}$ Edward Diggs, yet, from some cause with which we are unacquainted, the silk trade never flourished in that state.

In the year 1629, King Charles I. made an attempt to revive the produce of Silkworms in England, by granting to Walter Aston the kecping of the garden, which had been established near St James's, in the county of Middlesex, for the rearing of Silkworms, which had still been partially maintained. This attempt was again rendered abortive, from cold seasons and other causes.

The rearing of the Worm seems to have been in a dormant state, from the above period, for nearly ninety years, when King George I. granted a patent to John Appleton, for the producing of raw silk in England. This gentleman was to raise the funds necessary for the purpose, by a joint stock concern, the capital of which was to be divided into five pound shares. $\Lambda$ lease of Chelsea Park was obtained for the period of one hundred and twenty-two years, and two thousand mulberry-trees were planted, as a small portion of what was ultimately intended. Various large factories were built; but this great establish- 
ment was soon abandoned, and the experiment proved as unsuccessful as the previous ones made to raise the Silkworm in this country. The highest expectations were conceived of this project, and Henry Barham, a shareholder, wrote and published an essay, wherein he attempted to show, that all the former attempts had been rendered abortive from mismanagement; and gave it as his opinion, that the objections then thrown out, as to the ultimate success of "this glorious undertaking," were not worthy of refutation.

King George looked with a favourable eye towards the encouragement of the breeding of Silkworms ; and on the establishment of the colony of Georgia, in 1732, he directed that a piece of ground should be set apart for propagating the white mulberry; and the settlers were induced to rear Silkworms, in which they were pretty successful, and also in the quantity of silk produced. From Georgia the rearing of these insects found its way into the neighbouring state of South Carolina, where it also soon became an article of some commercial interest.

In the succeding reign, the government, anxious, if possible, to render England independent of foreign supplies of silk, endeavoured to encourage the production of it in our colonies. For the furtherance of this object, an act of parliament was passed in the year 1749 , for the purpose of encouraging the growth of silk in the colonies; and a provision of that act 
was to exempt from duty, on entering the port of London, all silk the produce of Carolina and Georgia. Under such favourable circumstances, these colonies greatly extended their culture of this article; and the government entertained sanguine hopes of their protection of the trade proving ultimately a source which would supply all the demands of the British silk-weavers, if still farther encouragement were afforded to the colonies in question. With this view, Mr Ortolengi, an Italian, well accquainted with the management of the worms, and every other department of the raw silk trade, was engaged to instruct the Georgians in the modes so successfully practised in his native country. This scheme was at first attended with considerable success, and the hopes of the colonists were considerably elevated. But, alas, how uncertain are human affairs ! for several seasons followed in succession unfavourable to the silkworms ; and this, with the indifferent quality of the silk, and government reducing the bounty, proved a death-blow to the flattering prospects of the Georgians and Carolineans, and the principal planters abandoned the culture of the Silkworm in despair. By the end of the eighteenth century, the Silkworm was unknown in these colonies.

The manufacture of silk was introduced into England in the fifteenth century. Its early progress was, however, far from being rapid; but it gradually increased, according as the growing wealth of the 
country occasioned a greater demand for silk goods. The silk throwsters of the metropolis were united in a fellowship in the year 1562 , and were incorporated by royal charter in 1629. So prosperous and flourishing had their business become, that it is stated, in the preamble to a statute passed in $\mathbf{1 6 6 6 ,}$ (13 and 14 of Charles II, cap. 15,) that they had at that time no fewer than forty thousand individuals in their employment! And it is of importance to observe, that though the importation of silk goods from forcign countries was occasionally prohibited during the reigns of James $I$, and Charles $I$, the Protectorate, and the reign of Charles II, the prohibition was not strictly enforced; and, generally speaking, the importation of these goods was quite free.

A considerable stimulus, though not nearly so great as has been commonly supposed, was given to the English silk manufacture by the revocation of the edict of Nantes, in 1685. Louis XIV. drove, by that intolerant and disgraceful measure, several hundred thousands of his most industrious subjects to seck an asylum in foreign countries; of whom, it is supposed, about fifty thousand came to England. Such of these refugees as had been engaged in the silk manufacture, several branches of which were then in a comparatively advanced state in France, established themselves in Spitalfields, which has continued ever since the principal seat of the British 
manufacture. At the period of the influx of the refugees, foreign silks were freely admitted into England; and it is stated, in the custom-house returns, that from $\mathcal{E} .600,000$ to $\mathcal{E} .700,000$ worth were annually imported in the interval from 1685 to 1693 . But the manufacture was not long permitted to continue on this footing. In 1692 , the refugees, who seem to have been quite as conversant with the arts of monopoly as with those either of spinning or weaving, obtained a patent, giving them an exclusive right to manufacture lutestrings and i-la-modes, the silks then in greatest demand. This, however, was not enough to satisfy them; for, in 1697, Parliament passed an act, in compliance with their urgent solicitations, prohibiting the importation of all French and other European silk goods; and, in 1701, the same prohibition was extended to silk goods imported from India and China.

The year 1719 is an important epoch in the history of the British silk manufacture, a patent having been then granted, for fourteen years, to Sir Thomas Lambe and his brother, for an exclusive property of the famous silk mill erected by them at Derby, from models they had clandestinely obtained in Italy, for preparing thrown, or, as it is more commonly called, organzine silk. At the expiration of the patent, Parliament refused the prayer of a petition of Sir Thomas Lambe for its renewal, but granted him a sum of $\mathcal{L}^{\prime} .14,000$ sterling, in consideration of the 
services he had rendered the country, in erecting a machine which was supposed would very soon have the effect to enable us to dispense wholly with the supplies of thrown silk we had previously been in the habit of importing from Italy. But, instead of being any real advantage, it is most certainly true, that the establishment of throwing mills in England has proved one of the most formidable obstacles to the extension of the silk manufacture. These mills were originally constructed in consequence of the heary duties laid upon thrown, or organzine, silk; and the cireumstance of their having been erected, and a large amount of capital invested in them, has been urged, and, till lately, with success, as a reason for continuing these high duties.

From this period the manufacture advaneed gradually, though slowly, until about 1785 , or 1790, when the general substitution of cottons for silk, in articles of dress and furniture, gave it a check from which it did not recover for some years. So rapid was the change of fashion, that, in Spitalfields alone, about four thousand looms were shut up in 1793 ; which, when in full work, seven years before, had given employment to about ten thousand persons.

The trade experienced an evident revival between the years 1798 and 1800 , and has made an astonishing progress within the last fifteen or twenty years. This has been, in no inconsiderable degree, 
owing to the facility with which increased supplics of raw silk are now obtaincd from India. In 1770, the East India Company began to introduce the Italian mode of preparing and winding silk into Bengal ; but the obstacles to its introduction, from the ignorance and prejudices of the natives, and other causes, rendered its progress for several years comparatively slow. The average quantity of raw silk imported from India previously to 1770 , did not exceed one hundred thousand pounds weight; and this, too, of a very inferior description, and worth only from a third to a half of Italian silk. In 1780, the imports from India amounted to about two hundred thousand pounds weight; and, in 1800 , to nearly five hundred thousand pounds weight. Since that time they have continued to increase in a still greater proportion, the quantity of Bengal silk imported in 1823 having been upwards of one million two hundred thousand pounds weight, and of an exceedingly improved quality. The price of Italian raw silk is stated in the Second Report of the Lords' Committee on Foreign Trade, (page 4,) to be from thirteen to twenty-six shillings a pound, exclusive of duty, and that of Bengal from twelve to twenty-five shillings a pound. But as only one crop of raw silk is annually produced in Italy, while from teco to three crops are produced in the same period in India, a very great reduction of price may be expected the moment these absurd 
and jealous regulations are removed, which now prevent the free application of European capital and skill to the culture and preparation of Indian silk.

The following is an official account of the quantities of raw and thrown silk imported into Great Britain in the year ending the 5th January 1824:

\begin{tabular}{|c|c|c|c|}
\hline $\begin{array}{l}\text { Countriess from whence } \\
\text { lmyerted. }\end{array}$ & Raw Silk. & $\begin{array}{l}\text { Thrown } \\
\text { silk. }\end{array}$ & Total. \\
\hline 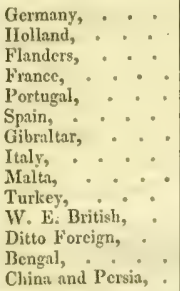 & $\begin{array}{r}35,689 \\
1 \\
1,171 \\
396,3551 \\
179 \\
1,3001 \\
5,7841 \\
196,7871 \\
381 \\
203,059 \\
44 \\
\\
1,218,6619 \\
932,717\end{array}$ & $359,640\}$ & 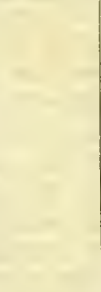 \\
\hline Lbs. & $2,452,130$ & $359,6+1 \frac{1}{8}$ & $2,811, \pi \pi 11$ \\
\hline
\end{tabular}

During the same year, the exports amounted to only fifty-three thousand six hundred pounds weight, of which forty thousand were to Ireland. The imports of silk into Britain during the year ending 5th January 1825, amounted to three millions, three hundred and eighty-two thousand, three 
liundred and fifty-seven pounds weight, of which one million, seven hundred and sixteen thousand, seven hundred and thirty-two pounds, were furnished by Italy, and one million, three hundred and seven thousand, three hundred pounds, came from the East Indies and China.

In the year 1825, the silk trade was at a high pitch; and, as a staple article, added greatly to the revenue of the country, as will be seen from the above table, exhibiting the immense quantity of raw silk imported. Besides, it afforded employment to a great many individuals. Mr Wilson, a well informed and extensive silk manufacturer of that time, said, "I calculate that forty thousand are employed in throwing silk for the weaver, whose wages will, I think, amount to $\mathcal{L} .350,000$ sterling. I estimate that half a million of pounds of soap, and a large proportion of the most costly die stuffs are consumed, at a farther expense of $\mathcal{L} . \$ 00,000$; and that E.265,000 more are paid to sixtecn thousand five hundred winders, to prepare it. The number of looms may be taken at forty thousand, and, including weavers, warpers, mechanics, harness makers, enterers, twisters, cone-spreaders, quillwinders, and draw-boys, at two hands to a loom, will employ eighty thousand more persons, and the wages amount to three millions sterling. If we include infants and dependents, about four hundrerd 
thousand mouths will be fed by the silkmanufacture, the value of which I estimate at TEN MILLIONs." * At the same period, $\mathrm{Mr}$ IIale of Spitalfields estimates the number of persons supported by the silk manufacture at five hundred thousand; but this was probably too high an estimate for the time. Since that time, however, the trade has greatly increased, and we have no doubt but half a million must be somewhat near the number now employed.

These statements are sufficient to show the very great and increasing importance of the British silk manufacture. So extended and rapid has been its improvement, that it has now become of considerably greater magnitude and ralue than that of France! M. Chaptal, who had the best means of obtaining accurate information on the subject, states, in his valuable work, that "France does not, in ordinary years, produce more than a million of pounds of raw silk, and that the whole quantity consumed in the French manufacture, is not more than double that amount." Neither is it in extent only that we have begun to surpass our ingenious and enterprising neighbours; for, though they still continue to excel us in the manufacture of the lighter fabrics, we have obtained an unquestionable superiority over them in

- Second Report of the Lords" Committer, p. 39. + Sur l'Industrie Françoise, tom. ii. p. 118. 
the manufacture of gloves and hosiery, as well as in that of poplins, tabinets, and all those mixed fabrics of which silk is the basis, and we are also already rivaling them in the brightness of our colours and the durability of our dies. The existing prejudice in favour of French silks, is, beyond all doubt, to be ascribed principally to the difficulty of obtaining these articles; for, it is stated in the evidence before the Lords' Committee, that the greater proportion of the silks professing to be smuggled, disposed of in London and other places, is of British manufacture,-brought from Spitalfields and Manchester, -and not, as our ladies implicitly believe, from Lyons and Marseilles.

About the year 1780, the breeding of Silkworms was again revived in Britain. We find, from the Transactions of the Society for the lincouragement of $\Lambda \mathrm{rts}$, Manufactures, and Commerce, that, on the 1st February 1785, the silver medal was awarded to Miss Hemietta Rhodes, of Cann Hall, near Bridgenorth, for her sedulous attention to, and judicious observations on, the breeding and treating of Silkworms.

To show their progress and rapid increase, we may mention, that Miss Rhodes got a dozen of Silkworms in $178 \%$. She was then quite unacquainted with the mode of treating them ; but, by care, preserved them in health, and they produced a number of eggs. 
In May 1783, about thirteen hundred larvæ werc produced from the eggs, and she was so fortunate as to lose very few during the whole time of feeding, and obtaincd from them twelve hundred and seventyfive cones, which produced nearly four ounces of fine silk. All the eggs laid by the moths after their transformation were carefully preserved, aud, on the 12th of the succeeding May, she placed them in the sun, when they hatched in incredible numbers; and although she did not count every caterpillar, she supposed them to amount to more than ten thousand. She fed them with lettuce leaves for the first week, and then from three or four mulberry-trees, which grew in some adjacent gardens. However, as they grew larger, they became so extremely voracious, that Miss Rhodes felt the utmost apprehensions lest a famine should ensuc. Her solicitude for the animals increased her exertions, and she sought after mulberry-trees with devoted anxiety, and the acquisition of a new one gave her great satisfaction. By perseverance her resources were augmented to the number of twelve trees, although some of them were at the distance of twelve miles from her residence. Such was the quantity these creatures devoured, that a bushel of leaves, crammed in as close as possible, would frequently be insufficient to support them one day.

Miss Rhodes had high anticipations of success, but a dreadful night of thunder in the latter end of 
June, which spread general alarm throughout England, deprived her of thousands of her insects. On visiting her manufactory carly next morning, she found that the lightning had struck several of the pans; at least such was her belief, for she could not believe that the sound of the thunder should occasion such appearances. A large pan immediately opposite to the window, containing about five hundred Silkworms, was full of a liquor as yellow as gold, and all the little animals who had been its inhabitants were dead, and scorched up as by the influence of fire, while others of the pans had only been partially affected. She removed all the dead: but her misfortune did not end there, for three succceding days presented her with such numbers who had equally felt the baneful effects of the lightning, that her immense stock was reduced to two thousand eight hundred and ninety-three: these were, however, exceedingly healthy, and began spinning their cones on the 7th of July.

During all this time Miss Rhodes had no other assistance than a servant; the pans were cleaned out once a-week, and the animals fed three times a-day. So small a portion of her time was taken up by attending the worms, that neither lier amusements nor avocations were interrupted by it.

Miss Rhodes found, that the average number of three hundred and sixty cones produced an ounce of silk; and she had, from the remainder of her stock 
of that summer, exactly half a pound of silk, all of one uniform colour and height of gum. She had, besides, of the waste silk with which the cones are surrounded, somewhat more than a quarter of a pound, which she had carded and wove into stockings at Nottingham.

From the statement given by Miss Rhodes, it would appear that it requires thirty thousand to produce five pounds of silk; and she found that ten mulberry-trees, absolutely stripped, were barely sufficient to supply the wants of ten thousand caterpillars. She tried to feed worms on all the different leaves of a large and variously stored kitchen-garden, but they would not eat any but lettuce and spinage, and they perished on these in a very short time, owing, she imagined, to their moisture and coldness.

The criterion to judge of the goodness of silk is, by the height of the gum ; and that of Miss Rhodes, in that respect, outstripped Italian silk. She accounted for it in this way, that in Italy the chrysalis soon bursts, and the imago is destroyed to prevent them eating their way out of the cone, in which case they are sure to injure the silk; and, to effect this, they are placed in heated ovens. In Britain, where progress is slower, there is sufficient time to wind off the silk, without killing the chrysalis. Miss Rhodes frequently wound the cones out of boiling water, placing them afterwards on dry paper, and 
she always found that the chrysalis was uninjured by this mode of treatment, and that the moth was regularly transformed at its proper time.

If, therefore, the chrysalis can bear so great a degree of heat as boiling water, it is obvious that the warmth of the ovens, and the length of time it is necessary to keep it there, to ensure its destruction, must greatly injure the strength and glossy hue of the silk. But this is not all, for in Italy they suffer the moth to eat its way out of the largest cones, in order to have eggs from the most healthy, and thereby lose all the silk in those cones. Here, the silk may be gathered, as well as the moth preserved; and thus do we possess two striking advantages, which amply compensate for the loss of many others.

In the year 1785, Miss Rhodes again tried the rearing of the Silkworm; but, owing to the difficulty of procuring mulberry-trees, she greatly limited the numbers, preserving only as many eggs as covered a sheet of writing-paper. In order that the worms might have the adrantage of the hottest summer months, these eggs were not exposed until the morning of the first of June; and, before night, some hundreds were hatclied, and, in a day or two, the whole made their appearance. As she had convinced herself, from experiments, that lettuce was the only food which could be relied upon next to the mulberry, she caused some large beds to be carefully cultivated. She then made trial how long 
they would subsist upon these without injury to their growth, or the produce of the texture of the silk. They were so fine and healthy, that she fed them solely with lettuces till the 24th of June, being twenty-four days, or double the time they used to be kept from the leaves of the mulberry-tree.

In less than a week after this change of food, laving attained their full growth, and exhibiting that beautiful transpareney which predicts their maturity, they began to spin, and produced cones as fine and firm as any she had ever had before.

By the latter end of July the whole business was completed, and she wound exactly four thousand cones, which produced eleven ounces of silk, precisely the same as that of the preceding ycar.

Miss Rhodes did not lose more than a dozen of worms when feeding; and, from the size of the cones, thought they were equal to any produced in Italy.

In a treatise on the Silkworm Moth, published in Georgia, it appears that the cones of the caterpillars fed in that country contain three hundred yards of silk, which weighs no more than two grains. Miss Rhodes measured the thread of a cone of her own breeding, and found it contained four hundred and four yards of silk, which, when dry, weighed three grains; and this was from one of the worms which fed only one week on mulberry lenves.

Various kinds of leaves have been employed in 
feeding Silkworms; such as those of cowslips, blackberries, and the young leaves of the elm. Miss Rhodes, however, found, upon trying the latter, that nine out of a dozen worms died, and the other three were rescued from the same fitte by giving them the mulberry leaf; but they never recovered their strength sufficiently to form a cone. So that none of these lcaves can be used to any practical purpose. Their employment can only gratify the curiosity of the speculative philosopher.

The Hon. Daines Barrington suggested the idea, that all those leaves which were similar to the mulberry in taste and appearance, - such as the filbert, currant, lime, kidney beans, strawberry, chestnut, raspberry, ash, pine, \&c. might be successfully employed in breeding Silkworm caterpillars; but none of them have been found to answer. They will eat the cabbage leaf in preference to any of these, and that even sparingly. But the offensive smell of these leaves renders them unfit for use in a large manufactory.

It is a singular fact, that no other species of lepidopterous insect is found to feed on the leaf of the mulberry-tree but the Phalcena mori, or Silkworm caterpillar. This tree, indeed, secms to be secure against the ravages of all other insects; which circumstance must excite our admiration of the divine Creator, who, in his beneficent goodness, has bountifully secured food to the insect whose labours were 
to be of the greatest service to man. In whatever way we turn our eye, the economy of Nature abounds in self-evident marks of divine goodness and wisdom.

In the uncertain and changeable climate of Great Britain, there is much difficulty in naturalizing any foreign animals, especially those of more genial climates; and, were it not that the eggs of lepidopterous insects are capable of resisting a great degree of cold, many species would necessarily become extinct in severe winters.

In the year 1786, Miss Rhodes had every reason to anticipate a successful scason with her colony of Silkworms; having bred upwards of thirty thousand, from which she calculated on a produce of five pounds of silk. They were extremely healthy, and supplied plentifully with food, through the bounty of her friends, who sent leaves daily, even from a distance of fifteen miles.

A bout the beginning of July, the caterpillars had attained their full growth, and exhibited a disposi tion to spin; but, at this crisis, a chilling north wind set in, accompanied by a degree of cold little less severe than some of the winter months. Its baneful effects were visibly displayed on Miss Rhodes's little colony. Those that were ready to spin became of such icy coldness, that it was scarcely possible to bear them on the hand; they made some feeble efforts to eject the thread from their mouths, 
but in vain, for they shrunk into the chrysalis state without being able to form even the web which encloses the cone. "This," says Miss Rhodes, "was equally new and alarming to me, and I watched them with the most anxious attention. The principle of life was as visible in them as in the chrysalises which they had spun. That this change was the effect of cold, I had no doubt; but I wished to discover how that effect was produced, and this I could only do by opening some of them. On examination, I found that the glutinous matter which forms the silk was become so highly congealed by the cold, that it resembled a strong tendon, both in appearance and tenacity; whereas I had ever found it to be perfectly fluid in those worms which were employed in spinning.

" My distress increased hourly, for thousands went off thus every day. It was sufficiently obvious that the making of fires would remedy the evil; but they were unfortunately situated over a range of warehouses, which rendered that not only dangerous, but impossible. To remove such numbers into the house was equally impracticable ; but, alas! they were soon sufficiently reduced for me to adopt that plan; and, in one of the coldest days I almost ever felt, with the assistance of several of my friends, I removed them to their former apartment. There $I$ kept large and constant fires; and the worms, as 
they arrived at maturity, pursued their industrious occupation with alacrity.

"From this it will be perceived, that cold, though it impedes their growth, does not essentially injure the worms until they arrive at the state for spinning; and that then a certain degree of heat is requisite to render the silk sufficiently fluid for them to eject it with ease. If $I$ could have made fires at the first, I am sure that the dreadful havoc would have been prevented; and those who rear them for profit may readily construct places where an artificial heat may counteract the effects of an uncommon season, and prevent such a calamity. I have abundantly established the following facts:-

"First, That the management of the Silkworm is by no means difficult; the principal objection having been obviated by the discovery, that they may be supported so long a time on an indigenous plant, which may be procured in all situations.

"Second, That our climate supplies a sufficient degree of warmth to bring the Silkworm to the highest perfection, unless in very extraordinary seasons, which may be guarded against by the construction of fire-places.

"Third, And that the profits which arise from the manufacturing of silk are immensely advantageous, one-fourth part of the price of silk bcing adjudged enough to pay the whole expenses." 
Mr Swain makes the following judicious remarks on the food of the Silkworm:- "That food," says he, "I am confident, will never be found in the leaves of any other tree or plant than those of the mulberry. For although Silkworms will feed on the leaves of lettuces, and will sometimes spin their web, and go through their several netamorphoses without any other food, when they have been accustomed to that from their first exclusion from the eggs, yet they will never thive so well, become so large, or spin a web, either so good in quality or so abundant in quantity, as when they have been fed during their whole existence in the larva state on their natural food, mulberry leares. And supposing the leaves of lettuces to be an equally proper food for them, yet the great extent of land necessary for. the growth of lettuces sufficient for the consumption of any considerable number of worms, must surely render ineffectual every attempt to raise silk upon that plan."

What necessity can there be for ranging in quest of other nutriment, when the mulberry-tree itself, the acknowledged proper and natural food of these insects, will thrive and prosper in this country as well as most other trees? In very poor soils, indeed, they grow sparingly. But in soils tolerably rich, either those that are naturally so, or enriched by art, they regetate with all the luxuriance that can be wished. 
The chief reason alleged for the necessity of finding out a substitute for mulberry-leaves is, that these leaves are not produced early enough in this climate to become the food of the infant worms. It is well known that the leaves of the mulberry-tree seldom begin to unfold themselves before the latter end of May, or the beginning of June. It is likewise a matter of notoriety, that those few Silkworms which have as yet been bred in this island, have mostly been hatched in the beginning of May, or even earlier. From hence there has been supposed a necessity of providing some more early vegetating plant for their food, before the leaves of that tree are ready for them. That no such necessity exists is very apparent. Is it not natural to conclude, that the constitution of the air, respecting warmth, should at one and the same time expand the leaf, and hatch the insect, which was intended by the all-wise Providence to inhabit and feed on that leaf? This, we may observe, is the constant course of nature, with respect to all other insects and their food. IVe have every reason to suppose that this is the case with the Silkworms, and the mulbery leaves, in those countries where both are indigenous; and there cannot be the shadow of a doubt, that this effect would naturally and invariably obtain as well in this climate as any other, did not human imprudence interpose to prevent it, and art obstruct the intention of nature. The eggs 
of Silkworms have, in this country, been generally consigned to the care of young people, and chiefly those of the female sex. They have been preserved in bureaus, and chests of drawers, in rooms where fixes have been constantly kept during the winter season. In the spring, as soon as the influence of the sun began to be powerful, the eagerness of youthful curiosity had caused them to be removed to windows, where the sun exerted its full power, or even increased in warmth by passing through the glass; and, in this situation, they have been generally forced into existence within a few hours, in a season when the temperature of the air was unfit for them, and their proper food could not be procured.

Mrs Williams has proved that the hatehing of eggs of Silkworm Noths may be accelerated, and has averred, that it is even possible to hatch them in the middle of winter; and Miss Rhodes proved that they may be retarded beyond the usual time. For she found that, in 1783, her Silkworm eggs were not hatehed until the $2 \mathrm{~d}$ of June, and not eveu then without being placed in the sunshine, and $\mathrm{Mr}$ Swain retarded them till the middle of June, when they were vivified by exposure to the influence of the sun's rays, the great source of life and light; and I have kept them over a whole season in a cold damp cellar, without their being evolved: from all which, it seems pretty evident 
that the eggs of Silkworms may be hatehed at almost any time. But certainly the most proper season is at the time the mulberry is in leaf, at least to those who engage in the breeding of them for mercantile purposes.

The chief reasons for recommending the full foliation of the mulberry-tree, for the regulation of this matter, are these: The first is, that there may be a sufficient store of their natural food ready for the young worms as soon as they are excluded from the eggs, which will preclude all necessity for seeking after other food. A second is, that these worms being originally natives of a warm climate, may be sure to be brought to life when the air is of a temperature congenial and agrecable to them, since it is a general observation among gardeners, that when the mulberry-tree legins to expand its foliage, it is a cortain sign of the near approach of fine, warm, settled weather. $\Lambda$ third reason is, that the mulverry-trees may be permitted to put forth a good quantity of leaves before any of them are plucked, that so they may not suffer so much in health from being stript of their foliage as they other'wise would do, and may be equal to the support of a much larger stock of insects. For it is certain, that the leaves are as necessary to the life of a vegetable as the skin or the lungs are to that of an animal. If, therefore, most of the young leares are immediately cropped off as soon as they 


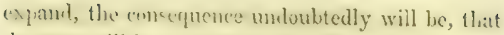
the tree will ha su hakwat and retarded in put. ting forth it: leaves, that it will not produce neat the quantity it otherwive would have deme, and, if this usage is often repented, will ultimately be destroyed.

Comsidemalle mins have been taken to rear the Silkworm, and to encoumige the manufacture, at l'erlac, a smatl twwn of thatehed houses in Lower. II liands of the groprictors of the island, but the comitatus has now purhased it. The : Bill:woms are reared lyy the featante, who bing the curoms to Perlar, where they are paid for them by the agent of the cominatus. Nulberry-trees, which have been plunted as the common property of the neighhourhoud, grow on each side of many of the road. ITron the whole, huwever, the cultiration of Silkworms does not flonrish. The quantity of cucoons has sometimes anominted to fifty centners, which yield, under jroper managemeit, about one-ninth part of good silk; but eren this is abore the present produce.

Many attempts made in other parts of Hungary to rear these insects have been attended with some suceess. They were first introduced into the Banat by Count Merey, about the year 173.1; but the 'l'urkish war breaking out in 1739, forced him (t) relinquish the prusuit. In 1765 , the Empress Maria

VOI. II. 
Theresa did her utmost to encourage the culture; and afterwards the Emperor Juseph constructed buildings for the purpose, planted mulberry-trees, brought Italians into the country who had been accustomed to the managenent of the worms and their silk, and cndeavoured to encourage the peasants to rear them in their own cottages. By these means the produce of silk was so much increased, that $\mathrm{Hun}$ gary, which, in 1765, yiclded but 183 pfimds of wound silk, produced, in 1785 , not less than 13,100 pfunds. 'This branch of industry has not, however, procecded so rapidly since that time; and thegreatest ycarly produce which has been known was in 1801 , when the royal silk establishment produced 178 centners, and those of private individuals probably about 30 centners. By far the greater part of it comes from districts of the military frontiers, extending along the south of IIungary. The culture of the Silkworm is not, however, confined to these limits, lut private establishments, loth for rearing the worms and purchasing the cocoons from the peasants, are found in the Biharer, Bekeser, Pesther, Heveser, WVeszprimer, and Neutraer counties, and in the towns of Lombor and Tymau.

In the year 1802, Joseph Blaschkowitsch, who had devoted attention to the sulject, invited the landholders to witness a trial, instituted under the encouragement of government at Ofen, of his improved method of rearing the Silkworm. The great 
ubjects he proposed were to diminish the time that clapses between the hatching of the egg and the obtaining of the pure silk, so that it might not interfere with the occupations of the agriculturist. and he found he could reduce this period from nine to fire wecks. He likewise found means to feed the worms, produced from half an ounce of the eggs, unon the leaves of six mulberry-trees, which before had required from twenty to twenty-six. From every half ounce of eggs he procured fifteen or twenty pfinds of cocoons more than by the usual process; and from eight to ten pfunds of cocoons he obtained one pfund of pure silk, whereas twenty or thirty pfunds had formerly been necessary for the same produce: This method farther enabled a peasant, who could before mamage only half an sunce of eggs, now to rear the worms from half a pfunt. The means which he employed were chiefly intended to reduce each different process in the eventful lives of these little animals to a regular period, that every one might run his course as nearly as possible within the same time. With this view, he discarded most of the artificial methods which had been adopted for hatching the egg, and. without exposing them to the partial heat of the sum, to wamed pillows, or to the warmth of the hosom, all of which were practised, placed them in a situation where they might be equally affected on all sides by the surrounding atmosphere. He in. 
troduced the use of seed mats, which he found. in many respects, stperior to japer, for receiving tho eggs; and as all the cocoons were finished together, he was able to deatroy all the chrysalids at the same time. For this purpose, lie constructed an oven in which he killed the animals in thirty centners of ecoons in twenty-four lours, and on his invention could speak with confidence as to the periods of the changes, in the following terms:-" On the 12th of May the worms will begin to hreak from their eggs; seven days afterwards the first change of the skin will take flace, which will occupy twenty-four hours; at the end of another week, the second cliange of the skin will commence, which will last for two emmylete days; seven days afterwards the thivel change will oceur, which will oceupy three days; and in seren days more they will ehange their skin for the fourth and last time, a process which will continue for four lays. In eiglit days from this time the whole of the Silkworms will hegin to spin; in five days more their lahours will be completed; so that, on the sixth day, they may be taken fiom the places where they have spun, and exposed a day before the winding commences."

Blasehlowitseh aftorwarls published some books of much authority on the subject. In 180\%, an establishment was instituted at lioth Almus, near Pesth, which was put under his govidaner ; and, in 
1812, Stephen Von Begh, Olergespaun of the 13aranga comitatus, brought him to Fünfkirchen to give instructions "jon the sulject publicly, which he did with great eflect, and seemed at the time to infuse much ardour into thuse he taught.

The greatest attention was pair to this subject in the Banat and the military frontier provinees, where the peculiarity of the constitution, as a military government, gives a singular facility to authoritative interferenec; and the fullowing alsstract of the: regrulations, issucd in 180.5 , presents an illustration by no means devoid of interest, of the mole in which that interference is direeted.

In order to give greater spirit to the culture of silk in the district of the frontier Banat regiment, by the practical education of scholars, the general frontier direction, after deliberation with the masters of the schools, commanded that the holydays, which lat hitherto been kept in the months of september and October, should, in future, lo transferred to the months of May and June, and that, luring them, the scholars should be employed in the managenent of the Silkworms, under the inspection of a teacher ; one-lalf of the profits to be given to the teacters and their assistants, and the other half to the scholars who applied themselves diligently to the pursuit ; amongst whom, the fur who must exedled were to receive double shares. J'he stands upon which they kept silkworms were, in the first jlace, to he 
paid for by the government, and afterwards to be kept in repair out of the profits. In addition to the extensive mulberry plantations which already existed, all other open places, particularly the churchyards, were to be planted with these trees; and to every person who employed himself in rearing Silkworms a certain number of trees was to be assigned.

The gathering of the leaves was first to be performed by the scholars, under the inspection of their superiors. Whosocver intentionally injured a mulberry-tree was called upon to plant fifteen, and to be answerable for their growing. According to an order issued in the preceding year, the inhabitants of the frontier regimental districts were obliged to make good the decayed mulberry-trees, by means of new plants, and were, in a particular manner, directed to take one of the mulberry plantations. By means of these and similar ordinances, the progress, both as to the quality of silk produced, and as to the number of mulberry-trees, was very considerable. In October 1806, it was found that, in the southern military frontiers, without including those of Transylvania, which are more to the east, there were 706,731 trees of this species, making an increase, during the last year, of 17,929. Proper officers were appointed for the inspection of all the different processes, both in the culture of the mulberry, and in the rearing of the worms, and the 
most approved books upon the subject were widely circulated.

As the result of their regulations, we find, during the three subsequent years, a rapid increase in the quantity of silk; so that the yearly produce in these military frontiers, and the sums paid by government to the cultivators, were as follows:-

In $1806,-546$ ecnt. $3 \frac{1}{2}$ pf. of cocoons, 357,44 f. $5 \frac{3}{\mathrm{k}} \mathrm{kr}$.

$$
\begin{array}{llr}
1807,-1066 & 892 \mathrm{pf} . & 918,16 \mathrm{fl} .35 \mathrm{kr} . \\
1808,-1430 & 93 ! \mathrm{pf} . & 130,912 \mathrm{fl} .53 \mathrm{~s} \mathrm{kr} .
\end{array}
$$

These were, however, the periods of its greatest success. Bad scasons followed. In 1810, the quantity was reduced to 710 centners, for which $71,705 \mathrm{fl}$. were paid; and the same cause, accompanied likewise with unfavourable political events, has given a very material check to this branch of industry, which appeared to be acquiring importance and stability. The Hungarian character, and the habits of all the peasantry of this country, are undoubtedly hut little suited to the peculiar attention and minute care which are requisite for the pursuit of an $\mathrm{cm}-$ ployment so strictly domestic; and the reward to which they can look with certainty, is hut an inadequate return for the labour and restraint to which they are suljected. The government has not, indeed, a monopoly in this article: the market is open to any private speculator; still but few purchasers offer themselves, and the peasant is generally obliged 
(1) be contented with the rate fixed at the royal establishments, where he receives from thirty kreutzers to a gilder for a pfund of cocoons, aceording to the state in which they are brought.

In the year 1810, the Ritter Von Ifecinth instituted trials in the Banat military frontier, under the countenanee of govermment, with a view to naturalize the Silkworm in the open air; and the followirg account, written by one who bore fart in these attempts, will be read with interest :-

"In pursuance of the orders of the commandantgeneral, of 27 th June 1810 , ly which the agricultural officers of this district were reguired to make experiments, under the direction of the Jitter Von Heinth, with a view to accustom the fill:wom to the climate of the country, trials were actually mate during the last spring in the following places:- At lorlasvaros, with one loth (half ounce) of encrs; at Thomashaez, with one half loth; at Oppovat, with one loth ; at (ilogenn, with one loth; at Jerkovacz, with one Jmelf loth; at Alimmar, with one loth ; at Kubin, witlı one half luth; at (irelueniez, with one laalf loth; at lshistie, with one half loth; at Neudorf, with one half loth; at I'ansenva, with several loths, both on single trees, and in the mulberry plantations.

"The weather proving finc, line cyrss, at the end of $A$ pril and the herinning of Nay, were fastened in boxes secured with a enver upon the trees, ant 
fiecly exposed to the sun. As the weather varied a little in different places, the erres were not hatched exactly at the same time; but where much rain and considerable changes in the atmosphere oceured, the worms begin to aplear on the 10 th or 12 th day, which was the ease with ahmost all that were put ont in April. Where the weather was fine and dry, they crept out upon the fifth day. $\Lambda$ s som as this hat talien place, the covers of the boxes were removed, the nearest branches of the trees were bent down into the hoses, and an opportunity was thus given to the little anmals of seeking their own nourishoment, and of distriluting themedves gradually over the trees.

"At Jerkovacz, Thomashevaez, Alibunar, and Neudorf, in the north-eastem part of this flat district, the little race was in a short time completely destroyed by storms and sudden showers. In other places they attained to diflerent sizes, according as the atmosploce was more or less disturbed. They had alrcally passed through their first sleep at Glogon, l'orlasvaris, and Islistic, and even through their second at Grebenie\%, when hail storms, showers, and gusts of wind, cast them down from the leaves, and they perished.

" $\Delta$ t Humplie\%, Oplovi, Staresora, Kubin, and l'anscova, in the south, where no hail fell, the Silkworms survired till the period of spinning, without being injured by the castal rains of the cold nights 
frequent in that district; but hard showers washed down many of the large and heary worms. Other dangers also threatened the destruction of these little colonies_dangers which increased with their growth, and will remain as obstacles to the culture of the silk in the open air, even though the difficulties of the climate should be overcome. Birds, particularly sparrows and starlings, killed a great number; and others, as they approached the period of spinning, fell from the trees, and were crushed. It is only at Oppova, Starcsova, and Panscova, that a fow actually spun. At Oppova thirty-one came to perfection, and fifteen male and sixteen female moths ate through their cones; six only of the former and three of the latter had strength enough to come forth, and then laid eggs upon their cocoons, which in time produced other Silkworms, which died. At Staresova, one cocoon only was found. The worns at Panscova, which were placed upon the trees by the wayside and in the plantations, suffered the same fate as the rest. The birds destroyed the greater part ; others were washed away by the rain; the rest, for most part, when they had undergone their second change of skin, fell to the ground by their own weight, where they were crushed, or lay quite unable to assist themsclves. On the thick espaliers in the plantation, they were, in every respect, the most secure, as they were less exposed to the wind and birds. The fall from the lower leaves was less dangerous, and recovery 
easier. Here many worms came to perfection, spun, crept from their cocoons, and, in twenty-four different places, eggs were deposited; the moths laid their eggs thickly together in irregular forms, never upon the leaves, but upon the bark of the trunks or the branches.

"From these trials, it appears that the climate does not of itself prevent the eggs from hatehing, and that an ordinary rain, even of some duration, and the coolness of the nights, are not injurious to the worms; but it is certain, that the longer they are, and the more heary they become, the more helpless they appear; and that, on account of the little power they possess of attaching themsclves firmly to the trees, when compared with other animals of a similar kind, they are badly protected, and fall very frequently to the ground, It will be seen, whether the insects, procured from eggs laid in the open air, possess greater power of lholding themselves on the trees, provided the eggs are not destroyed by the weather, or by ants, before the spring arrives."

Such is the disastrous history of this tender colony; and those which were established in the Walacho-Illyrian frontier shared nearly the same fatc. The trials were repeated in 1812, and prover equally unsuccessful.

Austria has long been celehrated for its manufacture of silks. Of the richest silks, the museum of Vienna boasts a large variety ; but this manufizcture, 
once so flourishing, was almost totally destroyed l,y the efiects of war. Before the l'rench lievolution, it employed, at Vienna alone, six thousand loums. In 1803, it was reduced nearly one-thirel. In 1814 , many establishments had been given uj, and others were on the decline. Since which time, it has again assumed more importance, although it is believed it will never reteh its former state. Mamy mest beautiful articles of rich embroidered silk are to be found in the palates of the wealthy, or the musem of the Emperor ; but this faltric has been discontinued, and the looms, since $181 \%$, have ben chiefly employed in weaving shitwls, to which all the females of the capitalcontinue to give great encouragement. Vienna is the chief, hut not the only, seat of silk manufacture in $\Lambda$ ustriil, other principal towns participating to a small extent.

The White Silkworm of China las been successfully intruduced into Mureia in Spain, a provinee which is farvumbly situated for the cultivation of that insect: its southem boundaries being the Mecliterranean, and presenting a salubrious climate. The produce of this species is superior, both in quantity and quality, to that from the common worms. This important improvement is due to the zeal of Don Thomas Serrano, who, after a life devoted to the happiness of his country, was furced to seck, at Gibraltar, an asylum against the persecutions of the servile factions. 
Many efforts have been reently made to introduce the Silkworm, on an extensive scale, into Ircland. These, however, do not appear to have been sucessful, which must be attributed to some mismanagement in the treatment of the animal, and other circumstances; for we consider the climate much better adapted, then that of the sister island, for the breeding of this animal. Wre have no doubt, but if still persevered in, it might ultimately prove of great and extensive benefit to the peasantry of that country. As we have before hinted, it is our firn belief, that in time the insect might beeome natural ized to this latitude, under the guidance and fostering care of man. For we have seen in the higher animals, that they have been brought by degrees to breed and thrive in our island, although the temperature is widely different from that of their own.

Lord Kingston, with the most patriotic zcal, used every effurt to propagate the worm, and benefit his native land; but in his efforts he has not been assisted. In the year 182\%, that nobleman had upwards of therty thonesand mulbery-trees growing upon his estates in Ireland, and these in the most flourishing and healthy condition. He had sent to market in 1830 a considerable quantity of raw silk, of the best quality. But, we fear, the restless genius of the peasantry is ill adapted for an employment, where assiduity and careful attention are resuired. 
In this opinion, we think we are borne out hy the fate which has attended the manufictories of cotton lace. The low price of labour induced a belief that these might be sucecssfully cultivated; lnut a comlination of eireumstances has blighted the hopes of llse public-spirited individuals who introduced them. IVe hope that still their may be found patriots to persevere, and gain an ascendency over prejudice. The cultivation of the Silkworm and the growing of flax, if pursued with vigour, might yet render Ireland prosperous and happy.

Very lately, a remarkable phenomenon presented itself in Ireland, which goes far to support our upinions. A voluntary colony of Silkworms settled on the demesne of Mount Loftus, county of Cork, the seat of Sir Nicholas Loftus, Baronet. On this demesne, there are no mulberry-trees; but there are several of the European spindle-tree, or Euonymus Europens; and of these the insect colonists took possession. One tree was literally weighed down with them; and it was supposed there could not be less than half a million of worms actively spimning their cones upon it. This remarkable circumstance is well worthy the attention of naturalists, as it proves, that the Silkworm may exist and thrive upon another tree than the mulberry. Those at Mount Loftus are said to have heen in vigorous loalth, and to have produced excellent silk. 
'Time alone can prove what may be the result of feeding these caterpillars on the spindle-tree. Till then we must suppose that the mulbery is the true tood of the Silkworm; and will finish our account of this highly useful insect hy an account of that tree. 


\section{ON THE CULTIVATION OF THE MULBERRY-TREE.}

From all we have above narrated, it is quite cvident, that the first step towards the successful propragation of the Silkworm, is the extensive cultivation of the mulberry-trec. It is the Morus of botanists, $-a$ genus of the order Tetrandrio, of which there are seven distinct species, namely, the Nigra, or black fruited; the Alla, or white fruited; the Rubra, or red Virginian; the Tartarica, or 'Tartarian; the P'ap!yfera, or paper mulberry of Japan, from which paper is manufictured in that country,-now successfully used in France for feeding Silkworms. The Tinctoria and Indica are not used for feeling Silkworms.

All the species of mulberry are hardy, and easily cultivated and naturalized in any climate. They are rapid in their growth, and abundant in their foliage. 
For cold climates it has been found that the black is the best adapted; and, besides, it has another advantage,- that of produeing nearly double the quantity of leaves to those of other species. Although the mulbery grows with much vigour in moist lands, it has been found that these produced in such situations are not so nutritious to the worms, in whose constitution they induce a weakness. Hence it is found, that although in thy soils the foilage is less abundant, the recuction in quantity is amply compensated by the additional nutriment which they afford, and the consequent fincr quality and eren additional quantity of the silk produced.

The mulberry-tree ean be easily raised either from cuttings, layers, or sceds. The plan arlopted in France for raising plauts from seeds is curious, as will appear from the following deseriptinn:- "Take the ripe herries when they are full of juice and seeds. Next take a rough horsehair line, or rope, such as we dry linen on, with a good handful of ripe mulberries; run your hand along the line, bruising the berrics, and mashing them as much as possible, as your hand runs along, so that the pulp and seed of the berries may adhere in great abundanee to the rope, or line. Next dig a trench in the ground where you wish to plant them, much like what is practised in kitehen gardens in England for crops of various kinds. Next cut the rope, or hair line, into lengths, according to the length of the trench you think fit to 
make, and plunge the line, full of mashed berries, into the trench; then cover it well over with earth, always remembering afterwards to water it plentifully, which is indespensable to success. The sceds of the berries thus sown will grow, and soon shoot out suckers which will bear young leaves, and these are considered the best fur the fuod of the Silkwom. The fueility and rapidity with which young leaves may by this means be produced is evident ; for you can fill as many rows of trenches in this way as are required, and it can never be necessary to have mulberry-trees ligher than our rasplerry, currant, or gooseberry bushes. Whenever they get beyond that height they lose their value; and if these branches succed, you may have a supply coming fresh up day after day, or any quantity you please."

In climates of a similar temperature with that of Great Britain, seedlings will seldom reach above three inches in height during the first year. It is different however, in castern countries where these seedlings are mounded, in the succeeding, for feeding the Silkworms; and a second crop is in like manner cut for the food to a second brood of caterpillars. Those experienced in the culture of Silkworms can readily recognise the silk produced by caterpillars fed on these young shoots, from the superiority of its texture. Those fed on the leaves of the mature mulbery, always produce an inferior quality of silk. 
The most simple and speedy method of producing mulberry plants, is from cuttings ; they are always more rapid in their growtl, and stronger. But this is most sucecssfully practised in moist climates.

The Chinese never allow mulberry-trees to grow above the height to which a man can reach. They carefully cut out the main central stem, and allow the side branches to expand in all directions, taking eare to prume them when they show signs of growing high. Besides, they always eut the centre of the tree into a hollow cylinder, into which the person who pulls the leaves enters, and removes them, without damaging the trees.

It has been ascertained that the true mode of producing the most abundant crop of leaves, is to deprive the tree of all its strong and leading stems. In Tuseany considerable attention has been paid to the cultiration of the trees; and M. Nollet says the inhalitants of these provinees, particularly in Florence, do not cultivate half the number of trees which are raised in Piedmont, in proportion to the number of Silkworms which are reared, and the quantity of silk produced by them. This plan of saving, is in conserunence of their causing the caterfillars to be hatehed at two different seasons; the first in spring, and the second, after the first have spun their cones. In the Isle of France, M. Chazel reared three generations of eaterpillars between 
December and May. Whereas in Italy, it is the opinion of Count 1)andolo, that the mulberry-tree cannot be twice stripped of its leaves without injuring the trees; and he alleges, that one good crop of silk is worth more than both the first and second; and that the quality of the second crop is always inferior.

That the Silkworm caterpillar may arrive at its complete state of development, the quantity of leares which they necessarily consume must bear a relation to their quantity of nutrition. The better the quality of the leaves, less will be required for this purpose, and the animal liable to less fatigue in mastienting them; so that saceliarine substance, unless combined with resinous matter in a duc proportion, may feed the animal, but will never cnable it to produce silk proportionate to its weight.

In various parts of France and Italy, many persons rear Silkworms, who have no means of supplying them with food, exeept by the purchase of mulbery leaves, which are brought to the market, and sold by weight. It therefore requires not only judgment, but experience, to enable the purchaser to distinguish such as are most nutritive.

Great care must be taken to prevent the leaves from heating, and therelyy producing the first stage of fermentation, which destroys their quality, and n'oves too stimulating for the Silkwomms; and they 
should also be presented to the aminals in a perfectly dry state, otherwise contagious and other fatal diseases will ensue.

It is a remarkable fict, that no other insect whatever but the Silkworm feeds upon the mulberrytree. Various caterpillars have been put on the leaves of mulberry-trees, but they have always been found to reject them. Even the Aphides, some species of which are found on almost every other plant, have never been discovered on this tree.

END OF VOLUME SECOND.

DINAUIRGH :

FHINTED BY ҰY. AITKEN, 1, BT. JAMES'S SOUARE. 







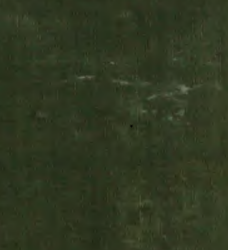